\title{
Geology, surface hydrology, and fish habitat relationships in the upper Shavers Fork drainage basin, West Virginia
}

\author{
Ryan Cooley Gaujot \\ West Virginia University
}

Follow this and additional works at: https://researchrepository.wvu.edu/etd

\section{Recommended Citation}

Gaujot, Ryan Cooley, "Geology, surface hydrology, and fish habitat relationships in the upper Shavers Fork drainage basin, West Virginia" (2002). Graduate Theses, Dissertations, and Problem Reports. 1461. https://researchrepository.wvu.edu/etd/1461

This Thesis is protected by copyright and/or related rights. It has been brought to you by the The Research Repository @ WVU with permission from the rights-holder(s). You are free to use this Thesis in any way that is permitted by the copyright and related rights legislation that applies to your use. For other uses you must obtain permission from the rights-holder(s) directly, unless additional rights are indicated by a Creative Commons license in the record and/ or on the work itself. This Thesis has been accepted for inclusion in WVU Graduate Theses, Dissertations, and Problem Reports collection by an authorized administrator of The Research Repository @ WVU. For more information, please contact researchrepository@mail.wvu.edu. 
Geology, Surface Hydrology, and Fish Habitat Relationships in the upper Shavers Fork Drainage Basin, West Virginia

Ryan Cooley Gaujot

\author{
Thesis submitted to the \\ Eberly College of Arts and Sciences \\ at West Virginia University \\ in partial fulfillment of the requirements \\ for the degree of
}

Master of Science

In

Geology

Thesis Committee:

J. Steven Kite, Ph.D. (Chair)

J. Todd Petty, Ph.D.

Robert E. Behling, Ph.D.

Department of Geology and Geography

Morgantown, West Virginia

2002

Keywords: Fluvial Geomorphology, Salvenilus fontinalis, Channel Units 


\section{Abstract \\ Geology, Surface Hydrology, and Fish Habitat Relationships in the upper Shavers Fork Drainage Basin, West Virginia Ryan Cooley Gaujot}

Shavers Fork is the mainstem stream of a unique upper elevation watershed located in the Appalachian Plateaus province of West Virginia. The continuous trellis drainage generally exhibits a C3 Rosgen-type stream classification. Surficial "facies" mapping of in-stream and floodplain-adjacent landforms helped to classify small-scale flow patterns into heterogeneous and homogeneous channel units. Channel-unit bankfull width, channel-unit length, channel-unit area, and channel-unit depth all increase in the downstream direction. Riffles constitute 32 percent of the total channel unit area, riffle-run complexes and glides make up 26 percent each, bluff-pool complexes constitute 7 percent, riffle-glide complexes 6 percent, and true pools make up only 2 percent. Upper reaches contain the most in-stream and riparian heterogeneity and the highest relative abundance of large woody debris (LWD).

In-stream heterogeneity dominates pools and channel-unit complexes, which comprise 69 percent of the total stream area. In-stream homogeneity dominates riffles and glides which constitute 31 percent of the total stream area. Homogeneous channel units below Second Fork and stream reaches that come in contact with the railroad bed are potential target areas for remediation.

Restoration of a streamside canopy, particularly near the railroad bed, would mitigate large in-stream temperature fluctuations and rehabilitate the lotic system. 


\section{Acknowledgments}

Thanks to the following groups and individuals without whose support this research could not have been done: the West Virginia Division of Natural Resources, the United States Fish and Wildlife Service, the United States Forest Service, Trout Unlimited, and the United States Geological Survey for the funding which made this research possible; the West Virginia University Department of Geology and Geography and Division of Forestry for supplying me with the knowledge and tools to accomplish this research; and the members of my committee: Dr. J. Steven Kite, Dr. J. Todd Petty, and Dr. Robert E. Behling. Thanks to all who provided field work, reviews, valuable discussion and guidance: Jocelyn Smith, Laura Sheehan, Brian Kwak, Matt Fanny, Jeff Hansbarger, J esse Bopp, Peter Lamothe, Pat Masik, Dan Campbell, George Constantz, Bekki Leigh, Ron Preston, Jim Rawson, Bill Thorne, Bryan Moore, Steve Brown, Walter Kordek, J oel Harrison, Danny Bennett, and Mike Shingleton. Thanks to all who provided computer and cartographic assistance: the Canaan Valley Institute, Randy Crowe, and the West Virginia University GIS Technology Center staff, including J ackie Snyder, Kurt Donaldson, and J esse Rouse. Special thanks are given to my Mom, Dad, Todd, Moses, J ake, and especially Cass, for giving me the courage, persistence, motivation, and determination to achieve. 
Table of Contents

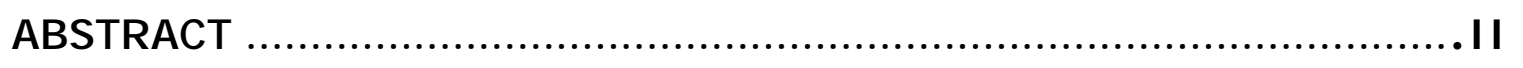

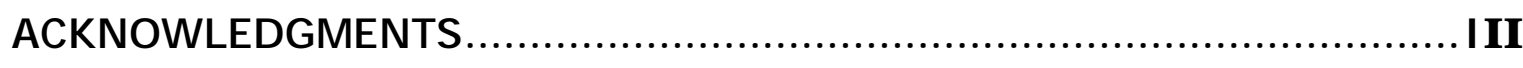

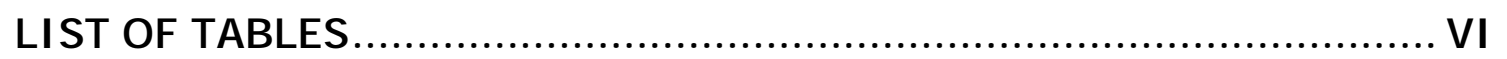

LIST OF FI GURES ................................................................. VI I

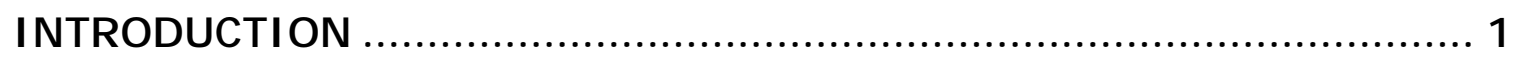

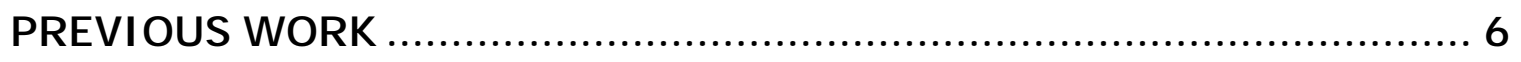

PURPOSE AND OBJ ECTI VES .......................................................... 8

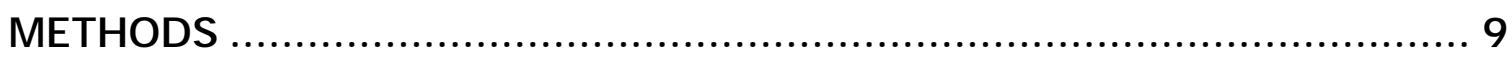

Scale Selection ...................................................................... 10

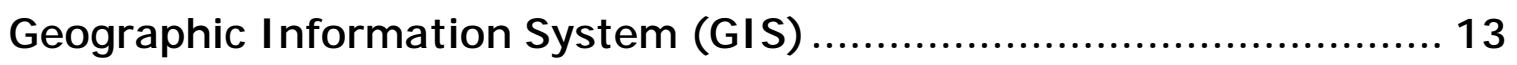

Field Data Acquisition ..................................................................... 13

Basinwide Visual Estimation Technique ........................................ 14

Global Positioning System (GPS) ................................................. 15

A Four-Fold Surficial Geology Mapping Method ............................... 15

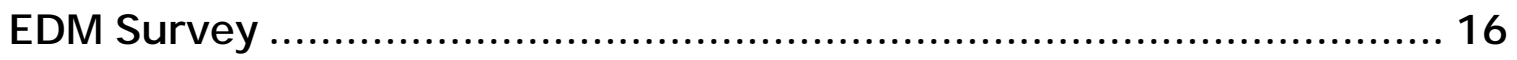

PHYSI OGRAPHY, CLI MATE, AND SOI LS OF SHAVERS FORK ............... 17

LAND USE HISTORY AND I MPACTS TO SHAVERS FORK........................ 18

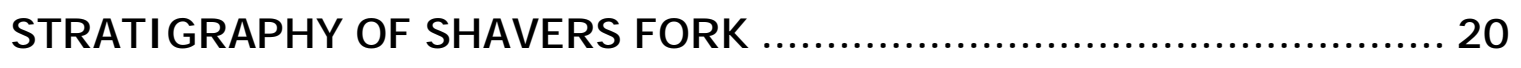

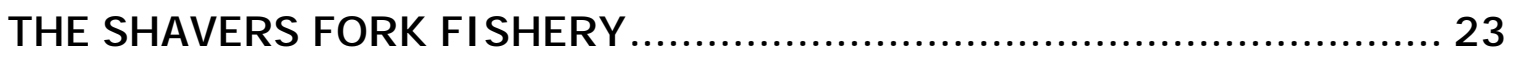

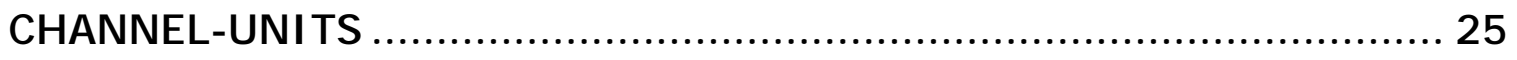


PoOls.................................................................................... 27

Glides.

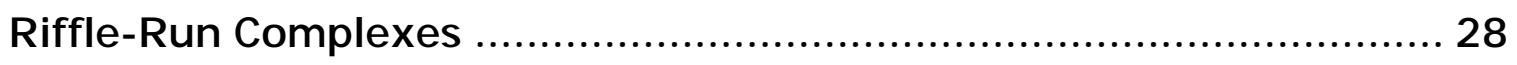

Riffle-Glide Complexes....................................................................... 29

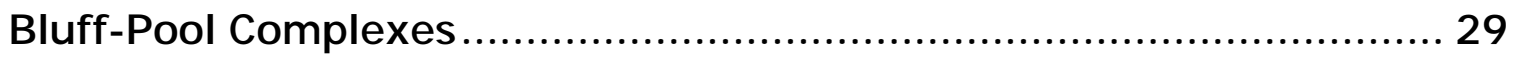

RESULTS .................................................................................... 31

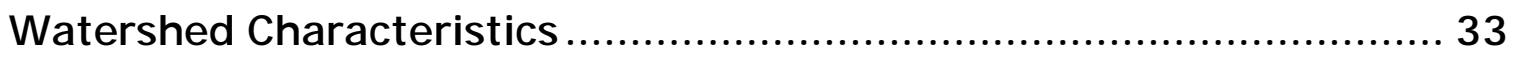

Channel Unit Results............................................................... 34

Bankfull Width ................................................................................. 35

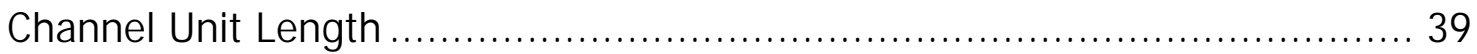

Channel Unit Area ........................................................................ 43

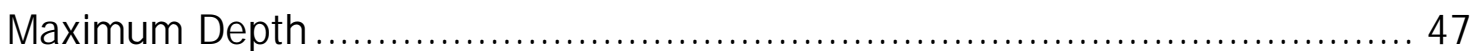

Channel Unit Proportion ........................................................................ 51

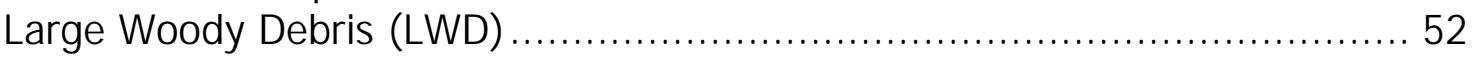

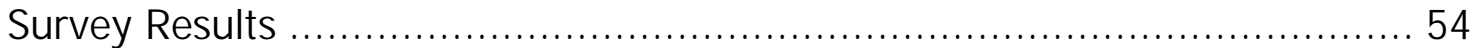

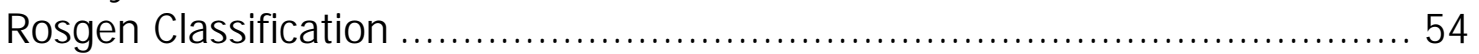

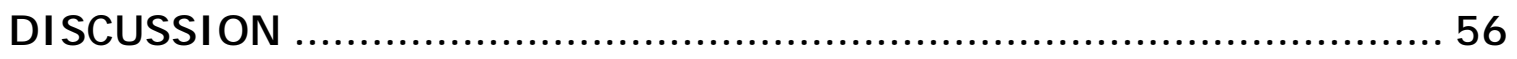

Morphologic Disequilibria ............................................................. 56

Channel Unit Disconformities .......................................................... 58

Remediation Suggestions ................................................................. 59

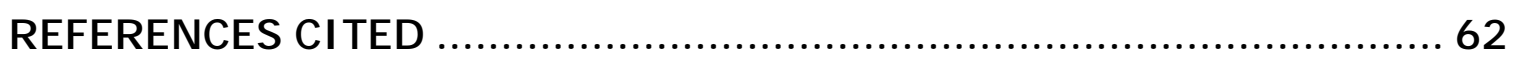

ADDI TI ONAL BI BLI OGRAPHY ........................................................... 65

APPENDI X I ...................................................................................... 70

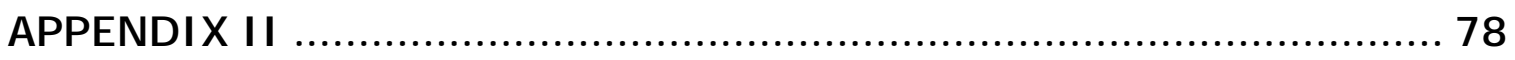




\section{List of Tables}

Table 1: The members of a Shavers Fork cooperative unit indicating research emphasis and program.

Table 2: A list of field data collection dates, activities, and the corresponding daily stage from the Cheat Bridge gauging station \#3067510.

Table 3: An application of the four-fold mapping method developed by Kite (1996) categorizing the inventoried morphologic features of Shavers Fork.

Table 4: A table of the bedrock stratigraphy that comprise the upper Shavers Fork field area and descriptions of each geologic unit.

Table 5: A description of measurements and estimates involving the BVET calibration ratio.

Table 6: Channel unit means and standard deviations for bankfull width, length, area, and maximum depth.

Appendix I: A table of channel unit data listed from Spruce to Lambert Run in the downstream direction.

Appendix II : A table of data corresponding to the occurrence of large woody debris (LWD). 


\section{List of Figures}

Figure 1: A map of West Virginia showing the Cheat Watershed and the upper Shavers Fork field area.

Figure 2: The Shavers Fork field area's geographical and elevational relationship to the entire Cheat Watershed.

Figure 3: A topographic DRG image of the mapped extent of Shavers Fork.

Figure 4: A DOQQ map of Snowshoe and Silver Creek Ski Resorts showing the proximity to Spruce.

Figure 5: A geologic map of the field area.

Figure 6: A DOQQ map of Shavers Fork indicating the boundaries of the geology and channel unit mapping and the location of the Black Run survey.

Figure 7: Elevation changes with horizontal distance from Thorny Flat to Lambert Run.

Figure 8: Graph of bankfull width for all 393-channel units from Spruce to Lambert Run.

Figure 9: Graph of calibrated bankfull channel width verses distance for riffles.

Figure 10: Graph of calibrated bankfull channel width verses distance for pools.

Figure 11: Graph of calibrated bankfull channel width verses distance for glides. 
Figure 12: Graph of calibrated bankfull channel width verses distance for rifflerun complexes.

Figure 13: Graph of calibrated bankfull channel width verses distance for riffleglide complexes.

Figure 14: Graph of calibrated bankfull channel width verses distance for bluffpool complexes.

Figure 15: Graph of channel unit length verses distance for all 393-channel units from Spruce to Lambert Run.

Figure 16: Graph of channel unit length verses distance for riffles from Spruce to Lambert Run.

Figure 17: Graph of channel unit length verses distance for pools from Spruce to Lambert Run.

Figure 18: Graph of channel unit length verses distance for glides from Spruce to Lambert Run.

Figure 19: Graph of channel unit length verses distance for riffle-run complexes from Spruce to Lambert Run.

Figure 20: Graph of channel unit length verses distance for riffle-glide complexes from Spruce to Lambert Run.

Figure 21: Graph of channel unit length verses distance for bluff-pool complexes from Spruce to Lambert Run.

Figure 22: Graph channel unit area verses distance for 393 channel units from Spruce to Lambert Run. 
Figure 23: Graph channel unit area verses distance for riffles from Spruce to Lambert Run.

Figure 24: Graph channel unit area verses distance for pools from Spruce to Lambert Run.

Figure 25: Graph channel unit area verses distance for glides from Spruce to Lambert Run.

Figure 26: Graph channel unit area verses distance for riffle-run complexes from Spruce to Lambert Run.

Figure 27: Graph channel unit area verses distance for riffle-glide complexes from Spruce to Lambert Run.

Figure 28: Graph channel unit area verses distance for bluff-pool complexes from Spruce to Lambert Run.

Figure 29: Graph of channel unit maximum depth verses distance for 393 channel units from Spruce to Lambert Run.

Figure 30: Graph of channel unit maximum depth verses distance for riffles from Spruce to Lambert Run.

Figure 31: Graph of channel unit maximum depth verses distance for pools from Spruce to Lambert Run.

Figure 32: Graph of channel unit maximum depth verses distance for glides from Spruce to Lambert Run.

Figure 33: Graph of channel unit maximum depth verses distance for riffle-run complexes from Spruce to Lambert Run. 
Figure 34: Graph of channel unit maximum depth verses distance for riffleglide complexes from Spruce to Lambert Run.

Figure 35: Graph of channel unit maximum depth verses distance for bluff-pool complexes from Spruce to Lambert Run.

Figure 36: The proportion of channel unit types per stream segment.

Figure 37: Plot of mean LWD per bankfull channel width for each stream segment.

Figure 38: A DOQQ map of the survey area above Black indicating the geology and channel unit boundaries.

Appendix IV: A digitization of the 72 survey points above Black Run. The map illustrates the stream boundary, alluvial bars, and profile transects of a riffle, run, pool, and glide.

Appendix V: A cross section of a riffle, run, pool, and glide showing the profile of the substrate in each channel unit 


\section{Introduction}

The Mountaineer Chapter of Trout Unlimited, in conjunction with the West Virginia Division of Natural Resources, the United States Forest Service, the United States Geological Survey, and West Virginia University, is developing an intensive, long-term management and remediation plan that addresses physical, chemical, and biological watershed characteristics important to the upper Shavers Fork native brook trout (Salvenilus fontinalis) fishery (Figure 1). The Mountaineer Chapter of Trout Unlimited adopted the $29.2 \mathrm{~km}$ (18.2 mi) headwater section of the Shavers Fork and its tributaries in May 1998 (Figure 2 and 3). University researchers comprise an interdisciplinary Shavers Fork cooperative unit (Table 1) that helps to understand the physical and biological, and chemical components of the trout fishery.

\begin{tabular}{|lll|}
\hline $\begin{array}{l}\text { Cooperative Unit Member } \\
\text { Patrcia Mazik }\end{array}$ & Emphasis & Program \\
J. Todd Petty & Fooperative Director & USGS \\
J. Steven Kite & Fluvial Geomorphology & West Virginia University \\
Robert E. Behling & Geology & West Virginia University \\
$\begin{array}{l}\text { Ryan Gaujot } \\
\text { Peter Lamothe }\end{array}$ & Fluvial Geomorphology & West Virginia University \\
Jesse Bopp & Population Dynamics & West Virginia University \\
Jeff Hansbarger & Macro Invertebrates & West Virginia University \\
& Fish Habitat Use & West Virginia University \\
& & \\
Table 1. The members of the Shavers Fork cooperative unit, indicating research \\
emphasis and program.
\end{tabular}




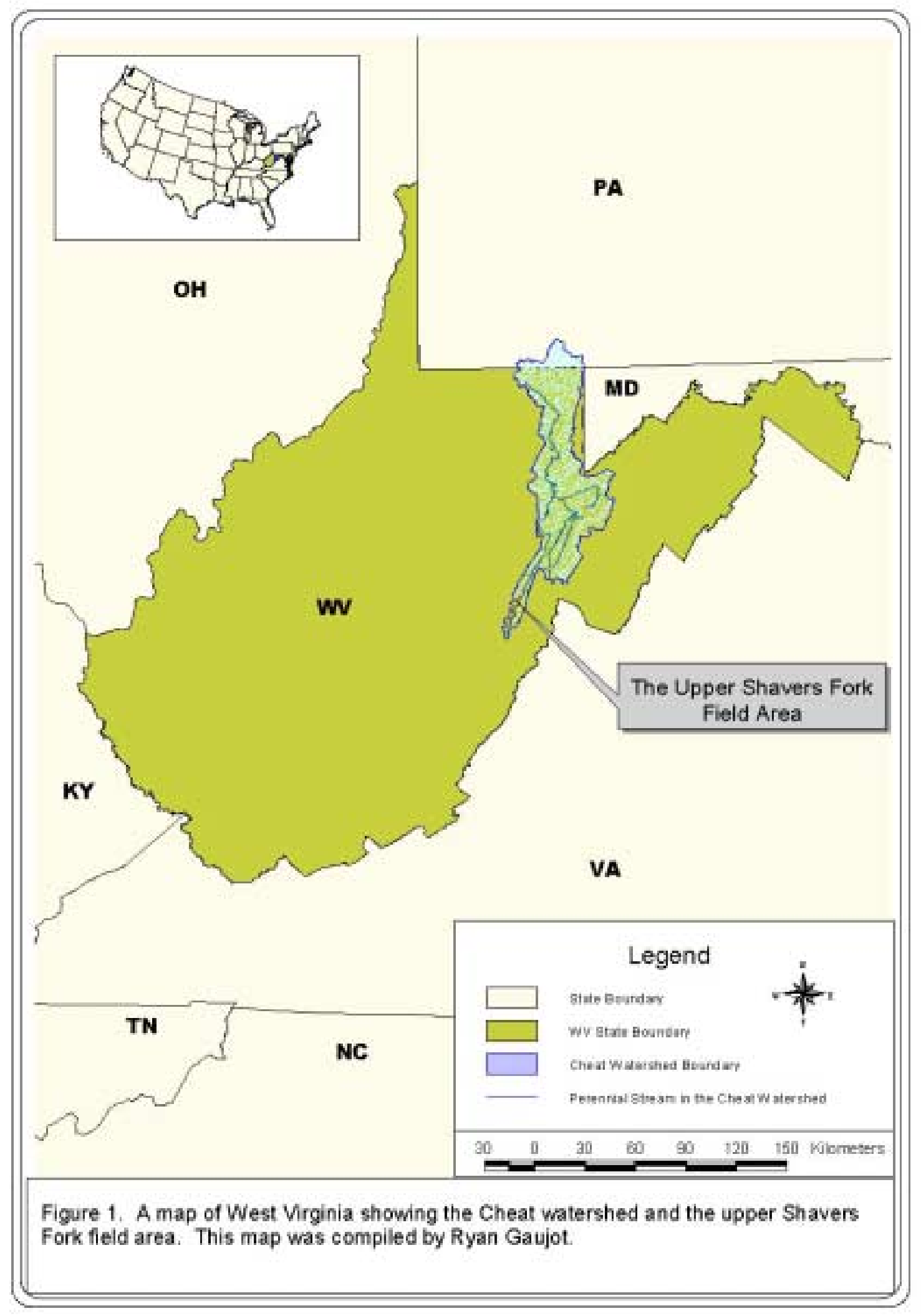




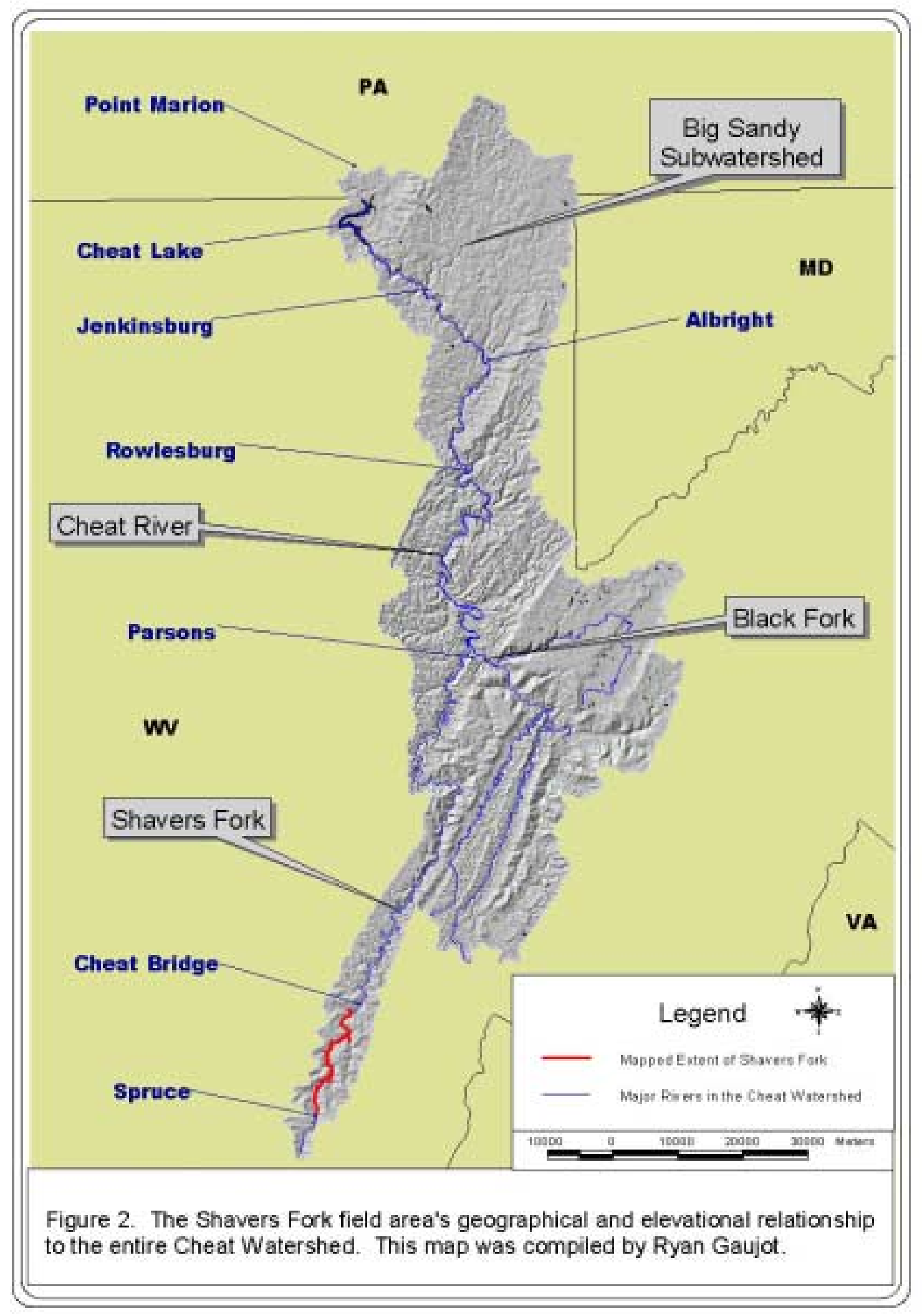




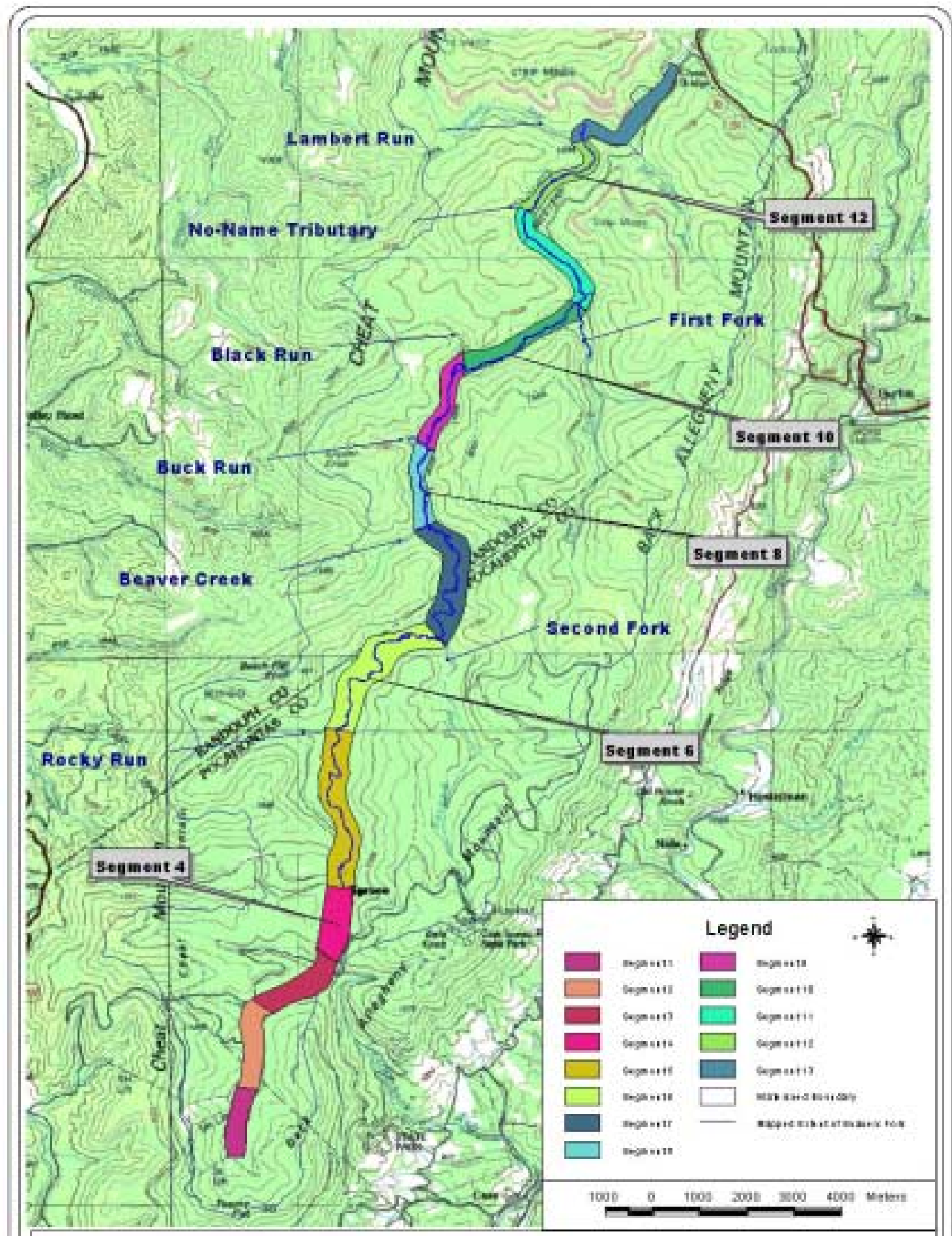

Figure 3. A DRG image of the mapped extent of Shavers Fork. This figure indicates the segment boundaries located at major tributary additions. This map was compiled by Ryan Gaujot. 
Measured and interpolated data that indicate morphological and ecological connections within the watershed will help land managers and stakeholders make decisions that optimize economic and environmental benefits for the region. The overall goal is to provide an assessment for a sustainable Shavers Fork fishery that fosters recreational opportunities and encourages an understanding of the environmental and economic values of healthy watersheds.

Shavers Fork is a major tributary to the larger Cheat Watershed and is unique in it's history, function, and form (Figure 2). The Shavers Fork landscape is dynamic, and its biological community is largely controlled by the quality and quantity of in-stream and riparian features. Research on the stream's fluvial and ecological development and historic and present-day land-use can help to describe the current state of the Shavers Fork fishery, identify what it may need to more fully reach its potential, and provide the basis for future remediation designs. The roles of this report were threefold: map and describe the physical landforms and flow types that are likely to influence fish population and community structure, indicate channel and floodplain morphologic disequilibria, and make remediation suggestions for the upper Shavers Fork watershed. The study was primarily focused on morphologic and hydraulic components of the channel. The study area was hierarchically organized into units of heterogeneous and homogeneous morphologic and hydrologic properties. The results and discussion from this research are intended to support future restoration efforts that will involve passive remediation that works with the 
stream to reestablish in-stream and riparian habitat heterogeneity and the quality habitat essential for a sustainable brook-trout fishery.

\section{Previous Work}

Hack's (1960, 1965, and 1975) dynamic equilibrium concept, developed in the central Appalachians, supplies a foundation for modern fluvial geomorphology research. Hack focused principally on the role of bedrock structure and lithology in determining landform morphology and relief. According to Hack's concept, fluvial landscapes develop by maintaining a steadystate equilibrium between driving and resisting forces (flowing water, mass wasting, and weathering) and resisting forces (strength of the bedrock and regolith). Bedrock and regolith resistance controls the position of landforms that offer suitable fish habitat, thus linking Hack's work to the research topic.

Wolman and Miller (1960) discussed the magnitude and frequency of geomorphic processes by analyzing the threshold stresses required to move available material with variations in discharge. Major flooding has occurred in areas below Cheat Bridge (Figure 2) in 1963, 1967, 1985, and 1996 (Wiley and others, 2000.) The effectiveness of processes that control landforms depends upon their frequency as well as their magnitude (Wolman and Miller, 1960). Floods of moderate magnitude that recur frequently are geomorphically more effective than rare events of unusual magnitude. Therefore, morphologic development of the floodplain and the river channel is most effective at 
discharges approximating bankfull stage (Rosgen, 1996). Bankfull stage commonly occurs during snowmelt and heavy, persistent rainfall in the Shavers Fork basin.

The river continuum concept (RCC) proposed by Vannotte and others (1980) further justifies geomorphic research on the Shavers Fork fishery. The concept asserts that the biological community in a stream is largely regulated by geomorphologic factors. RCC portrays the entire fluvial system as a continuously integrating series of physical gradients and associated biological adjustments. RCC explains how species abundance and distribution, nutrient and energy sources, and functional groups of organisms are closely tied to specific zones of a drainage system and continuously change in response to variations in underlying geology and valley form. The concept has been widely criticized with reference to the initial testing on natural, undisturbed stream systems. Cushing (1994) states, "It should be remembered that the river continuum concept was initially proposed as an idea to test, not a definitive list of predictions to which all streams would conform." Minshall (1996) later expanded the concept to include aspects of climate, geology, tributary influences, local lithology, geomorphology, and long-term human impacts. Tributary additions also have a significant effect on modifying the continuum pattern, through changes in water quality and inputs of course organic material or sediment (Minshall, 1996).

Several studies have focused on channel classification and the importance of fluvial hydraulics to ecological units (Keller and Melhorn, 1978; MacDonald, 
1991; Rabini and Jacobson, 1993; Montgomery and Buffington, 1993; Maxwell and others, 1995; Schlosser, 1995; Hayes and others, 1996). Rosgen (1994) developed a classification system for natural rivers that is widely used as an initial assessment for stream remediation efforts. Gradient, entrenchment ratio, width-depth ratio, sinuosity, channel materials, slope, and adjacent floodplain characteristics determine the general stream type in Rosgen's scheme. Most importantly, accurate bankfull discharge estimates and thalweg characteristics are crucial for obtaining the correct Rosgen-type classification and enhancing the outcome of the future remediation design. A Rosgen classification indicates morphological development characteristics that can ultimately yield a more 'natural' channel design and facilitate fish habitat remediation.

\section{Purpose and Objectives}

The purpose of this thesis is to assess the quality of brook trout habitat by mapping and classifying landscape features and flow characteristics that influence the upper Shavers Fork fishery and its remediation potential. This goal requires a contiguous fluvial geomorphological assessment of channel and floodplain components along a $24.6 \mathrm{~km}$ section of Shavers Fork, from Spruce to Lambert Run (Figure 3).

The objectives were as follows:

1. Develop a GIS-based cartographic framework for cooperative research efforts in Shavers Fork. 
2. Describe the general geology of the field area.

3. Develop a general stream-flow classification for small-scale channel units.

4. Classify stream-morphology components with reference to a four-fold surficial geology mapping method developed by Kite (1996).

5. Identify areas of morphologic disequilibria in the watershed.

a) Characterize in-stream and riparian habitat relations to channel-unit characteristics.

b) Identify and map habitat features that influence channel unit homogeneity and heterogeneity.

c) Identify and map the location of large woody debris (LWD) and assess to the total volume and influence on channel-unit heterogeneity and bank stability.

6. Suggest remediation measures for the channel, lotic system, and watershed.

\section{Methods}

To accomplish the objectives set forth in the previous section, extensive field and remotely sensed data were collected on from December 1999 to J une 2001 (Table 2). The nine study segments (4 through 12), bounded at major tributary confluences, contained 393 channel units from Spruce to Lambert Run (Figure 3). The following methodology allowed for the capture of high-resolution digital data that was displayed within a geographic information system. 


\section{Scale Selection}

Recompilation of hard copy and digital 1:24,000 scale Cass and Snyder Knob topographic maps, digital raster graphics (DRG), and digital orthophoto quarter quadrangle (DOQQ) maps provided the initial imagery of the study area. The high resolution of the digital imagery provided an invaluable tool to the field area's geography and geology.

Selection of the appropriate field map scale was the initial mapping problem facing the research. "There is no single correct scale for the study, assessment, or management of aquatic ecosystems" (Minshall, 1996). Rather, the appropriate scale depends on the scientific question being addressed. The correct map scale for the Shavers Fork research needed to incorporate a framework that resolved geomorphologic features that influence fish. Largescale of 1:5000 was found to be appropriate for resolving important habitat features. 


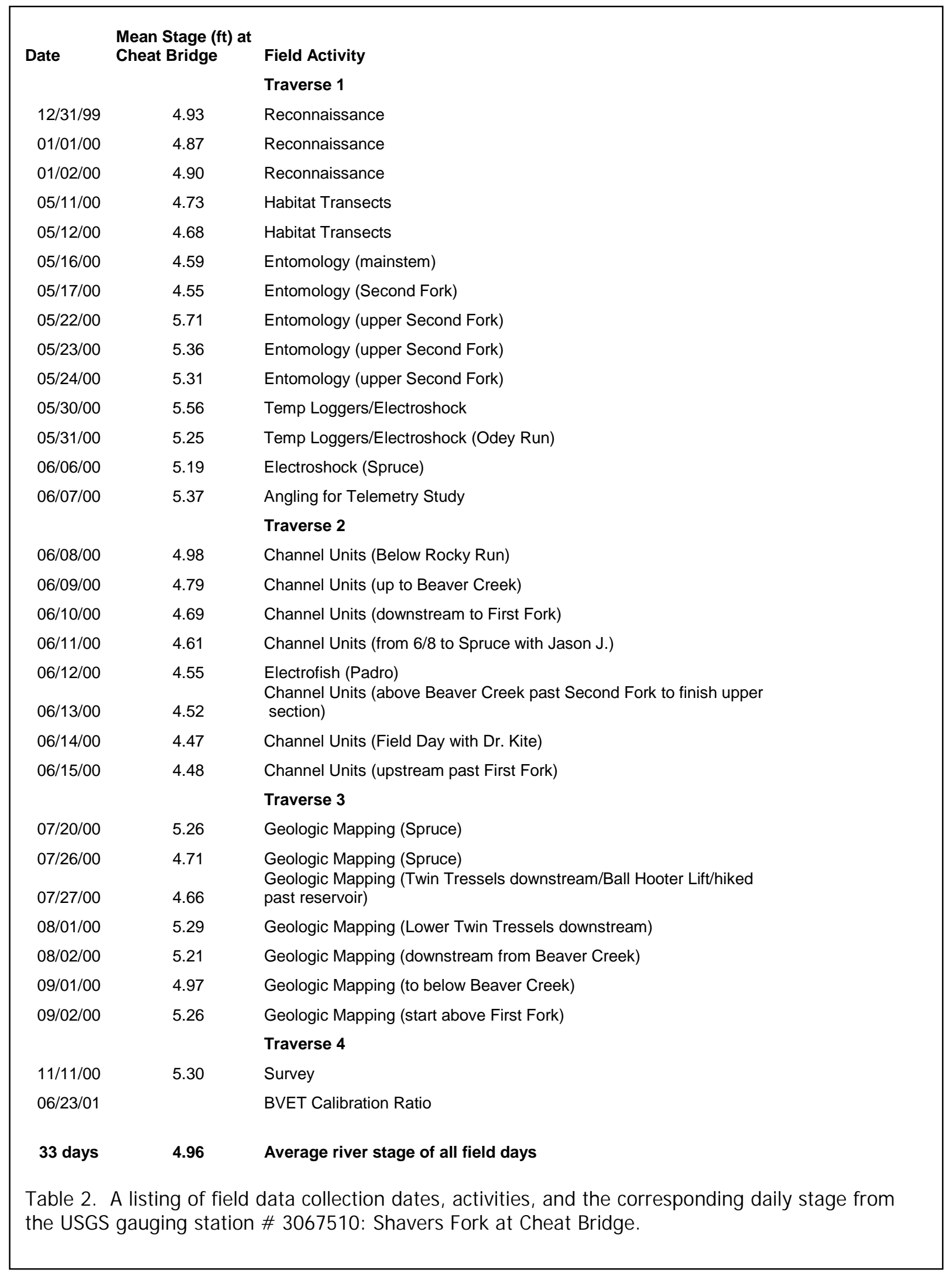


Below is an inventory of the important habitat features located, identified, inventoried, and mapped on 1:5000 DRG and DOQQ base maps:

- Stream Boundary

- Floodplain Boundary

- Alluvial Deposits

- Scour

- Bedrock Outcrops

- Boulders $>1.5 \mathrm{~m}$

- Large Woody Debris

- Intermittent Streams

- Channel Units

The perennial portion of Shavers Fork, upstream from Cheat Bridge, initially was divided into 13 segments, providing a large-scale framework for cooperative watershed efforts. Nine of the 13 segments (segment boundaries 412 on Figure 3) are located within the field area between Spruce and Lambert Run. Segments not included in the study area are 1-3, upstream of the field area boundary on Snowshoe property, and 13, downstream of the field area boundary on the Cheat Mountain Club property. The studied segments are separated by major tributary confluences with the Shavers Fork mainstem. Five of these tributaries enter Shavers Fork from the west; two tributaries enter from the east (Figure 3).

Bedrock stratigraphic sequences were not meticulously correlated, although lithologic identification of bedrock outcrops and surface landform characterization were given primary attention. The plan view orientation of the 
base maps revealed bedrock and surficial features otherwise difficult to detect while mapping in the field (Compton, 1985). Several landforms associated with timbering and mining, such as railroad grades, haul roads, and ponds, were also resolved at this scale.

Geographic Information System (GIS)

A geographic information system (GIS) provided a set of tools to store, retrieve, transform, manipulate, and display digital spatial data (Minshall, 1996). All data for this project were imported into Arc View 3.2, Arc Info 8.0, Land Desktop 2002, and Imagine Virtual GIS software programs for analysis. DRG and DOQQ images were downloaded from the West Virginia University GIS Technical Center website (www.geo.wvu.edu. DRG and DOQQ images portray 1990 and 1996 conditions respectively. These base maps efficiently capture information on topography, channel geometry, sinuosity, and distribution of instream fluvial landforms and, therefore, became the graphical foundation for the project. These maps also accurately illustrate vegetation characteristics in the riparian zone and marshlands.

Field Data Acquisition

Flow stages for Shavers Fork at Cheat Bridge were taken from 'on-line' data from the United States Geological Survey (USGS) gauge station 3067510; located in Randolph County, West Virginia ( $38^{\circ} 37^{\prime} 01^{\prime \prime}$ latitude; $79^{\circ} 52^{\prime} 12^{\prime \prime}$ 
longitude). The average stage at Cheat Bridge during field data collection was $1.51 \mathrm{~m}(4.96 \mathrm{ft})$.

Three field traverses occurred between December 1999 and November 2000 and involved walking the entire $24.6 \mathrm{~km}$ study area (Table 2). A reconnaissance exploration of the study area occurred during traverse 1. Traverse 2 involved mapping channel-units and measuring associated morphological characteristics. Traverse 3 involved mapping geomorphologic habitat features, including the surficial and bedrock geology, large woody debris (LWD), substrate and floodplain. A fourth field traverse in summer 2001 involved a check of mapping accuracy and changes in channel characteristics and large woody debris (LWD) occurrence.

\section{Basinwide Visual Estimation Technique}

Basinwide visual estimation technique (BVET) is the data collection method of visually estimating channel dimensions and characteristics. BVET techniques effectively quantify large numbers of specific habitat types important to fish. Hankin and Reeves (1988) used BVET to quantify unit areas within reaches of a stream for fish population studies. Considering the size of the Shavers Fork field area, BVET enabled the rapid collection of channel-unit and habitat data. Visually estimating bankfull width and channel-unit length yielded channel unit dimensions for the entire $24.6 \mathrm{~km}$ field area. BVET data was adjusted for error using a calibration ratio derived from measured data. Dolloff 
and others (1997) found that BVET techniques accurately reflect conditions specific to an individual stream and correctly identify uncommon habitat features that may be important to fish.

Global Positioning System (GPS)

A handheld Garmin 12XL 12-channel global positioning system (GPS) unit was used during each traverse to record Universal Transverse Mercator waypoint coordinates, based on North American Datum 1983 zone 17, and map each habitat feature's shape and location. The accuracy of the hand held-unit was approximately $10 \mathrm{~m}(\sim 30 \mathrm{ft})$ under optimal conditions. All waypoint data corresponding to in-stream features, channel geometry, channel units, and waypoints, were imported into Arc View 3.2 and Land Desktop 2000 for digital display. Waypoints helped correctly position digitized habitat polygons over base-map attributes.

\section{A Four-Fold Surficial Geology Mapping Method}

A four-fold mapping method, developed by Kite (1996), transformed the mapped geomorphic units into discrete spatial information. The mapped geomorphologic features were categorized according to their age, origin, landform, and material type (Table 3). The final GIS cartography precisely depicted geomorphic relations between mapped in-stream features and channel unit characteristics. 
EDM Survey

One representative $100 \mathrm{~m}$ reach of stream at the lower end of segment 9

(Figure 3), above Black Run, was surveyed using the Topcon TC400 electronic

distance meter (EDM). Seventy-two survey points delineated the stream

boundary, alluvium in the channel, and "below bankfull elevation" profiles of a

riffle, a run, a pool, and a glide.

\begin{tabular}{|c|c|c|c|c|c|c|c|}
\hline Map Unit Label & $\begin{array}{l}\text { Map Unit } \\
\text { Description }\end{array}$ & Age & Origin & Landform & Material & $\begin{array}{l}\text { Four-Fold } \\
\text { Identifier }\end{array}$ & Comments \\
\hline $\mathrm{Pb}$ & Point Bar & Quaternary & Alluvium & Point Bar & cobbles & $\mathrm{Q}, \mathrm{a}, \mathrm{pb}, \mathrm{c}$ & $\begin{array}{l}\text { Pb's are commonly located at the inside } \\
\text { of meander bends. }\end{array}$ \\
\hline Mcb & Mid Channel Bar & Quaternary & Alluvium & Mid Channel Bar & cobbles, boulders & $\mathrm{Q}, \mathrm{a}, \mathrm{mcb}, \mathrm{c}-\mathrm{b}$ & $\begin{array}{l}\text { Mcb's occur downstream of large } \\
\text { instream features or in wide sections of } \\
\text { the stream. }\end{array}$ \\
\hline Scour & Scour & Quaternary & Alluvium & Scour & $\begin{array}{c}\text { silt, sand, gravel, } \\
\text { cobbles }\end{array}$ & Q,a,s,si-s-g-c & $\begin{array}{l}\text { Scours locates areas of channel-bank } \\
\text { instability. }\end{array}$ \\
\hline $\mathrm{Fp}$ & Floodplain & Quaternary & Alluvium & Floodplain & sandy gravel & Q,a,flp,s-g & $\begin{array}{l}\text { Fp is the flood-prone area above } \\
\text { bankfull discharge. }\end{array}$ \\
\hline Tribdel & Tributary Delta & Quaternary & Alluvium & Tributary Delta & cobbles & $\mathrm{Q}, \mathrm{a}, \mathrm{td}, \mathrm{c}$ & $\begin{array}{l}\text { Tribdel's are located downstream of } \\
\text { tributary confluences. }\end{array}$ \\
\hline $\mathrm{IFpC}$ & $\begin{array}{l}\text { Intermittent } \\
\text { Floodplain } \\
\text { Channel }\end{array}$ & Quaternary & Alluvium & $\begin{array}{l}\text { Intermittent Floodplain } \\
\text { Channel }\end{array}$ & cobbles, gravel & Q,a,ifc,c-g & $\begin{array}{l}\text { IFpC's are usually located near the } \\
\text { inside of meander bends/opposite of } \\
\text { constricting railroad structures. IFpC's } \\
\text { contained water in channel during field } \\
\text { data collection. }\end{array}$ \\
\hline Pnnr & $\begin{array}{l}\text { New River } \\
\text { Formation/ } \\
\text { sandstone } \\
\text { outcrop }\end{array}$ & Pennsylvanian & na & Bedrock Outcrop & sandstone & P,bdrk,ss & $\begin{array}{l}\text { Stream-side bedrock outcrop of the } \\
\text { New River Formation in the Pottsville } \\
\text { Group. }\end{array}$ \\
\hline $\mathrm{Mh}$ & $\begin{array}{l}\text { Hinton Formation/ } \\
\text { sandstone and/or } \\
\text { shale outcrop }\end{array}$ & Mississippian & na & Bedrock Outcrop & $\begin{array}{c}\text { sandstone and/or } \\
\text { red and green } \\
\text { shale }\end{array}$ & M,bdrk,sh & $\begin{array}{l}\text { Stream-side bedrock outcrop of the } \\
\text { Hinton Formation in the Mauch Chunk } \\
\text { Group. }\end{array}$ \\
\hline
\end{tabular}

Table 3. An application of the 4-fold surficial geology mapping method (Kite, 1996) categorizing the inventoried morphologic features of Shavers Fork, West Virginia. 


\section{Physiography, Climate, and Soils of Shavers Fork}

The upper Shavers Fork near the lower end of the study area is a fifthorder tributary to the Cheat River (Figure 2). The field area is located in the eastern portion of the Appalachian Plateaus physiographic province (Flegel, 1992). U.S. Route 219, approximately $9.7 \mathrm{~km}$ north of Durbin, West Virginia, provides access to the downstream end of the Shavers Fork field area. Bedrock underlying the ridges surrounding the stream valley are slightly dipping, resulting in a north-northeast flowing, low-gradient trellis drainage pattern for the mainstem of Shavers Fork. Conversely, high-gradient tributaries exhibit a dendritic drainage pattern due to the nearly horizontal Pennsylvanian resistant cap-rock at high elevations and the easily eroded Mississippian rock situated stratigraphically lower.

Winters are cold and snowy, but intermittent thaws occur. The average winter temperature is $-5.0^{\circ} \mathrm{C}\left(23^{\circ} \mathrm{F}\right)$, and the average summer temperature is $16.7^{\circ} \mathrm{C}\left(62^{\circ} \mathrm{F}\right)$ (Flegel, 1992). Total annual precipitation at Snowshoe is $132 \mathrm{~cm}$ (52 in) and the average snowfall is $3.96 \mathrm{~m}$ (156 in) (Flegel, 1992). Prevailing winds are from the northwest, and rainfall is generally heavier on west-facing slopes (Flegel, 1992).

The Delkalb-Buchanan soil association dominates mountainous uplands, foot slopes, and mainstem channel. Upland and footslope soils are sloping, well drained, acidic, and derived from the weathering of upslope colluvial material that predominantly consists of sandstone, with limited amounts of shale, 
siltstone, and limestone (Flegel, 1992). Shavers Fork is bounded by a deep, poorly drained, strongly acidic, silt loam floodplain primarily derived from alluvial processes (Pyle and others, 1983).

\section{Land Use History and I mpacts to Shavers Fork}

Extractive timber and coal operations were the major land uses in this area from the 1880's to the 1920's (Price and Reger, 1929; Clarkson, 1964;

Deike, 2000). The timber industry preceded the coal industry (Clarkson, 1964). The watershed contained deciduous, coniferous, and mixed coniferous and deciduous forest. The area was noted for its fine stands of red spruce (Picea rubens). Early loggers cleared riparian vegetation and removed large in-stream boulders to facilitate floating logs to downstream mills (Clarkson, 1964; Deike, 2000). Later, railroad construction further impacted Shavers Fork by reducing the floodplain area and riparian habitat.

The upper 607 hectare (1500 acres) Mower Lumber tract was sold to Snowshoe Ski Resort in 1973 (Figure 4) and the remaining Mower Lumber Company tract was sold to the United States Forest Service in 1988. The last coal train ran in the upper Shavers Fork in 1993 (Deike, 2000). The only remaining virgin spruce untouched by timber operations within the field area is located at Gaudineer Knob. 


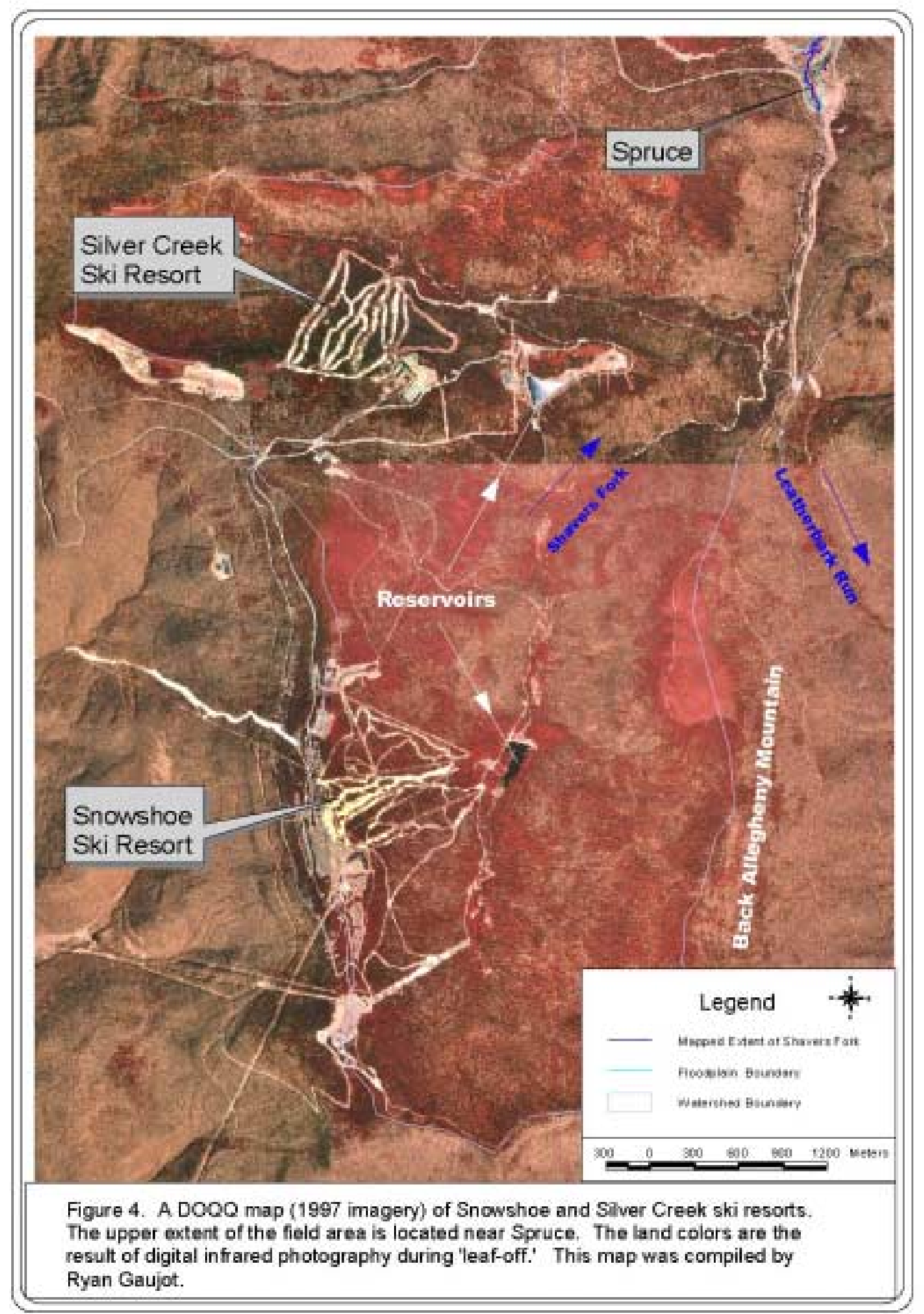


Considering the area's extractive land-use history, the watershed is relatively intact, although the fishery has been significantly degraded (Petty, 1999). Large temperature fluctuations and scoured fish habitat occur coupled with the loss of in-stream and riparian heterogeneity (Petty, 1999). Today, recreation is the major land use of the upper Shavers Fork, where outdoor enthusiasts enjoy skiing, fishing, hunting, boating, biking, scenic train-rides, pleasure walks, and various aesthetic details of the area.

\section{Stratigraphy of Shavers Fork}

The North Potomac syncline dominates the structural geology underlying Shavers Fork (Figure 5). Mississippian and Pennsylvanian age sedimentary strata constitute the bedrock from Snowshoe to the end of the field area at Lambert Run (Table 4).

The bedrock stratigraphy of the entire basin from the headwaters to the downstream limit of study near Lambert Run is internally similar. Within the study area, the channel of Shavers Fork is confined to the shale-rich Hinton Formation. Red, green, and medium-gray shales and sandstone comprise most of the Hinton members, with a few thin limestone beds. The up-slope sandstone units of the Kanawha and New River formations are within the Pottsville Group. Sandstones in the study area are very well indurated and resistant to erosion. The higher stratigraphic units influence stream ecology by providing boulders delivered to the stream by slope processes. The absence of 
calcareous strata in the watershed renders the mainstem naturally acidic, with little or no buffering capacity (Sherlock, 1997). The small percentage of

limestones and concrete found in the streambed are anthropogenically introduced.

\begin{tabular}{|c|c|c|c|c|}
\hline & Group & Formation & Dominant Rock Type & Associated Surficial Geology \\
\hline & Pottsville & Kanawha & $\begin{array}{l}\text { Sandstone }(\sim 50 \%) \text {, } \\
\text { shale, siltstone, coal }\end{array}$ & $\begin{array}{l}\text { Less resistant than New River, } \\
\text { Kanawha bedrock caps high } \\
\text { mountains in western and northern } \\
\text { limits of study area, coal mines }\end{array}$ \\
\hline 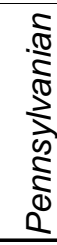 & Pottsville & New River & $\begin{array}{c}\text { Sandstone }(\sim 70 \%), \\
\text { conglomerate, shale, } \\
\text { siltstone, coal }\end{array}$ & $\begin{array}{l}\text { Flat-topped summits bordered by } \\
\text { steep slopes with large boulders that } \\
\text { may be transported to channel of } \\
\text { Shavers Fork and it's tributaries. }\end{array}$ \\
\hline 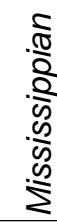 & Mauch Chunk & Bluestone & $\begin{array}{l}\text { Shale, siltstone, } \\
\text { sandstone }\end{array}$ & $\begin{array}{l}\text { Generally steep slopes, locally } \\
\text { mantled by course bouldery debris } \\
\text { from overlying Pottsville Sandstone. } \\
\text { (Possible source of debris flows) }\end{array}$ \\
\hline & Mauch Chunk & Princeton & Sandstone & $\begin{array}{l}\text { Relatively thin sandstone unit, } \\
\text { producing large boulders, and } \\
\text { waterfalls in tributaries }\end{array}$ \\
\hline & Mauch Chunk & Hinton & $\begin{array}{l}\text { Shale, siltstone, } \\
\text { sandstone }\end{array}$ & $\begin{array}{l}\text { Underlies valley floor throughout mos } \\
\text { of the study area. Shale and siltston€ } \\
\text { intervals yield cobbles and finer } \\
\text { materials, wide floodplains. } \\
\text { Sandstone lenses yield boulders, } \\
\text { waterfalls, and narrow floodplains. }\end{array}$ \\
\hline
\end{tabular}

Table 4. Bedrock stratigraphy of the upper Shavers Fork field area. The Mississippian section measures Approximately 250 - 400 feet. 


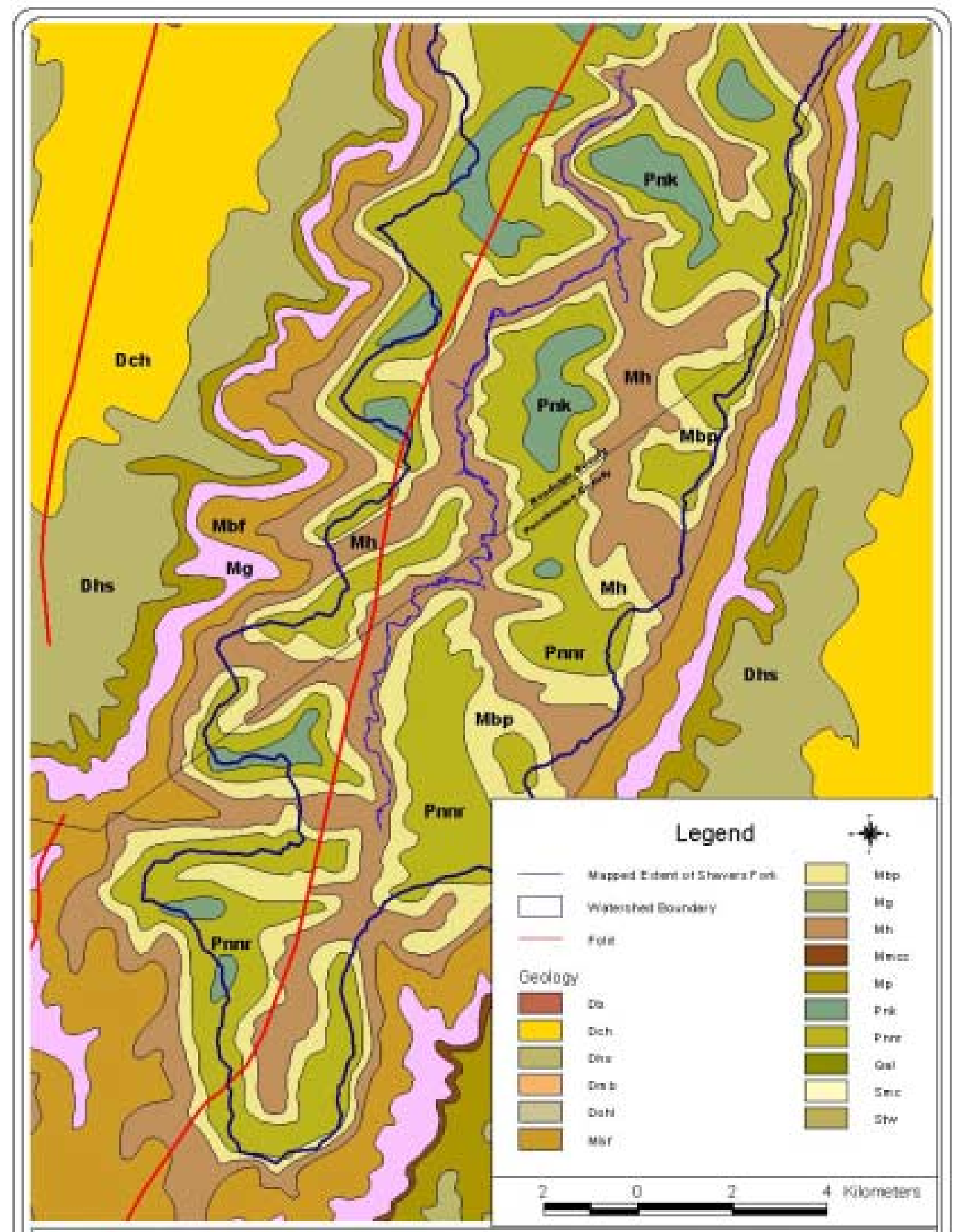

Figure 5. A geologic map of the Shavers Fork field area with abbriviated lithologic map units and the axis of major folds in red. The blue line indicates the mapped extent of Shavers Fork. This map was compiled by Ryan Gaujot after the state geologic map. 


\section{The Shavers Fork Fishery}

Modern assessments of inland aquatic ecosystems have given rise to several remediation concepts that are applicable to the upper Shavers Fork aquatic environment (Figure 6). Considering the historic extractive land uses, the upper Shavers Fork does posses integrity, which indicates the system is intact and restorable to it's morphological and biological potential. Specific environmental stresses that determine the suitability of a particular fish are fluvial hydraulics, stream morphology, channel gradient, stream-bank characteristics, bedrock and alluvial lithology, and water temperature (Minshall, 1996).

Shavers Fork in-stream complexity is highly variable, and topography, geology, and precipitation control the basin characteristics. Fluvial processes within the basin modify bedrock surfaces and develop different habitats. Smallscale habitats are embedded within larger habitat mosaics at increasing hierarchical levels (Petty, 1999). In-stream features that constitute fish habitat are resolved at several different scales, and different levels of morphological resolution are obtained by subdividing the stream into segments, reaches, channel units, microhabitats, etc. Fish adapt to chemistry, discharges, channel morphology, and substrate composition. These varying geomorphologic components subdivide brook trout populations occupying specific habitat types. The quality of fish habitat is a direct function of the homogeneity or 


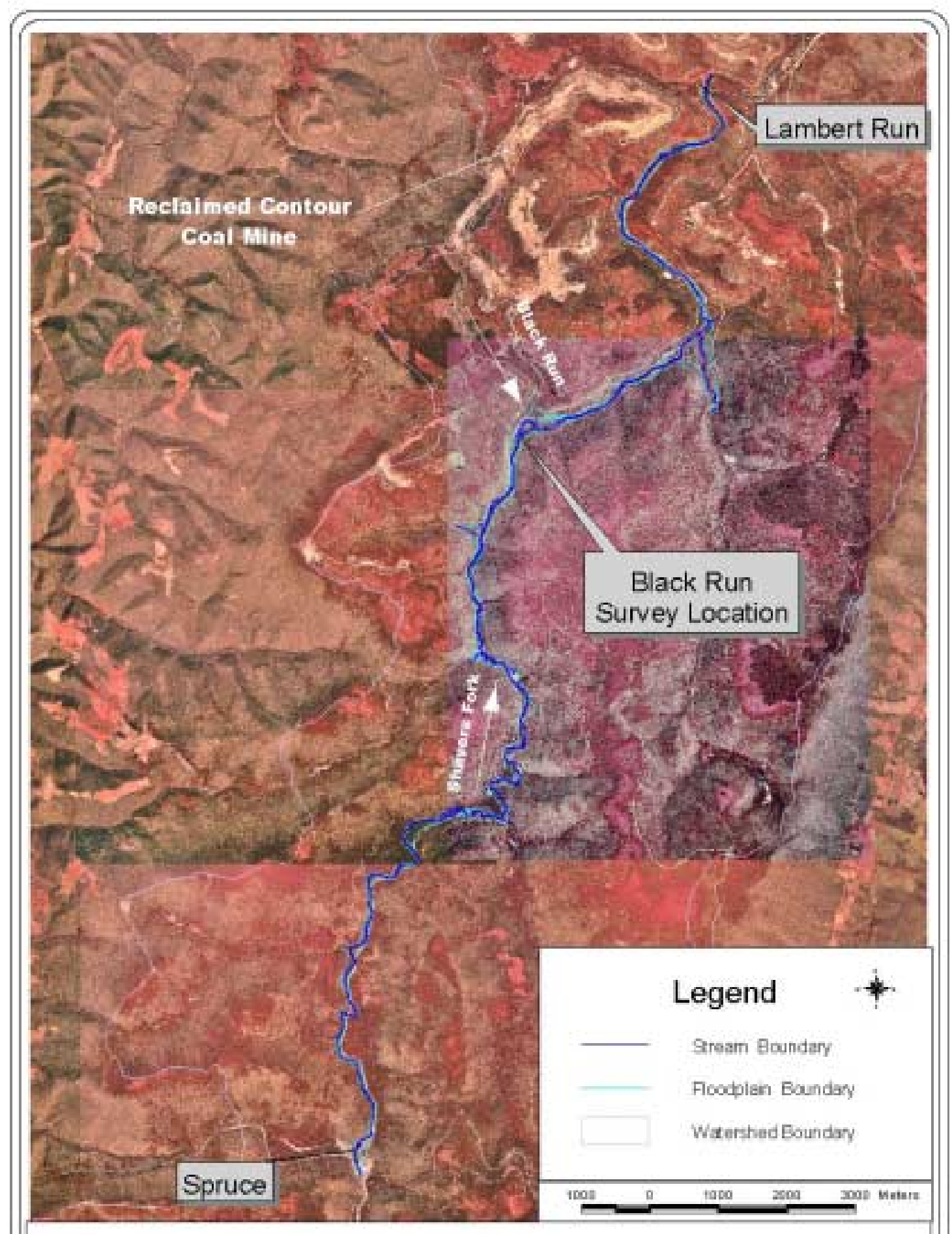

Figure 6. A DOQQ (1997 imagery) of the mapped extent of Shavers Fork. This map was compiled by Ryan Gaujot. 
heterogeneity of flow characteristics and in-stream features (Rabini, 1993).

Inferences on the biological structure and functional integrity of Shavers Fork are made by analyzing the building blocks of aquatic habitats within specific channel units.

\section{Channel-Units}

Stream water is the medium of support and movement for fish and other aquatic organisms. Bank morphology, channel gradient, channel form, stream bottom composition, and the volume of water in the channel dictate stream flow characteristics. Channel-units are subdivisions of a stream that represent flow characteristics with unique hydraulic properties. The morphology that defines channel units within a stream reach controls the biological structure of the aquatic habitat and the way it functions (Minshall, 1996). Channel-unit descriptions address local stream flow, gradient, area, depth, and channel obstructions and constrictions, including large woody debris (Hawkins and others, 1993). Petty (1999) defined channel units as discrete areas that can be classified consistently using criteria known to affect aquatic life, ultimately indicating factors that limit populations within a stream reach. Maxwell and others (1995) defined channel units as areas of consistent depth and flow bounded by sharp changes in gradient.

Channel-unit characterizations constituted the most detailed level of classification for morphological research in Shavers Fork. The channel-unit data 
included contiguously mapped hydrologic boundaries that are unique in terms of homogeneity or heterogeneity (Appendix I \& II). The contiguous arrangement of channel-units is a fundamental component of the quality of fish habitat in the stream. Thus, inferences on the biological structure and functional integrity of Shavers Fork can be made through delineation of the geomorphologic building blocks of the aquatic habitats.

Channel-unit classification varies with flow conditions, as does brook trout habitat variability. Channel units were determined under base-flow conditions to minimize problems with variations in discharge. Shavers Fork channel units were classified according to the 'real-time' flow characteristics within a stream reach. Channel-unit complexes were classified according to the sequence of flow characteristics in the downstream direction. Most channel units, on the map and in Appendix I \& II, are labeled with abbreviations (given in italics in the following text), with the exception of pools. A description of geologic complexity, relative flow velocity, substrate and water surface profile, and overall quality of fish habitat was given to each unit.

\section{Riffles}

Lgr, Igr, Hgr signifies low gradient riffle, intermediate gradient riffle, and high gradient riffle, respectively. Riffles are shallow channel units with critical flow where water flows swiftly over completely or partially submerged obstructions or alluvium, producing surface agitation but no standing waves 
(Maxwell and others, 1995). The longitudinal profile of the substrate is usually uniform or convex. A well-defined thalweg occurs locally and marginal slackwater occurs near the stream banks. All riffles are similar in channel form and substrate. These homogeneous channel units provide poor to good quality fish habitat and may or may not have anthropogenic influences.

Pools

Pools are deep channel units where the flow velocity is extremely low to stagnant. Most pools occur downstream from constrained regions of higher velocity and provide areas of temporary deposition at low flows. The profile of the substrate is concave. Pools are created during high flow conditions when water passes through or over obstructions and scours out a concave depression in the substrate downstream of the obstruction (Maxwell and others, 1995). Debris pools occur when a downstream debris dam causes low-velocity pooling upstream. Pools should not be confused with glides as the flow velocity and substrate profile should distinguish them. Cyclic eddy phenomena, in the form of upwellings, occur in this channel unit and provide infrequent surface-water agitation (Morisawa, 1968). Anthropogenic features, such as abandoned bridge foundations and existing tressels, influence the occurrence of many pools. The boundary between pools and the adjacent upstream channel unit is excellent congregation habitat for fish. 


\section{Glides}

Gld signifies glide. Glides have low flow velocity, uniform depth, and no surface agitation. The longitudinal profile of the substrate is roughly parallel to the slope of the water surface and there is no well-defined thalweg. Glides are homogeneous channel units with poor quality fish habitat.

\section{Riffle-Run Complexes}

$\operatorname{LgrRC} C_{A}, \operatorname{IgrRC} C_{A}, H g r R C_{A}$ signifies a natural low-gradient riffle-run complex $(A)$, intermediate-gradient riffle-run complex $(A)$, high-gradient riffle-run complex (A), respectively. Large cobbles and small boulders scattered throughout the channel provide many irregular holes that inhibit the development of a clear, defined thalweg. In-stream and riparian cover is abundant. The complex starts as flow is constrained and accelerated through habitat features such as alluvial cobbles or small boulders. Throughout the beginning of the complex, the water exhibits streaming flow (sub critical flow) under base-flow conditions, but shooting flow (critical flow) occurs with more discharge. The water's surface is aerated and roughly parallel to the overall gradient of a stream reach. As water accelerates downstream, it deflects off and around mid-channel boulders of all sizes, causing separations of flow and small mid-channel eddies. The boulders are derived from upslope colluvial processes, tributary confluences, or eroded bank-side bedrock. These three types of riffle-run complexes are heterogeneous and yield good to excellent quality fish habitat. 
$\operatorname{LgrRC}_{B}, \operatorname{lgrRC} C_{B}, H g r R C_{B}$ signifies a human impacted low-gradient rifflerun complex (B), intermediate-gradient riffle-run complex (B), high-gradient riffle-run complex (B), respectively. The anthropogenic channel units have constraining features such as railroad ties or concrete blocks. These complexes have high heterogeneity and provides generally good to excellent fish habitat, although riparian cover is usually sparse.

\section{Riffle-Glide Complexes}

LgrGldC, IgrGldC signifies low-gradient riffle-glide complex and intermediate-gradient riffle-glide complex. These channel units typically are comprised of approximately 50 percent riffle and 50 percent glide characteristics. As water moves through the channel, it deflects around mid-channel cobbles and boulders, causing separations of flow and small mid-channel eddies. These complexes are mostly heterogeneous and provide good quality fish habitat where vegetation is well developed.

\section{Bluff-Pool Complexes}

$B P C_{A}$ signifies a natural bluff-pool complex (A). Bluff-pool complexes usually have good in-stream and riparian cover, including boulders, woody debris, and root wads. The complex starts where flow is constrained and accelerated through habitat features, such as alluvial cobbles or small boulders. Here, the water exhibits streaming flow, but shooting flow can occur at higher 
discharge. The water surface is aerated and roughly parallel to the overall gradient of a stream reach. As the water accelerates, it deflects off natural bedrock or boulder bluffs on the bank causing change in flow direction. Locally, these bluffs are formed by bedrock walls up to $5 \mathrm{~m}$ in height. The deflection of the flow direction at high flow commonly causes a scour pool just downstream from the bluff. Scattered mid-channel boulders are derived from local bluffs and cause separations of flow and small mid-channel eddies throughout the bluffpool (A) complex. This complex has high heterogeneity and provides generally good to excellent fish habitat.

$B P C_{B}$ signifies a human-impacted bluff-pool complex (B). This unit has constraining and scour pool features similar to bluff-pool complex (A), but the bluff component is railroad related, such as bankside ballast or concrete blocks. Tressel complexes also fall into the bluff-pool complex (B) category. This complex has high heterogeneity and provides generally good to excellent fish habitat although riparian cover is usually sparse. 


\section{Results}

The results of this research are derived from geomorphic mapping and analysis of the field data listed in Appendix I and II. The BVET calibration ratio (Q) applied to estimated variables of bankfull width and maximum depth was calculated using the equation below:

$$
Q=\Sigma m / \Sigma x
$$

Where $Q$ is an estimator of the true ratio of the area of all the units, $m$ is the true measured unit, and $x$ is the visual estimate (Hankin and Reeves, 1988). The calibration ratio $(Q)=0.96$ was generated from $m$ and $x$ data listed in Table 5 . The calibration ratio represents an estimate of the true ratio of channel unit areas to visually estimated areas. 


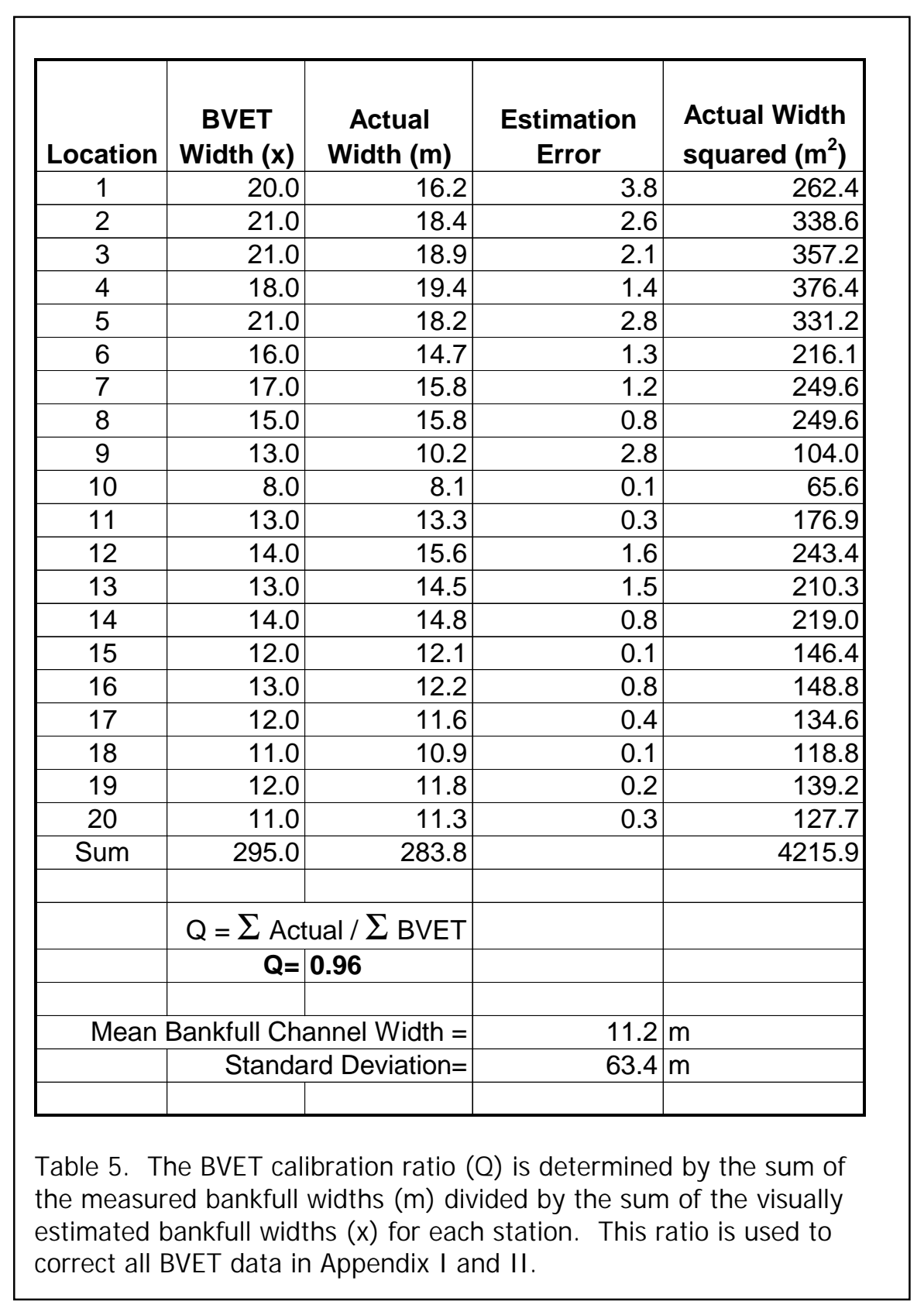




\section{Watershed Characteristics}

The basin area, encompassing the area from Thorny Flat to Cheat Bridge (Figure 3), is $155.40 \mathrm{~km}^{2}$, as given for the USGS gauge station on Shavers Fork at Cheat Bridge. Figure 7 shows a longitudinal profile from Thorny Flat to Cheat Bridge. The basin length is $16.60 \mathrm{~km}$ straight-line measured from Thorny Flat peak to Cheat Bridge (Figure 3). The basin relief from the highest point at Bald Knob to Cheat Bridge is $384 \mathrm{~m}$ and was calculated using the USGS topographic quadrangles. The mapped stream length from Spruce to Lambert Run (Figure 3) is $24.6 \mathrm{~km}$. Within the mapped field area, Shavers Fork drops $84.15 \mathrm{~m}$ from Spruce to Lambert Run as determined from USGS topographic maps.

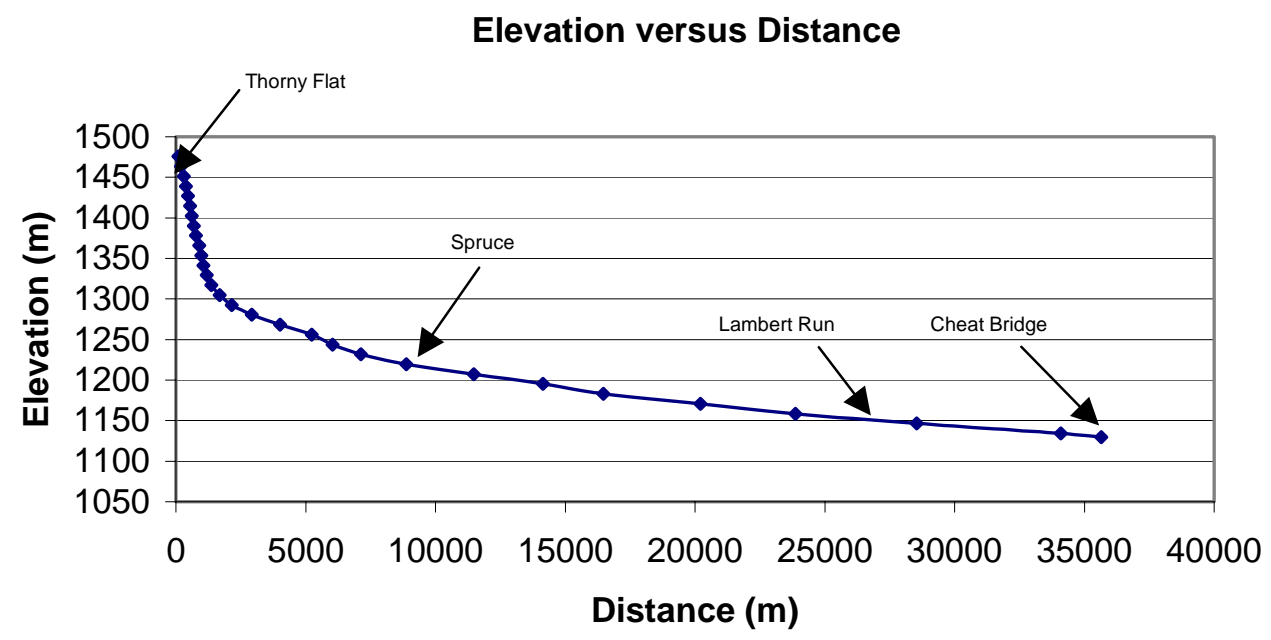

Figure 7. A longitudinal profile of Shavers Fork from Thorny Flat to Cheat Bridge. This map was generated from data published on 1:24,000 USGS topographic quadrangles. 
Channel Unit Results

The field area contained 393 channel units. Data for the 393 contiguous channel units are listed in Appendix I. Linear regressions show the downstream trends in bankfull width (Figures 8-14), channel unit length (Figures 15-21), channel unit area (Figures 22-28), and maximum depth (Figures 29-35). The mean and standard deviation for each channel-unit type's bankfull width, length, area, and maximum depth area are shown in table 6.

\begin{tabular}{|c|c|c|c|c|c|c|c|c|}
\hline & $\begin{array}{l}\text { Mean } \\
\text { Berkful } \\
\text { Whdh } \\
\text { (m) }\end{array}$ & $\begin{array}{l}\text { Standard } \\
\text { Deviation } \\
\text { of Mean } \\
\text { Barkfull } \\
\text { Wolh }(m)\end{array}$ & $\begin{array}{l}\text { Mean } \\
\text { Ohannd } \\
\text { Unit } \\
\text { Length } \\
\text { (m) }\end{array}$ & $\begin{array}{l}\text { Standard } \\
\text { Deviation } \\
\text { of Meen } \\
\text { Oreme } \\
\text { Unit Length } \\
\text { (m) }\end{array}$ & 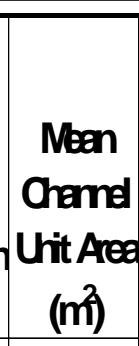 & $\begin{array}{c}\text { Sendard } \\
\text { Devidion } \\
\text { of Mean } \\
\text { Oremi } \\
\text { Uit Area } \\
\text { (mî) }\end{array}$ & \begin{tabular}{|c|} 
\\
Meen \\
Meximum \\
Depth \\
Value(m)
\end{tabular} & $\begin{array}{c}\text { Standad } \\
\text { Devizion } \\
\text { of Mern } \\
\text { Meximm } \\
\text { Depth } \\
\text { Value(m) }\end{array}$ \\
\hline Pffles & 162 & 4.1 & 45.5 & 29.7 & 7532 & 601.4 & 0.5 & 0.7 \\
\hline Pods & 11.3 & 14.1 & 254 & 347 & 4667 & 724.9 & 0.8 & 0.9 \\
\hline Gides & 17.0 & 34 & 638 & 51.1 & 11780 & 1151.9 & 0.6 & 0.7 \\
\hline Rfflenuncomplexes & 150 & 4.4 & 727 & 462 & 11633 & 969.9 & 0.8 & 0.2 \\
\hline FiffleglideComplexes & 14.8 & 32 & 930 & 562 & 17853 & 134.0 & 0.6 & 0.2 \\
\hline Buff-pod Complexes & 14.3 & 31 & 733 & 40.4 & 10980 & $6 / 28$ & 0.9 & 0.2 \\
\hline
\end{tabular}

Table 6. Channel-unit means and standard deviations for bankfull width, length, area, and maximum depth. 


\section{Bankfull Width}

Channel-unit bankfull width generally increases in the downstream direction from Spruce to Lambert Run (Figure 8). The average bankfull channelunit width is $16 \mathrm{~m}$, with the most narrow mean width located in segment 7 and the widest mean width located in segment 11. Channel-unit bankfull width data for each channel unit type are illustrated on Figures 9 through 14. Riffle-glides constitute the widest channel units, with few less than $15 \mathrm{~m}$, although the widest unit is a simple riffle. Pools have the most variation in width with three narrow channel units less than $7 \mathrm{~m}$ wide. Bluff-pools are also considerably narrower than other channel units and complexes.

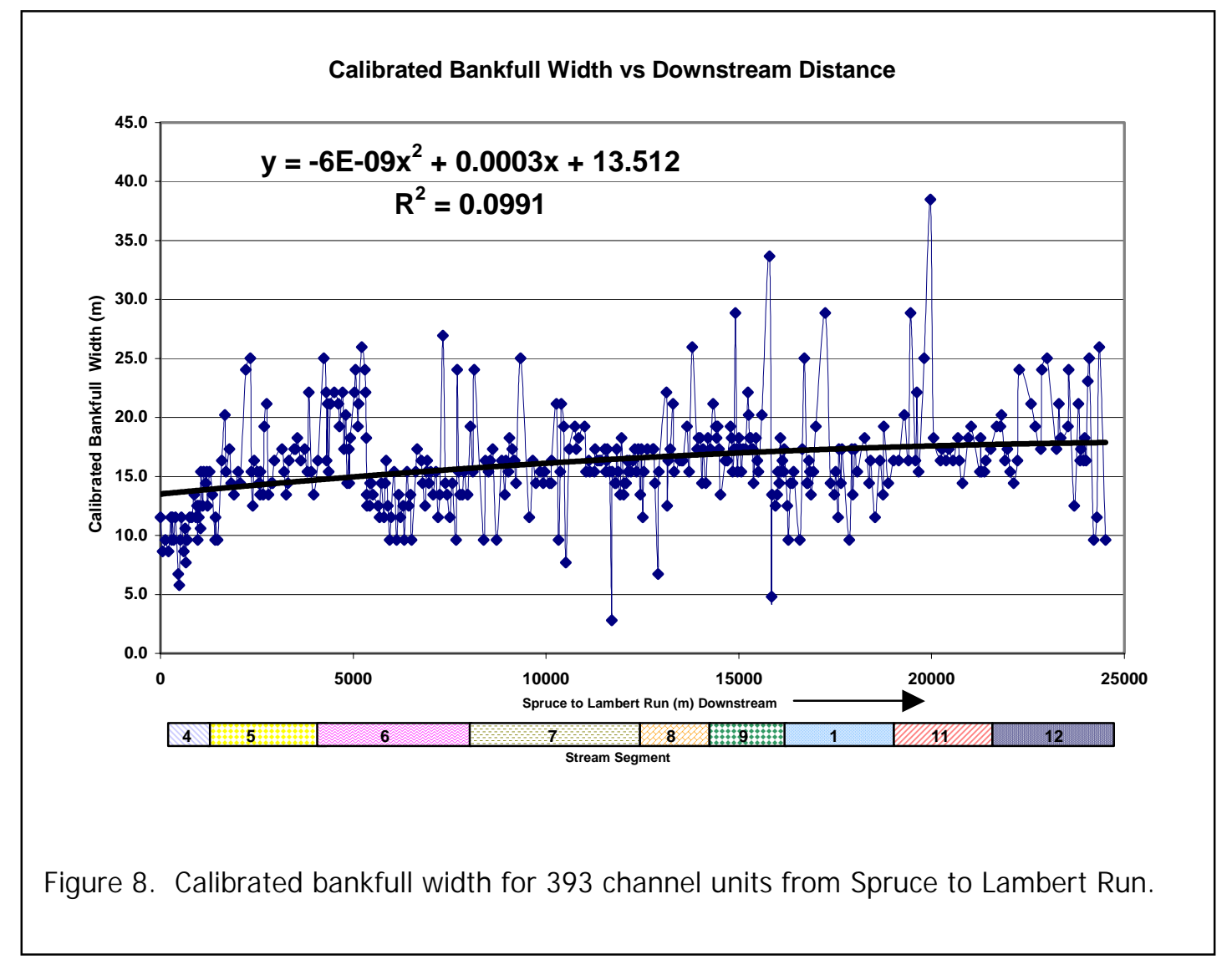




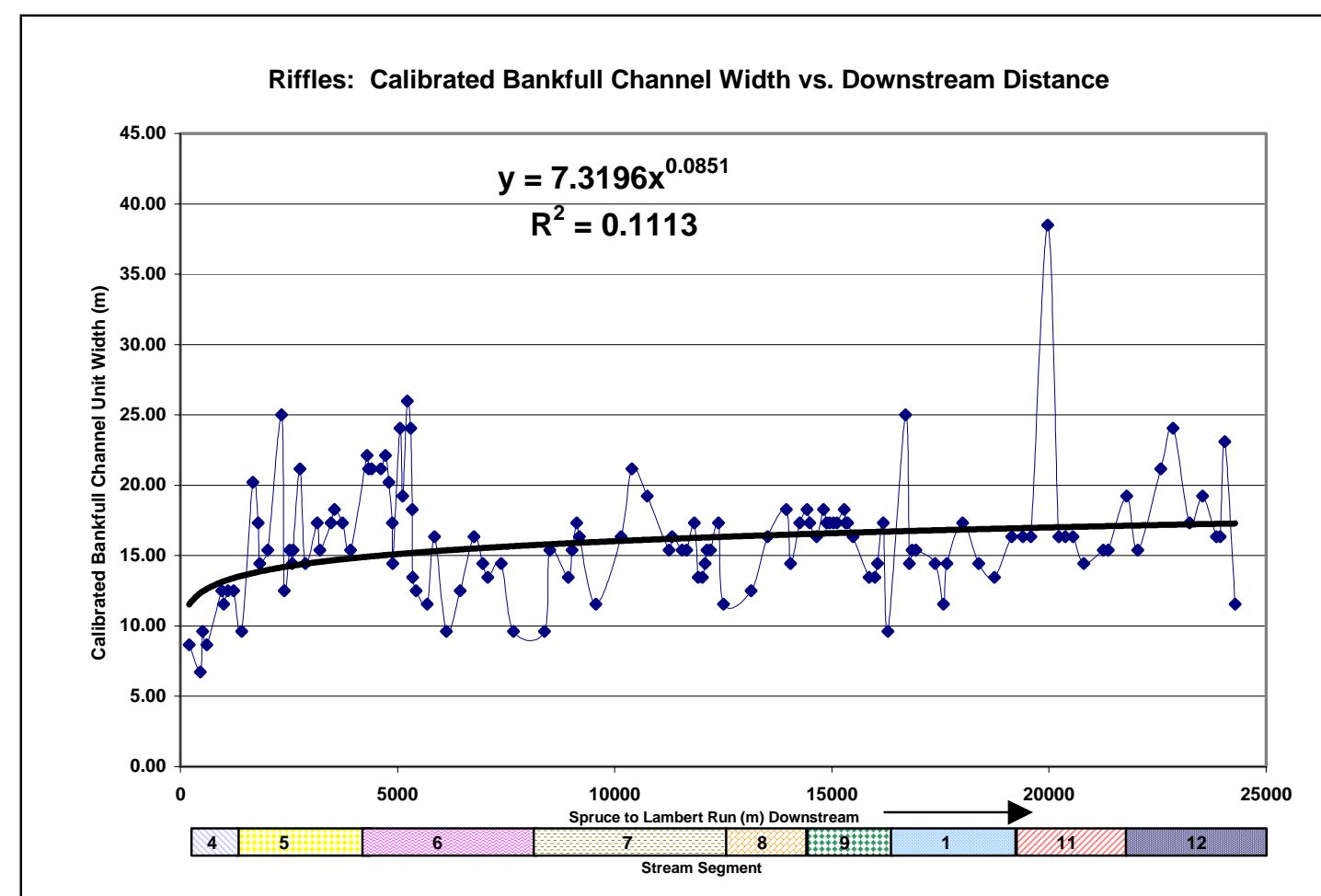

Figure 9. Calibrated bankfull width versus distance for riffles from Spruce to Lambert Run.

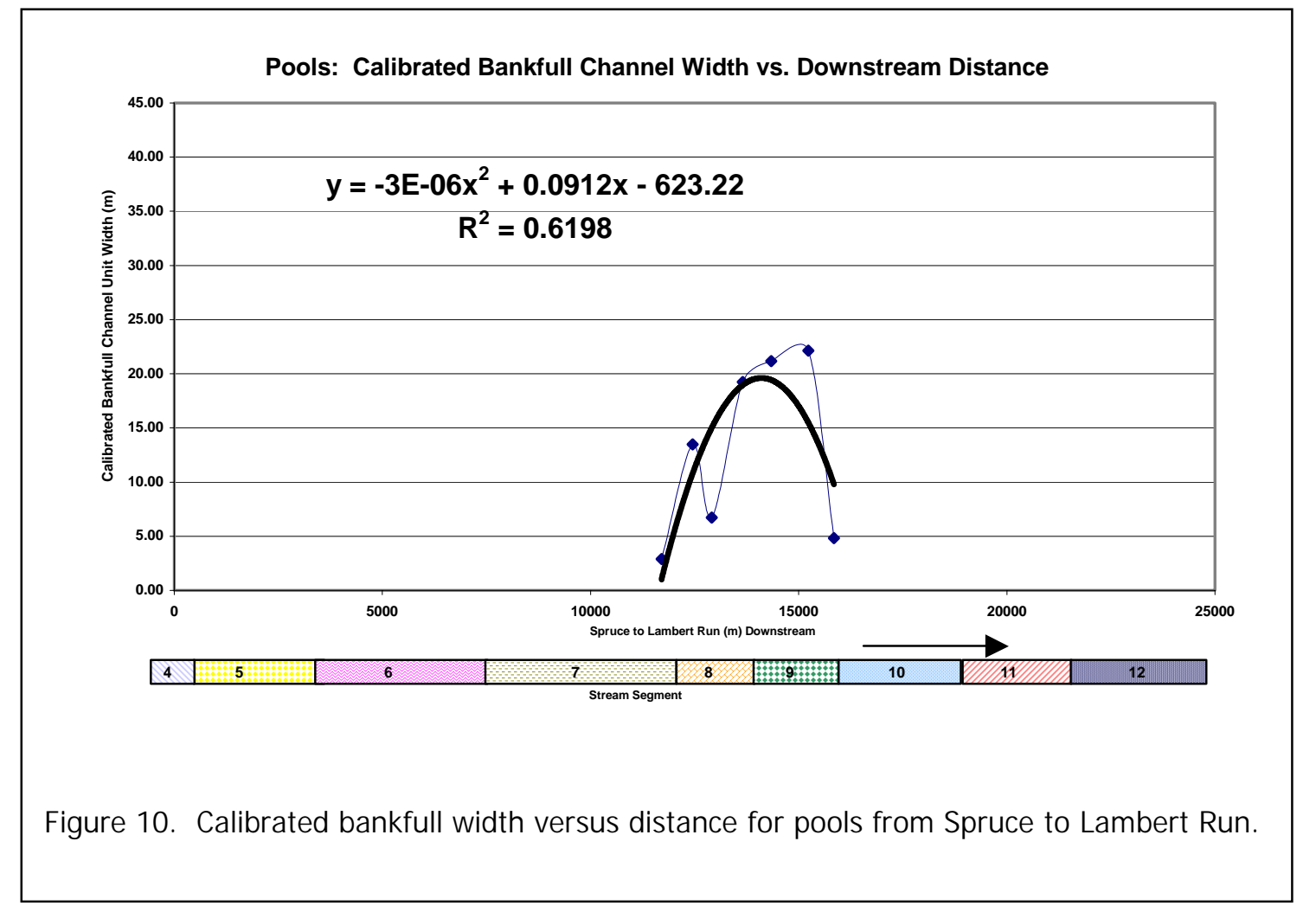



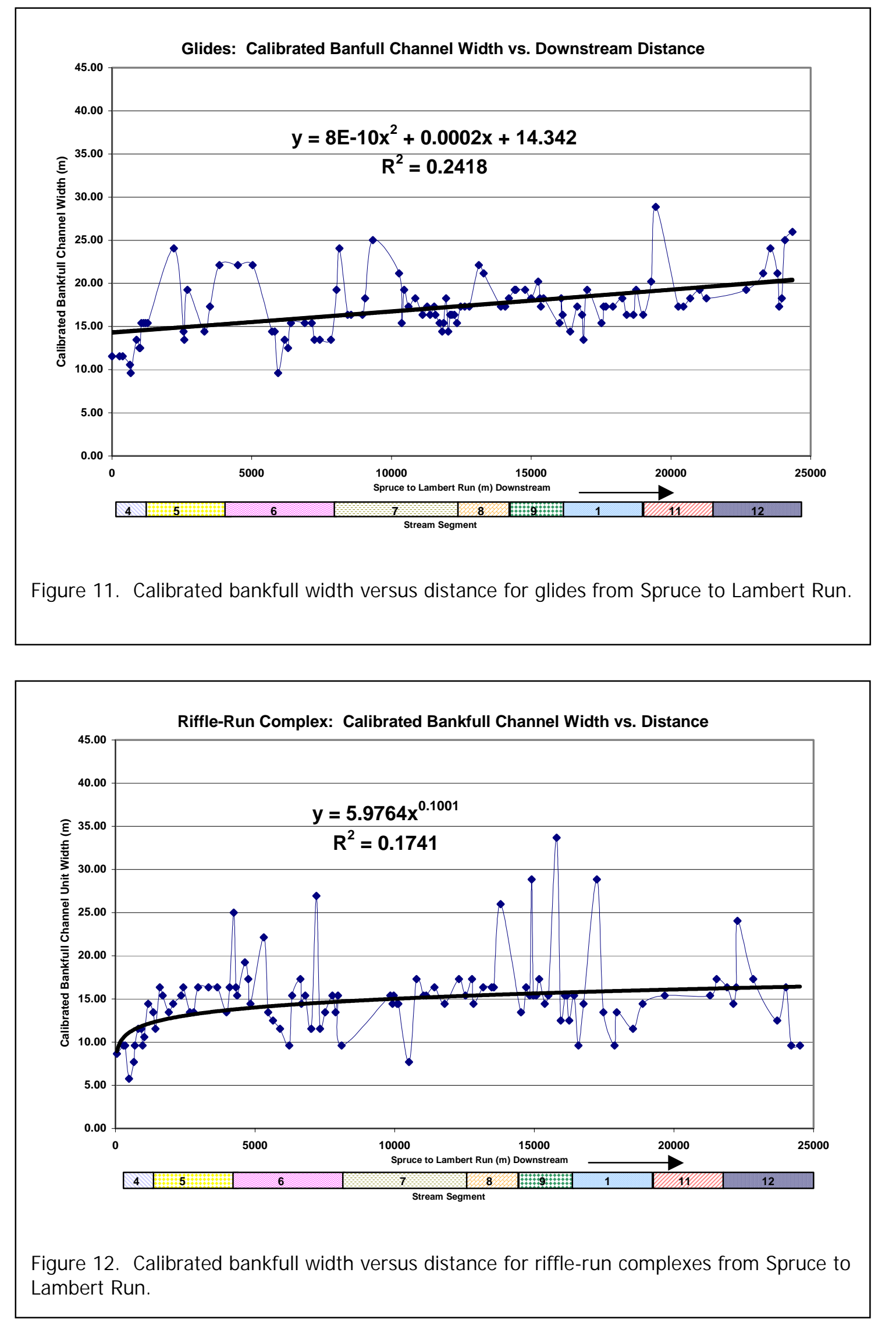


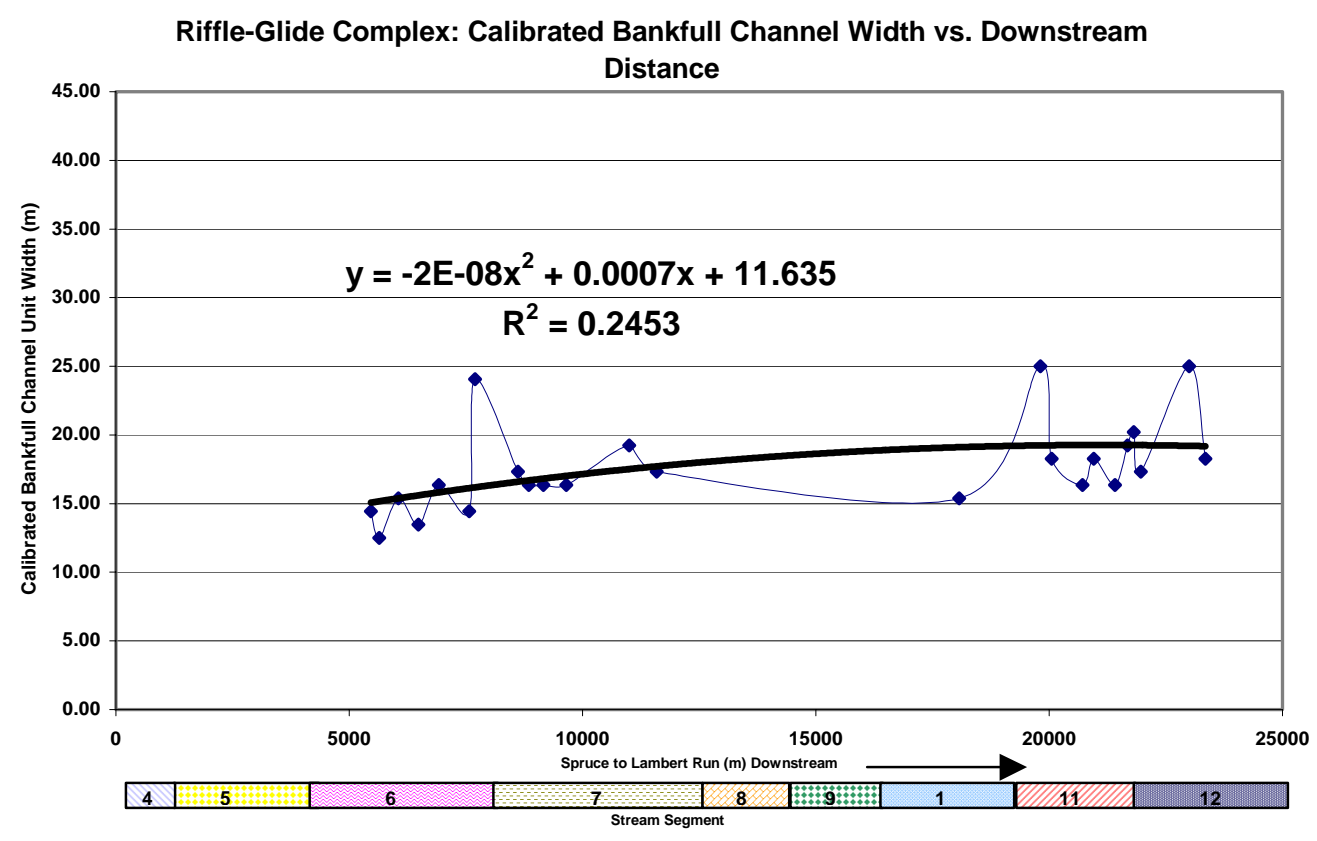

Figure 13. Calibrated bankfull width versus distance for riffle-glide complexes from Spruce to Lambert Run.

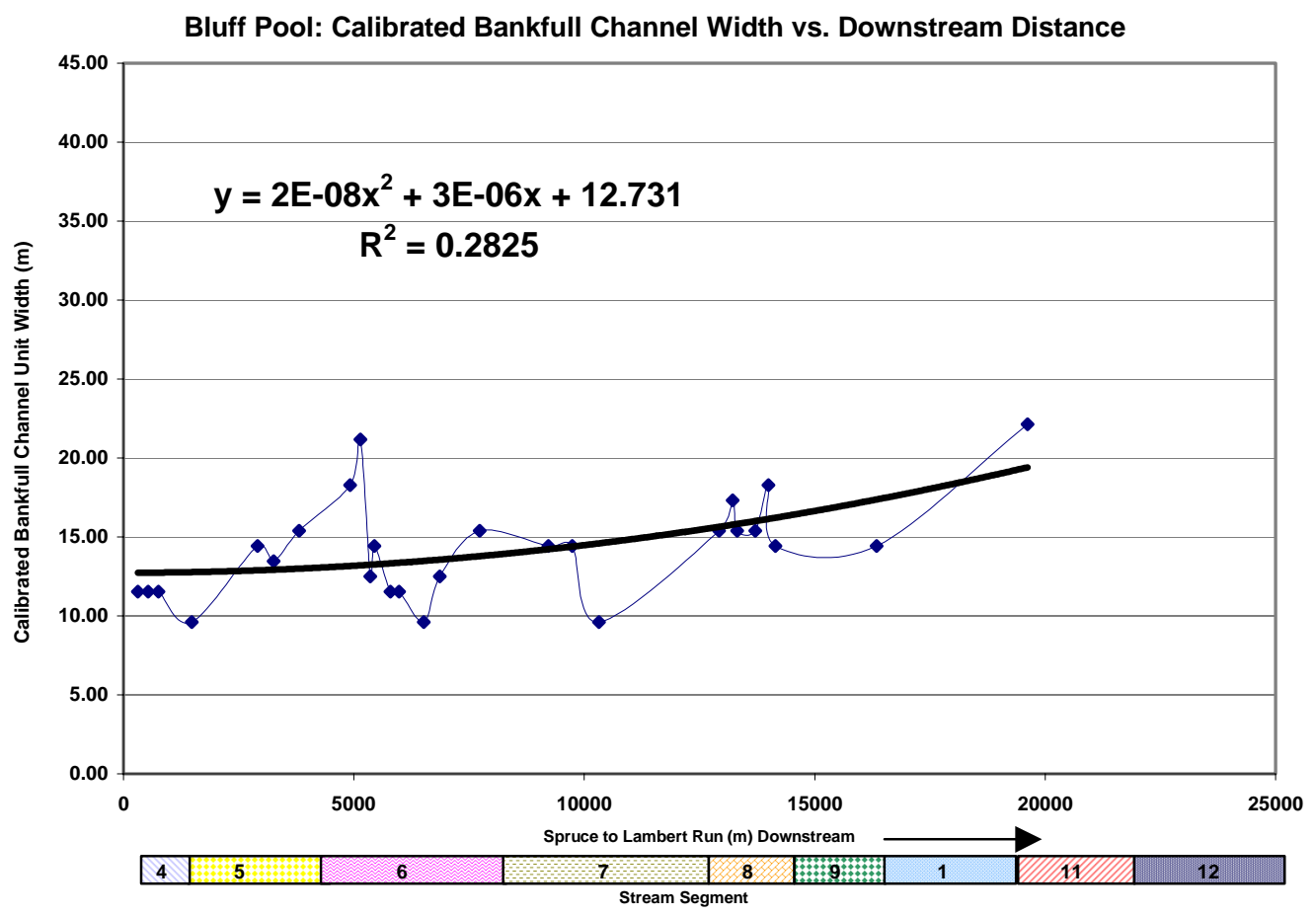

Figure 14. Calibrated bankfull width versus distance for bluff-pool complexes from Spruce to Lambert Run. 


\section{Channel Unit Length}

Channel-unit length averages $63 \mathrm{~m}$, but generally increases in the downstream (Figure 15). Channel-unit length variability is lower closer to Spruce (Figure 15) and indicates a higher concentration of shorter channel units near the headwaters. Channel-unit length trends for each channel-unit type are illustrated in Figures 16 through 21. Glides and riffle-glides composed the longest channel units, with the exception of one riffle-run over $300 \mathrm{~m}$ long. There are two unusually long pools in segments 8 and 9, one long riffle-run complex in segment 12 , and one long bluff-pool located near the boundary of segments 6 and 7 .

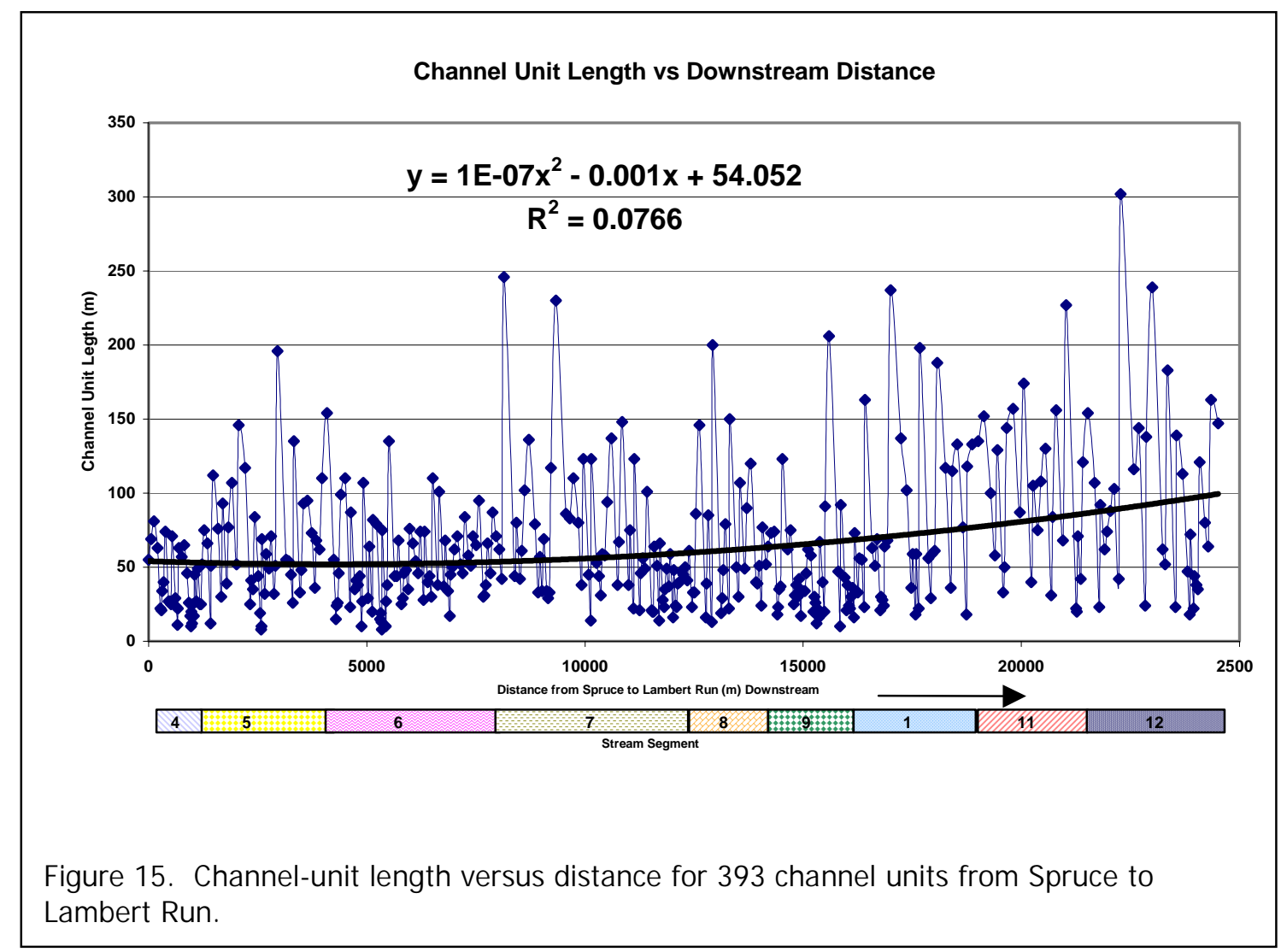



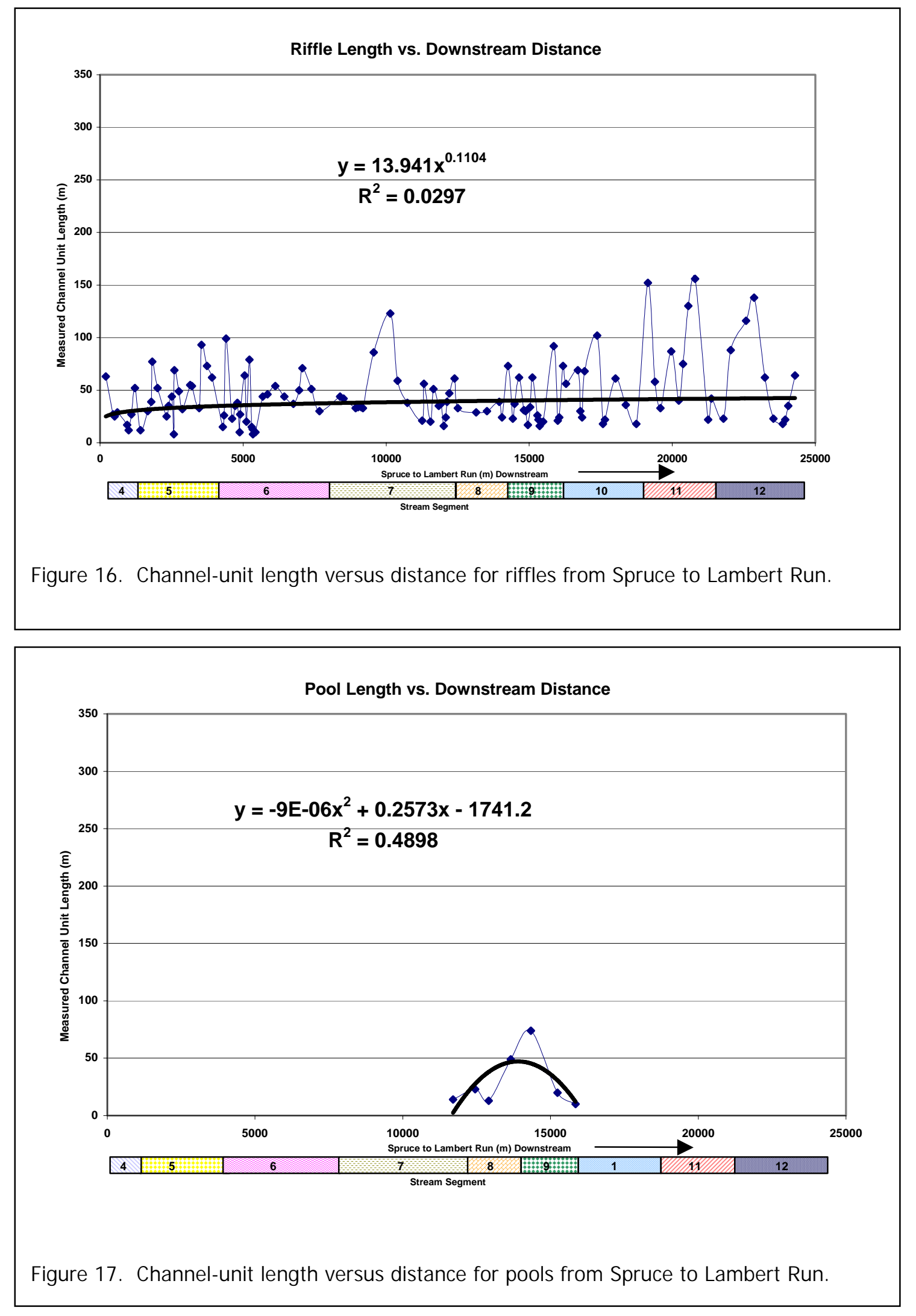

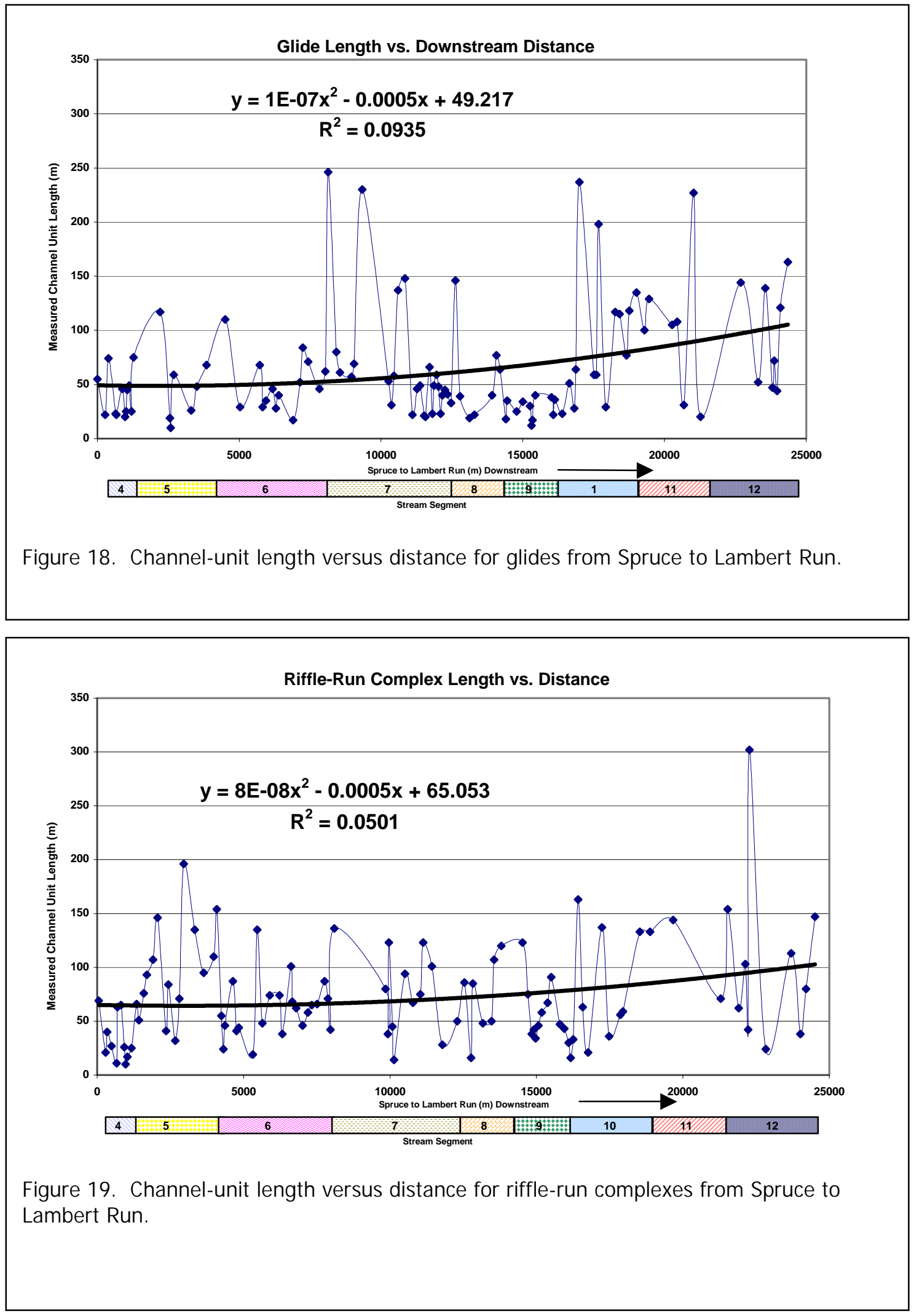


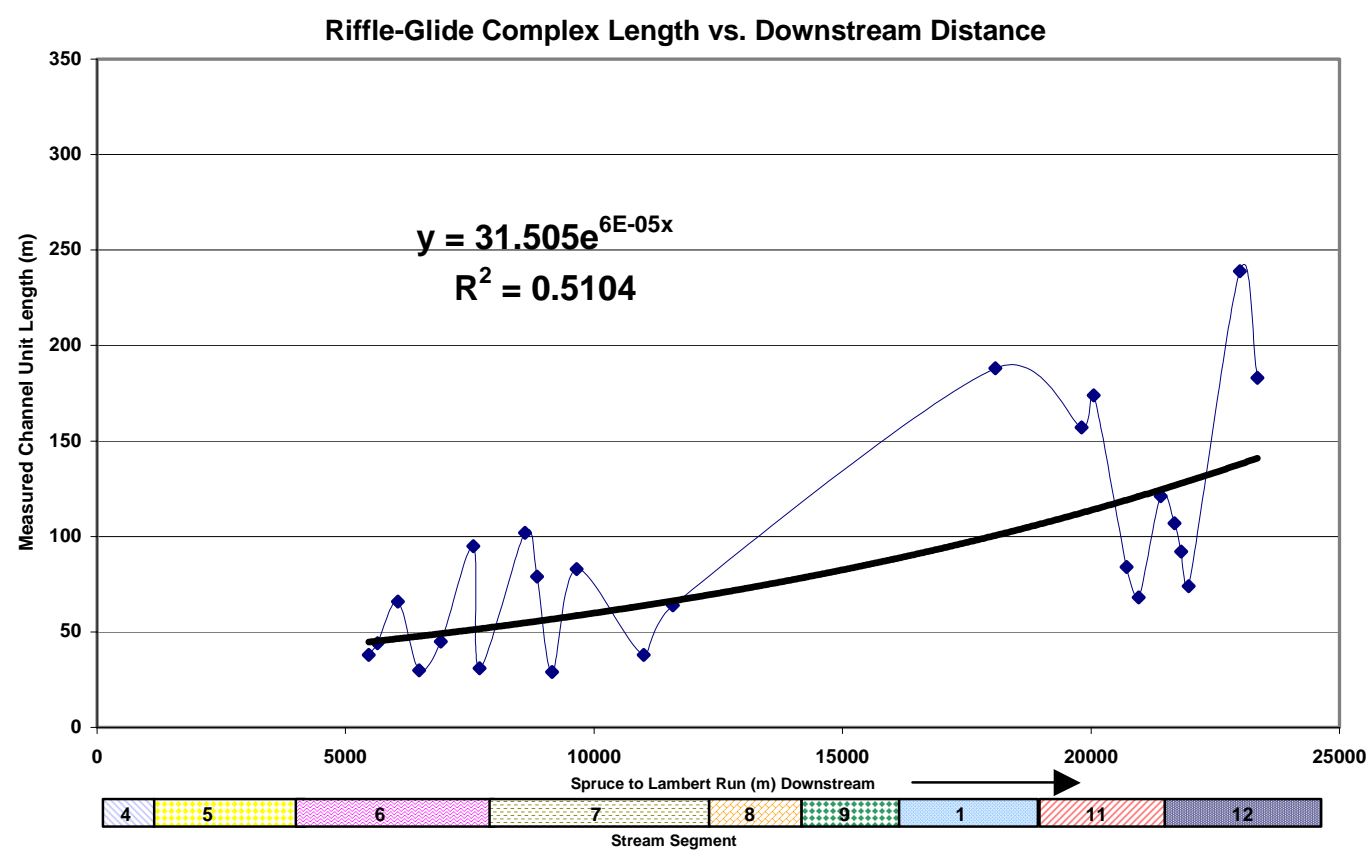

Figure 20. Channel-unit length versus distance for riffle-glide complexes from Spruce to Lambert Run.

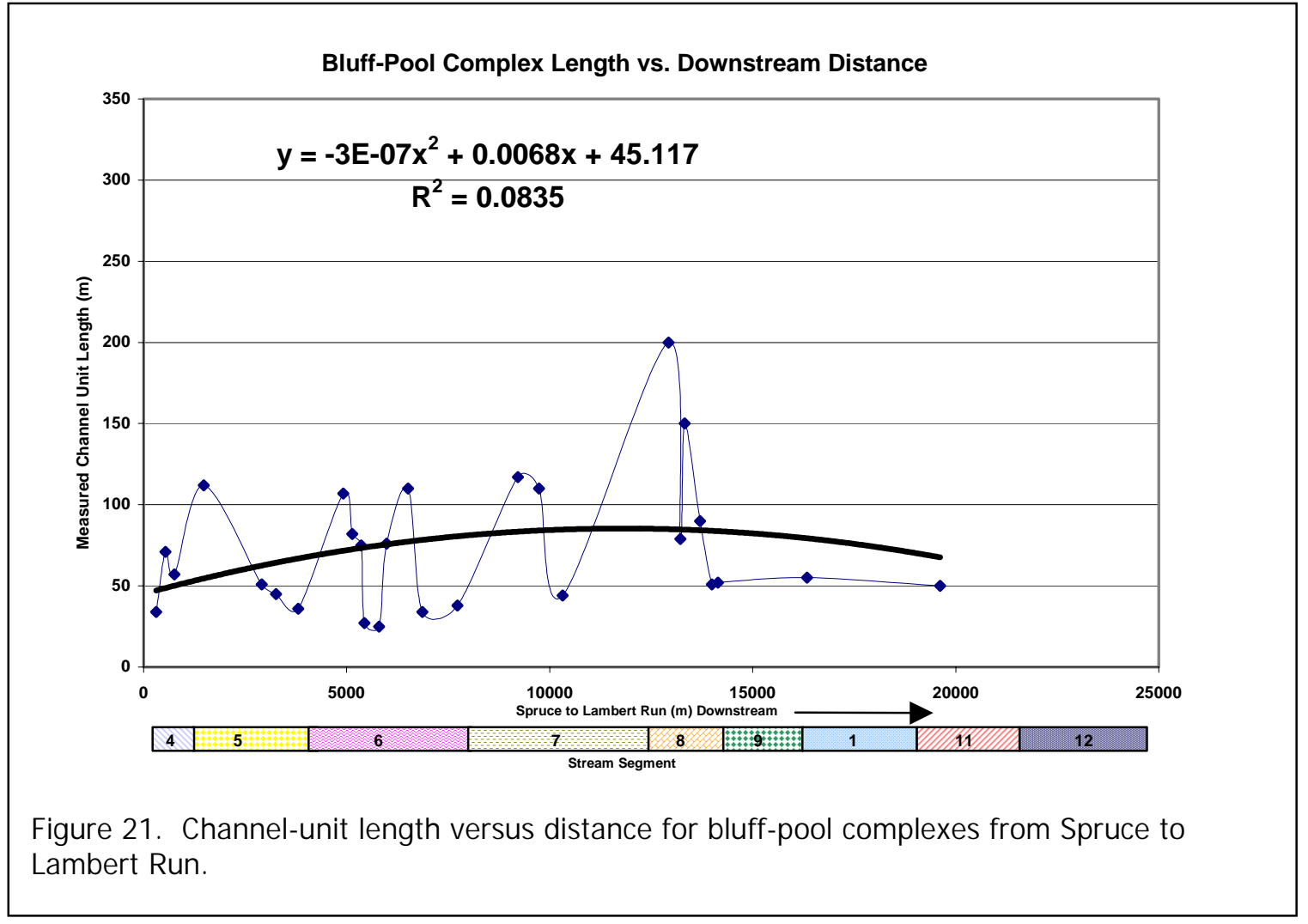




\section{Channel Unit Area}

Channel-unit area (Figure 22) increases in the downstream direction.

High-area channel units are predominant in segments 10,11 , and 12 , although two high-area glides occur near the boundary between segments 6 and 7 .

Channel-unit area trends for each channel-unit type are illustrated in Figures 23 through 28. Glides, riffle-glide complexes, and riffle-run complexes constitute the largest areas within the stream with several individual units far exceeding $1500 \mathrm{~m}^{2}$. Several large riffles occur in the lower segments, 11 and 12.

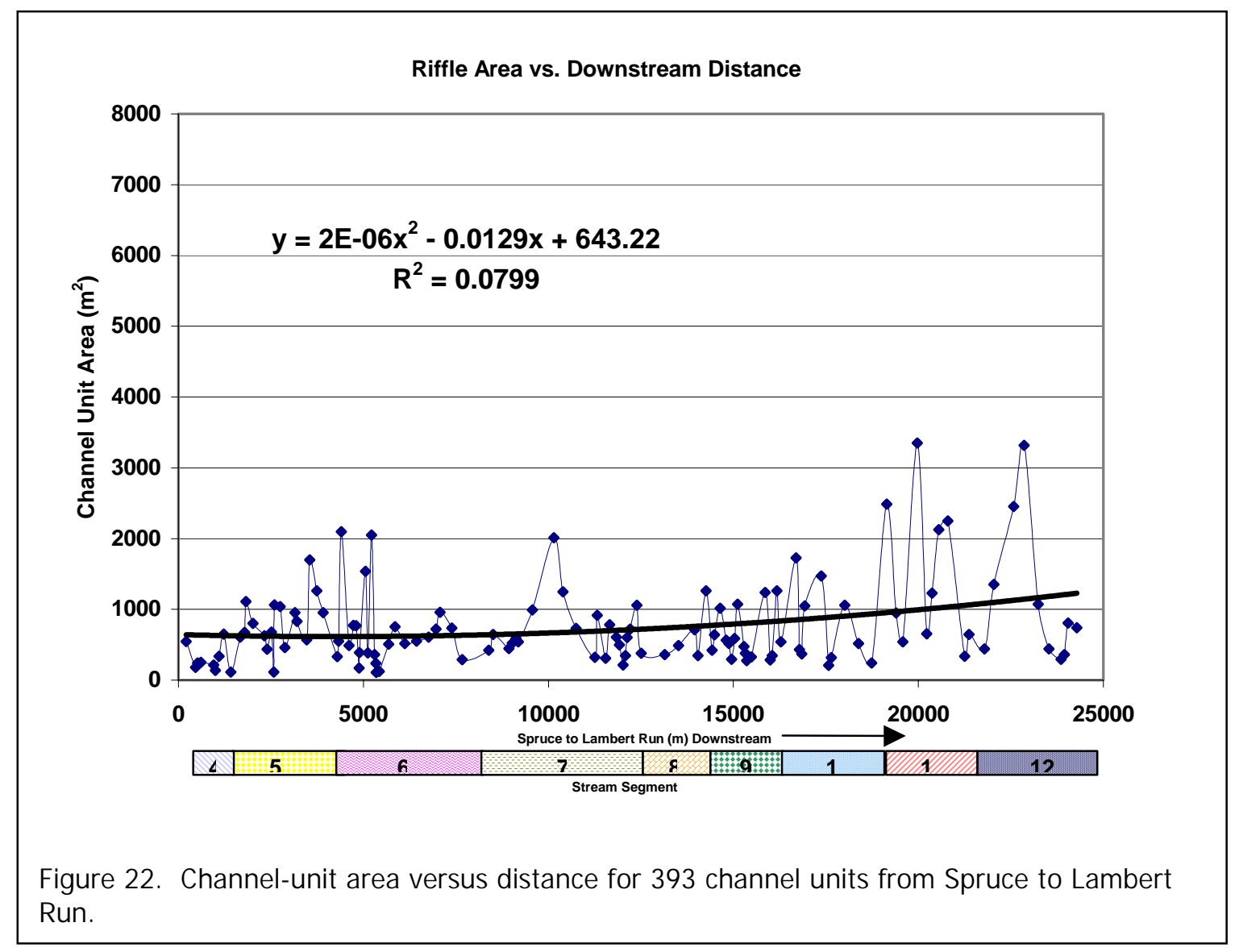



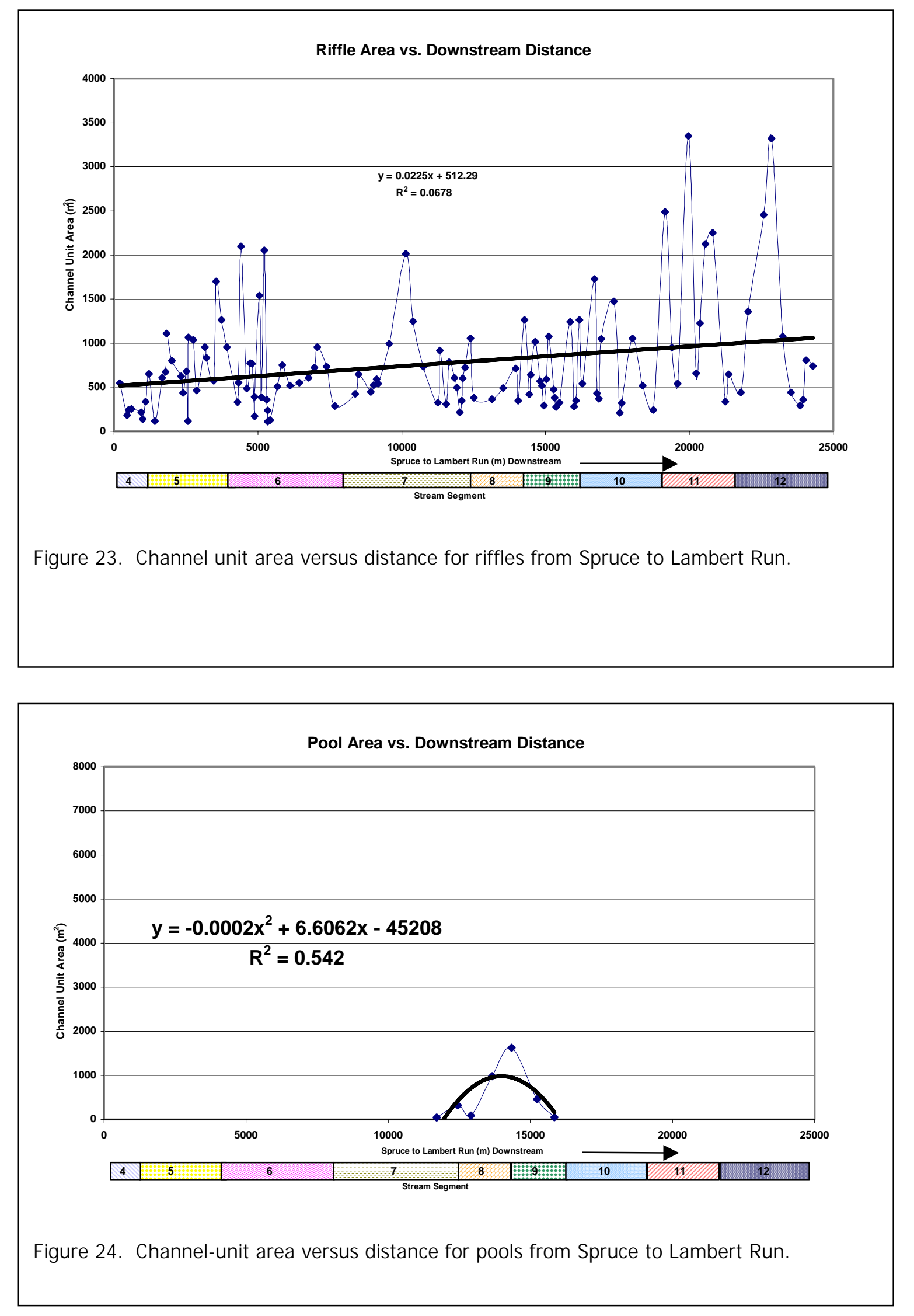


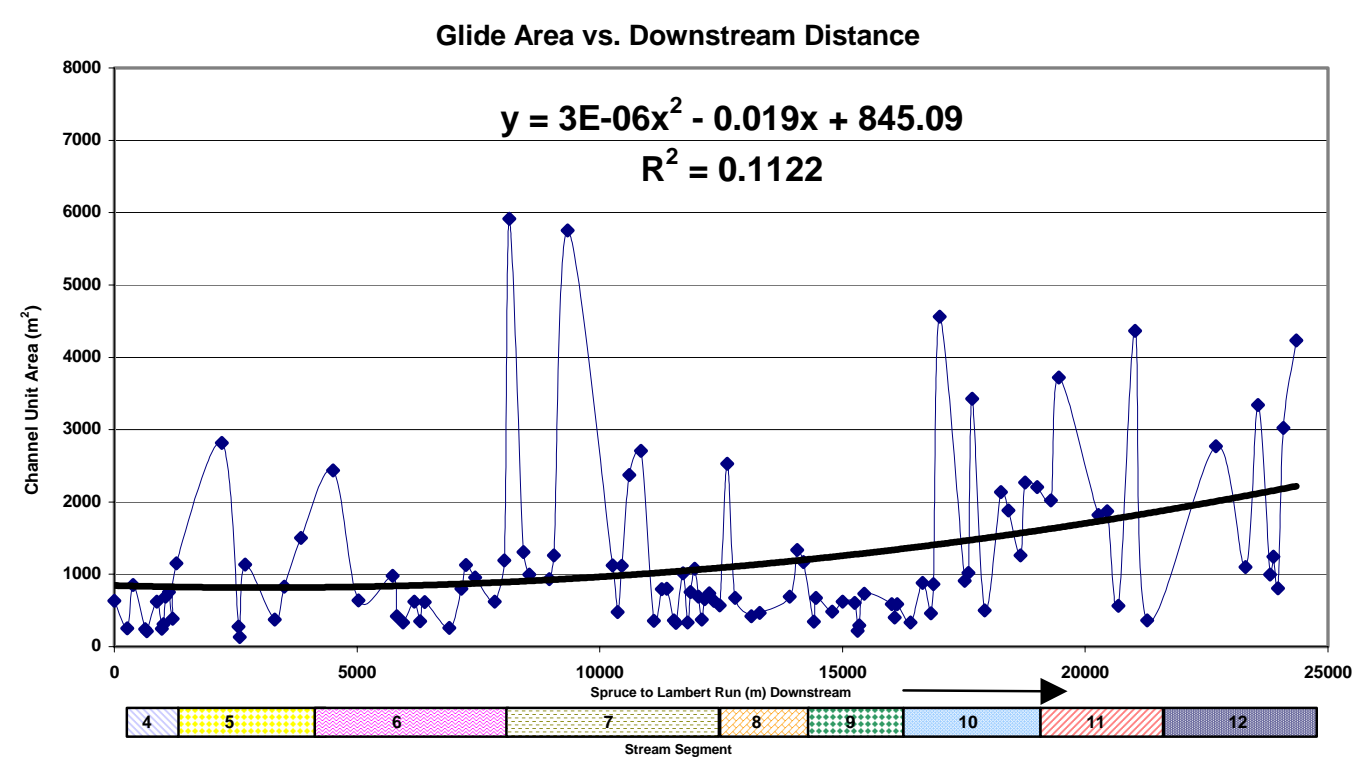

Figure 25. Channel-unit area versus distance for glides from Spruce to Lambert Run.

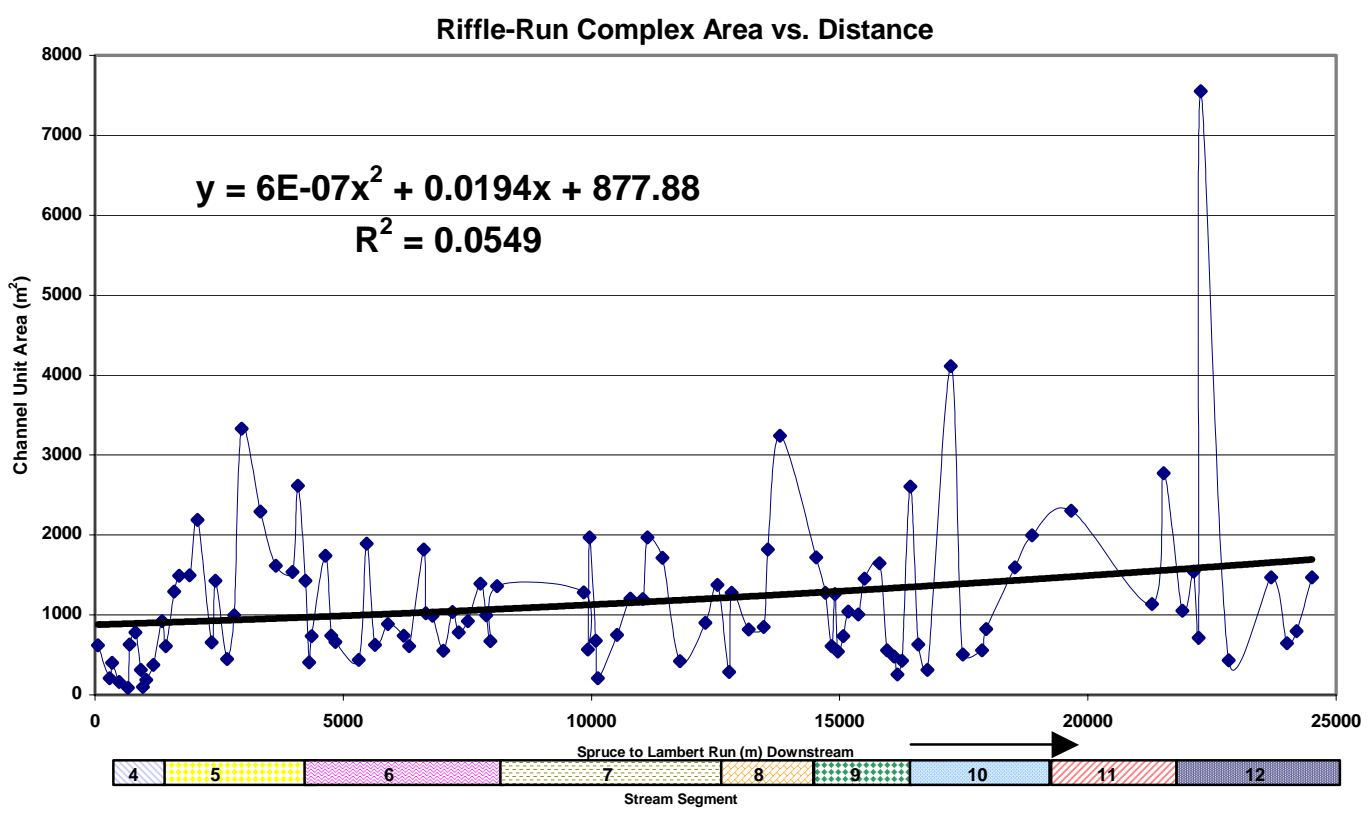

Figure 26. Channel-unit area versus distance for riffle-run complexes from Spruce to Lambert Run. 

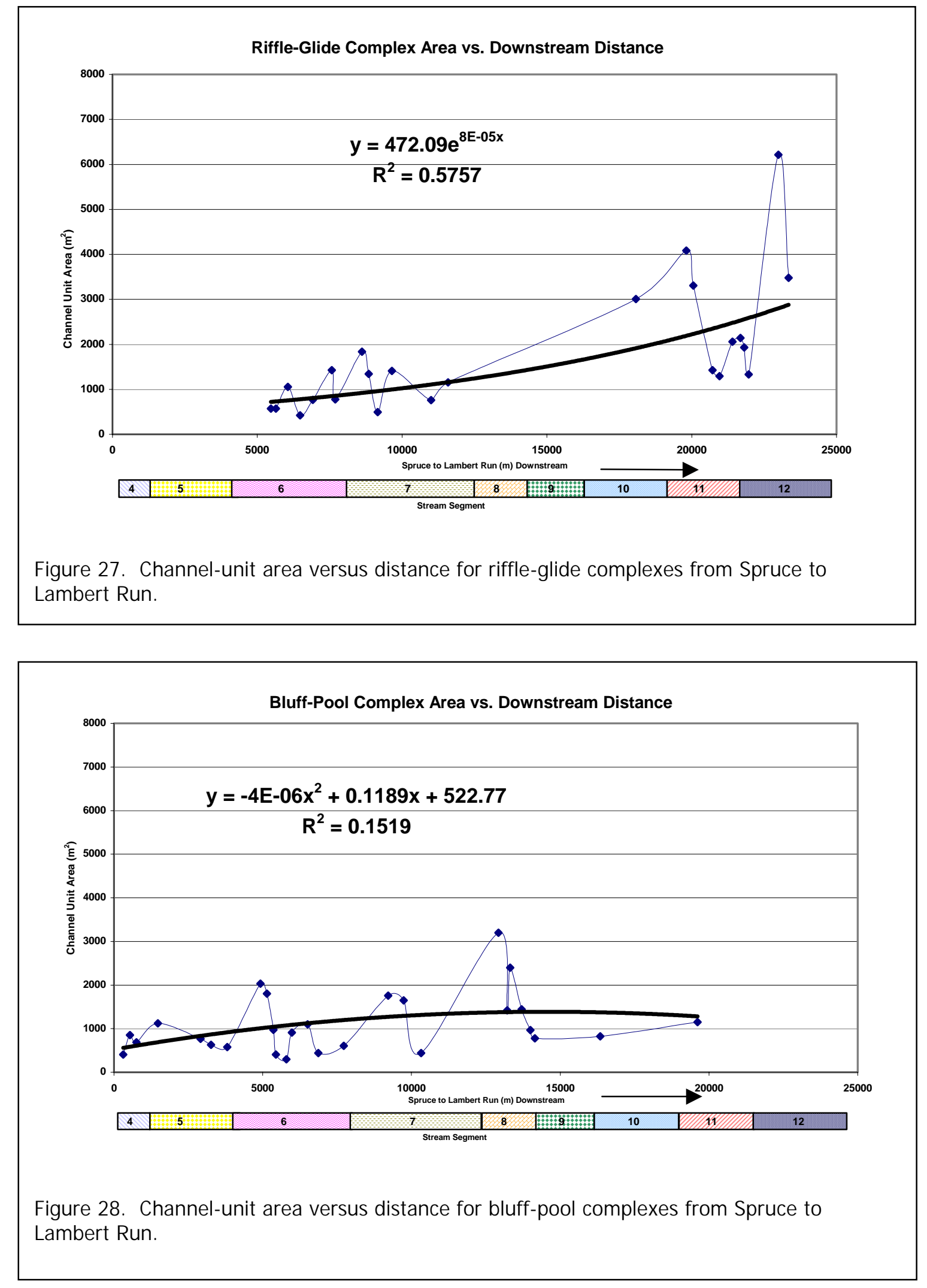


\section{Maximum Depth}

Channel-unit maximum depth (Figure 29) also increased downstream. The greatest variation from the mean maximum depth occurs in the middle segments $7,8,9,10$, and 11 . Maximum depths less than $0.5 \mathrm{~m}$ are less frequent in the lower segments 11 and 12. Maximum depth information for individual channel unit types is illustrated in Figures 30 through 35. Most pools are deeper than $0.7 \mathrm{~m}$. Pools, bluff-pools, and riffle-run complexes contain the deepest sections of stream with a mean maximum depth of $0.8 \mathrm{~m}$. Five maximum-depth anomalies above $1.2 \mathrm{~m}$, two riffle-run complexes and three bluff-pool complexes, occur near the boundary of segments 5 and 6 . Riffles constitute the shallowest sections of the stream with a mean maximum depth of $0.5 \mathrm{~m}$.

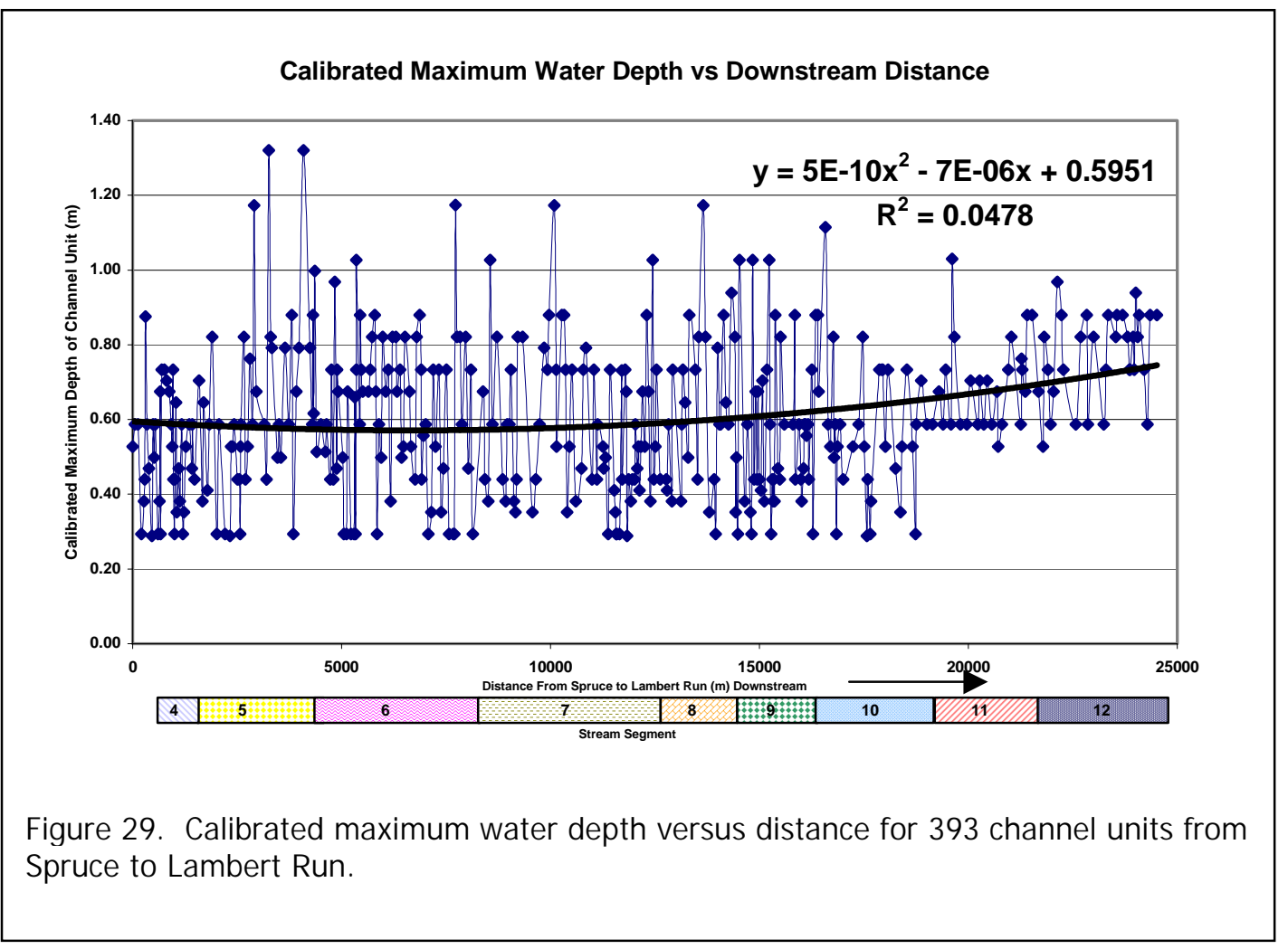



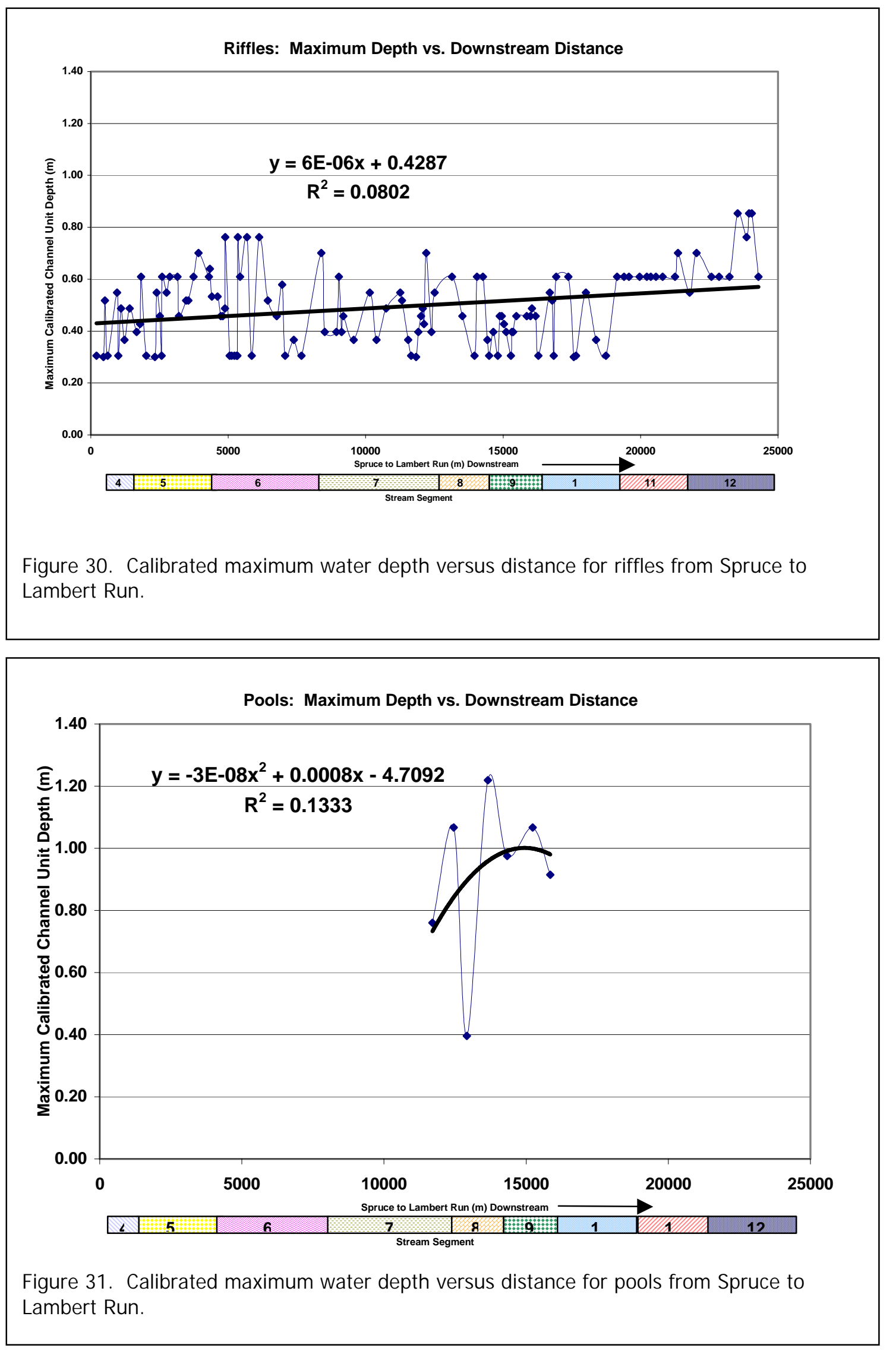


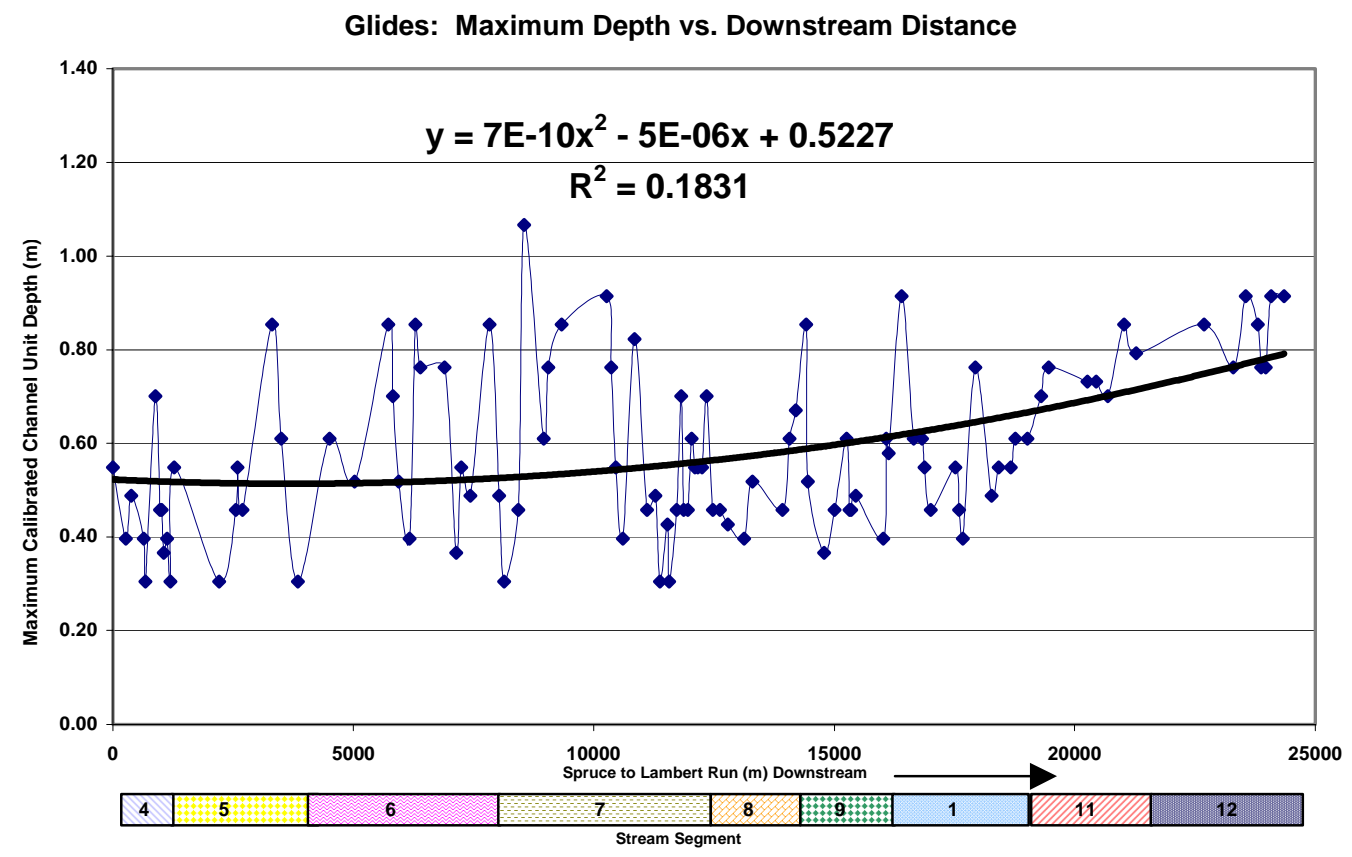

Figure 32. Calibrated maximum water depth versus distance for glides from Spruce to Lambert Run.

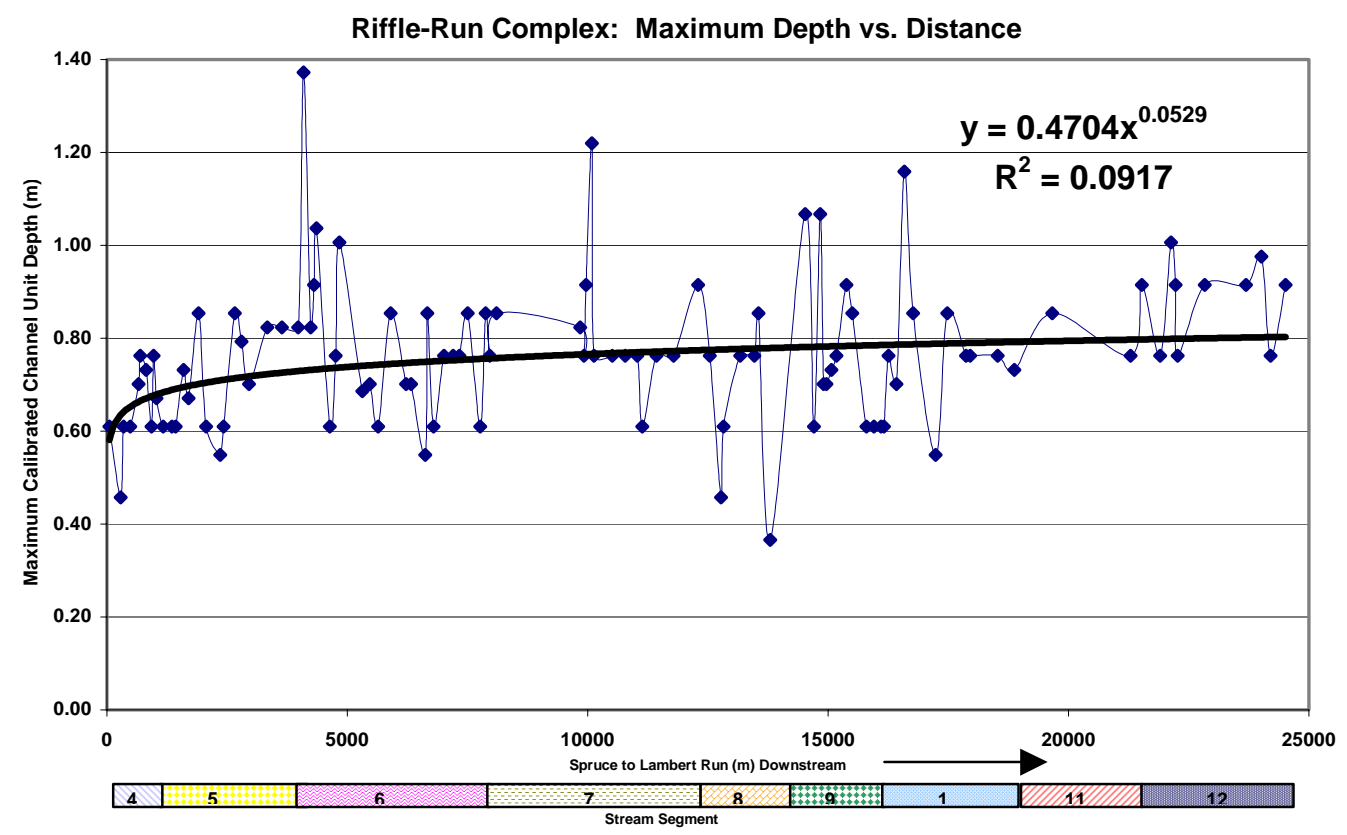

Figure 33. Calibrated maximum water depth versus distance for riffle-run complexes from Spruce to Lambert Run. 


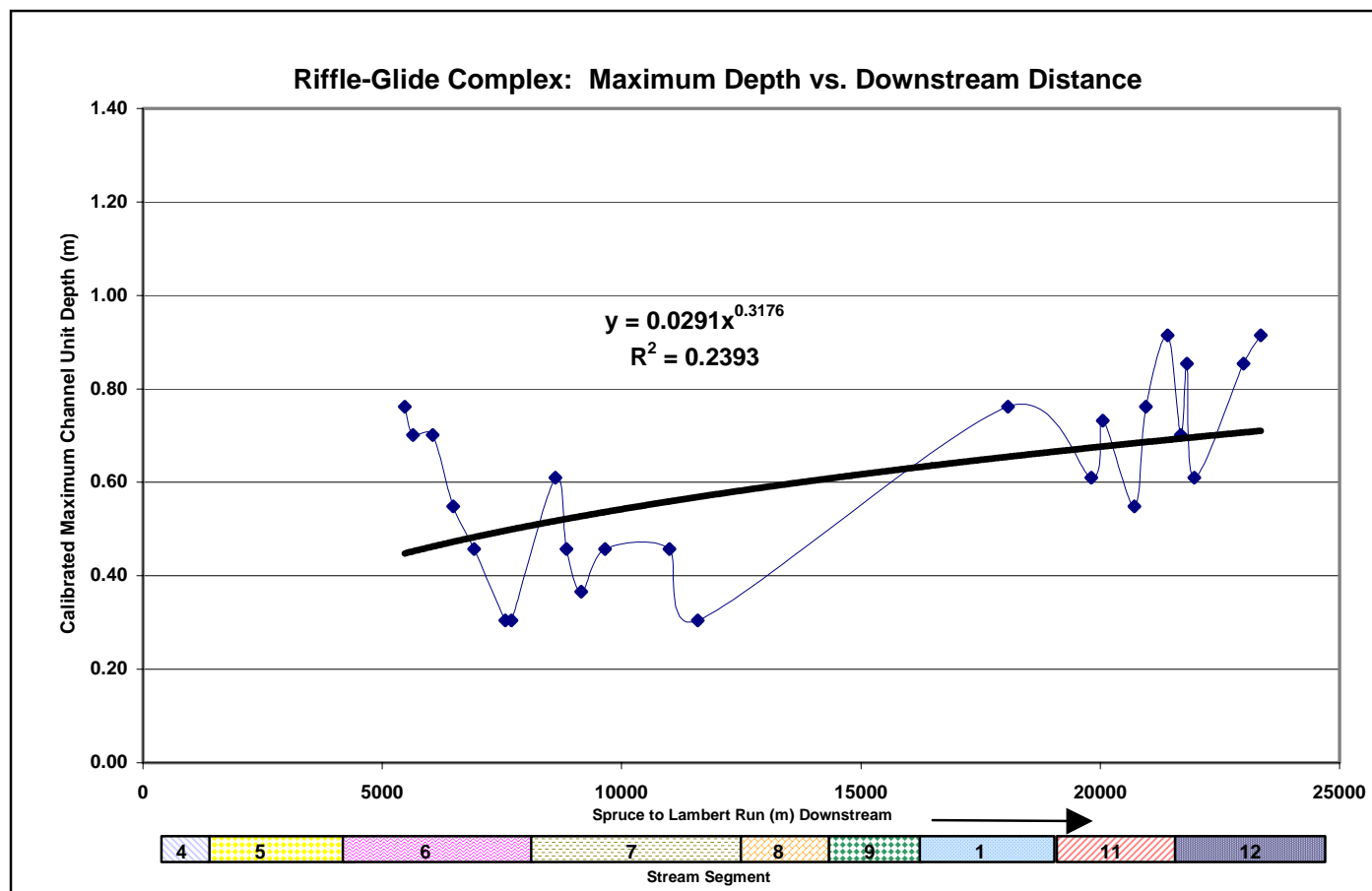

Figure 34. Calibrated maximum water depth versus distance for riffle-glide complexes from Spruce to Lambert Run.

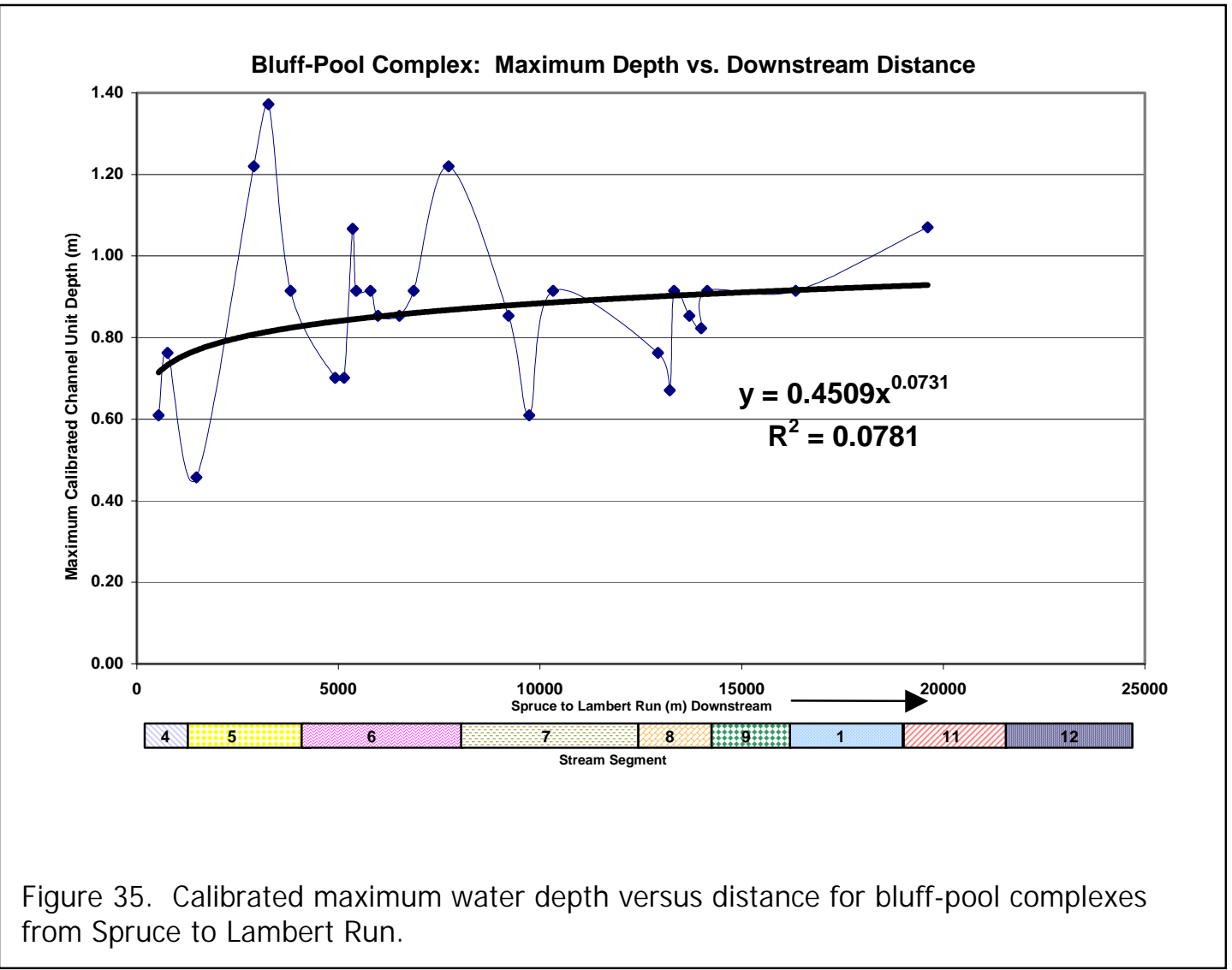




\section{Channel Unit Proportion}

The proportion of channel unit types per stream segment is illustrated in Figure 36. The proportions of pools, riffle-glide complexes, and bluff-pool complexes vary greatly from segment to segment. Significantly larger populations of riffle-glide complexes occur in segment 11. Channel units tend to have larger areas in downstream segments, so more units occur higher in the drainage and fewer occur downstream. Riffles, glides, and riffle-run complexes dominate the channel unit abundance with at least 8 per segment. Bluff pools are most abundant in the upper segments 4, 5, 6, and 8 . Riffle-glide complexes uncommon or may be absent in segments $4,5,8$, and 9 .

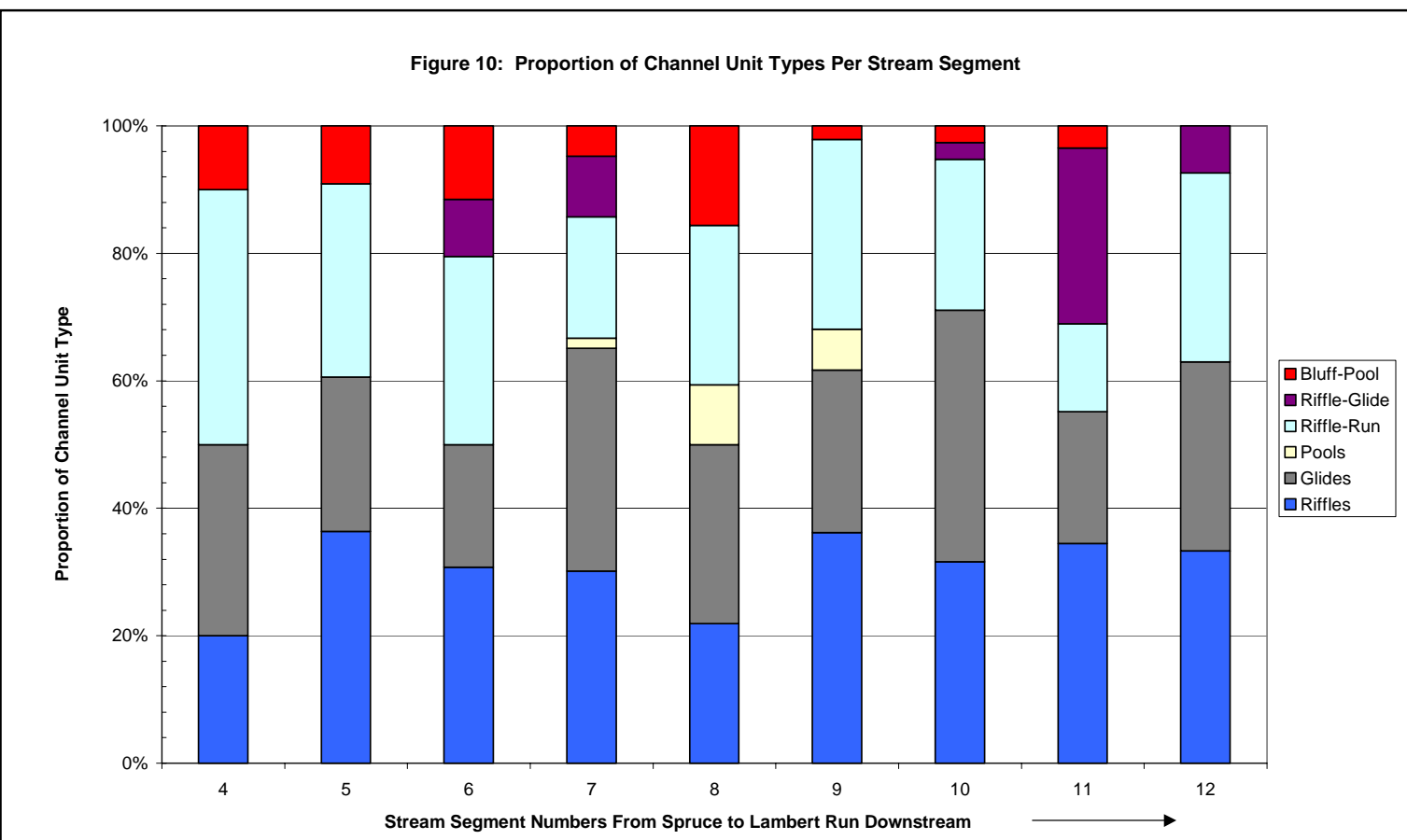

Figure 36. The proportion of channel unit types per stream segment. 
Riffles constitute 32 percent of the total channel unit area, riffle-run complexes and glides make up 26 percent each, bluff-pool complexes constitute 7 percent, riffle-glide complexes 6 percent, and true pools make up 2 percent of the total channel unit area. True pools are very uncommon and were only observed in channel units 7, 8, and 9. Pools and complexes are good to excellent fish habitat and comprise 69 percent of the total stream area. Riffles and glides are considered fair to poor fish habitat quality and constitute 31 percent of the total stream area.

\section{Large Woody Debris (LWD)}

Large woody debris (LWD) data for each channel unit are listed in Appendix III. LWD was categorized for this study according to size classes (1-6), segregated by length and diameter. Class 1 indicates short length $(<2 \mathrm{~m})$ and small diameter $(<3.5 \mathrm{~cm})$, class 2 indicates short length and medium diameter $(3.5 \mathrm{~cm}-21.0 \mathrm{~cm})$, class 3 is short length and large diameter $(>21 \mathrm{~cm})$, class 4 is long length ( $>2 \mathrm{~m}$ ) and small diameter, class 5 is long length, medium diameter, and class 6 is long length and large diameter. A total abundance of LWD was estimated to 2926 pieces. The LWD data population decreases in the downstream direction and indicates LWD retention in the upper segments. Headwater segments 4 and 6 have the highest relative abundance of LWD. This abundance can be attributed to smaller flood flows than downstream segments and a narrower channel width where stream bank lodging of LWD can occur perpendicular to the channel. The greatest local abundance of in-stream LWD 
occurs in a riffle-run complex in segment 9 , channel unit\#260, approximately

$14,500 \mathrm{~m}$ downstream of Spruce (measured along the sinuosity of the channel), where a downed tree confines and partially dams the channel. The debris dam and alluvial bar add morphologic and hydraulic heterogeneity to the unit and help to classify the flow complexity.

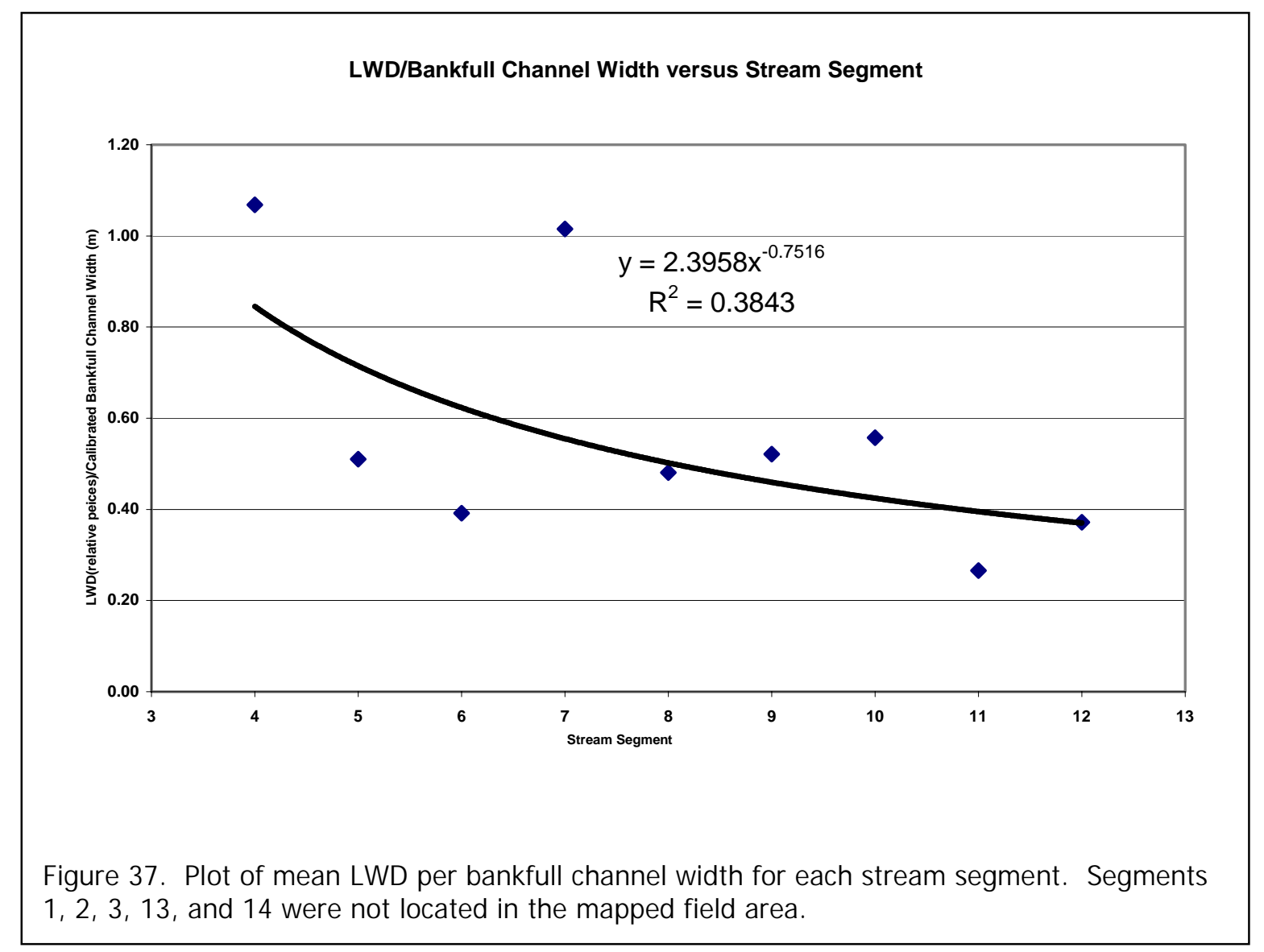




\section{Survey Results}

High-resolution survey data was acquired for a $288 \mathrm{~m}^{2}$ section above Black Run with the intent of using these data for classification according to Rosgen (1994) (Figure 38). The real-time stage was $5.30 \mathrm{ft}$ at Cheat Bridge during the survey. The survey data was imported into Land Desktop 2002 and yields the general stream geometry for the survey reach illustrated in Appendix IV. The survey neglected to include enough data to construct a true Rosgen stream classification. A future study may find the data included in Appendix IV useful.

\section{Rosgen Classification}

Shavers Fork was classified following the Rosgen (1994) method, but all data were compiled from remotely sensed DOQQ imagery within a GIS except for dominant substrate, which was determined in the field. The reach directly above the survey reach (Figure 38) is categorized as a C3 Rosgen-type channel based on a sinuosity of 1.38 , average entrenchment ratio of 4.80 , and an average gradient of 0.0037 . The Shavers Fork bedload from Spruce to Cheat Bridge is predominantly cobble. 


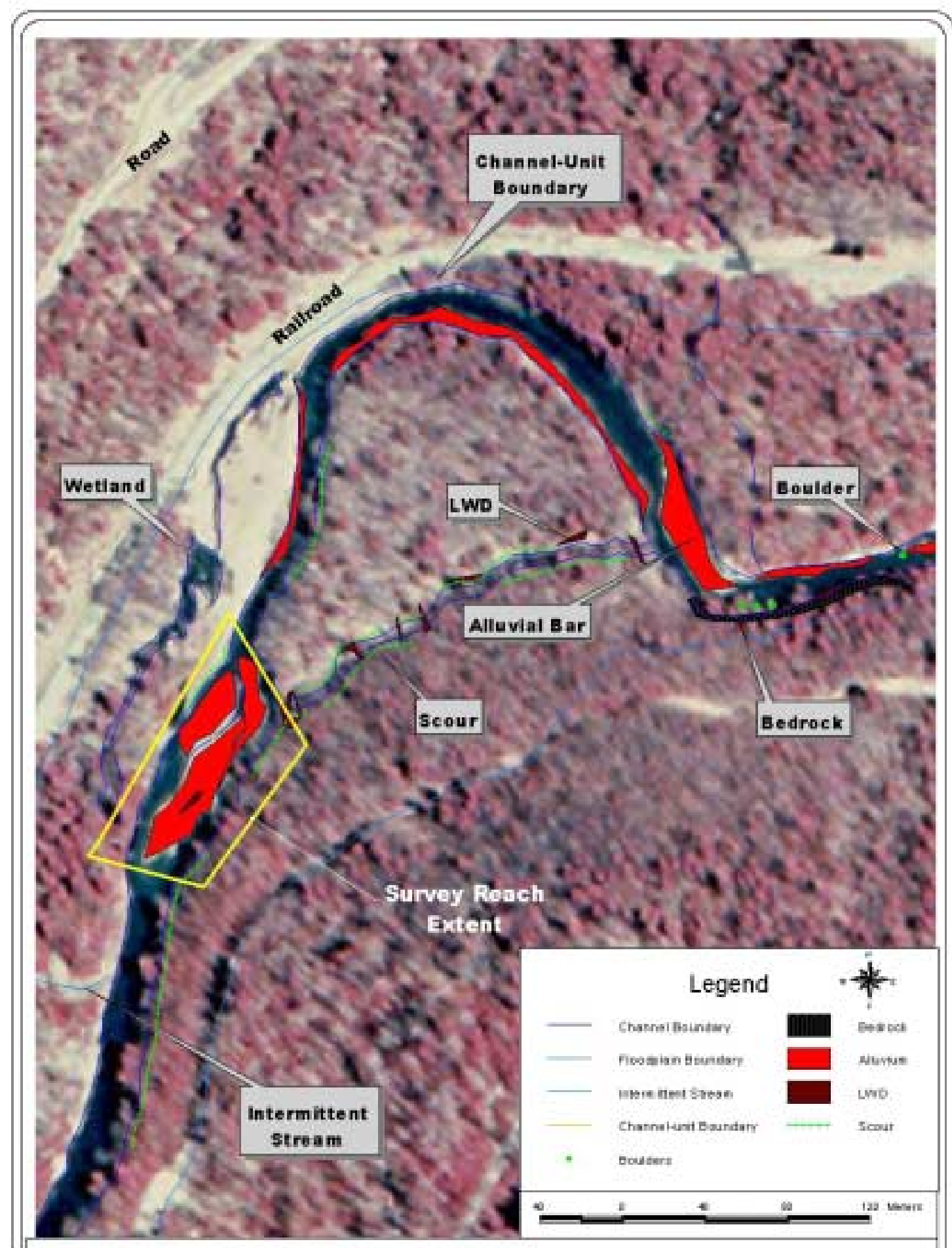

Figure 38. A DOOQ map of the survey area above Black Run showing the geomorphology and channel-unit boundaries. The land colors are the result of digital infrared photography during leaf-off.' This map was compiled by Ryan Gaujot. 


\section{Discussion}

The physical components of the Shavers Fork watershed support the fishery, and help it to maintain it's current state of integrity within a larger ecological system. The overall geometry of the Shavers Fork channel may have been influenced by anthropogenic activity within the watershed, but more historical landscape and channel data must be researched. If a sustainable fishery is (or will be?) the goal for future remediation designs, analysis of physical disequilibria within the watershed may identify target areas and research questions that need to be addressed. A researcher must question where is the stream broken and what is the scale of the problem? Are the problems in the watershed or the channel? What does the watershed need? I hope to give insight into these questions in the following section.

\section{Morphologic Disequilibria}

Acidification of headwater streams occurs through atmospheric deposition on acidic bedrock and soils in upper headwater tributaries. Contour surface mining has occurred in the upper headwater segments of Black Run and Lambert Run. With regard to the physiography and elevational constraints of this fifth order stream, Shavers Fork is relatively wide, shallow, and low gradient. The gradient is generally consistent from Spruce to Lambert Run, averaging 0.0037 . Higher gradient reaches occur below tributary confluences and in the upper- 
segments at bedrock constrictions. Bedload caliber and volume reflects the local bedrock geology. The most noticeable bedload caliber disequilibria occurs above tressels, where finer grained sediment accumulates, due to aggradation above the man-made hydraulic constrictions.

Erosion and deposition are a natural phenomenon of the stream and its continuous development and balance between driving and resisting forces. Alluvial bars are abundant throughout all segments, and are expected to migrate as the stream continually develops with time. Most scour develops on the inside of alluvial point bars located on meander bends. Bank instability and scour also occurs in areas opposite of streamside railroad contact. Current sources of human-induced sedimentation in Shavers Fork include maintenance of the railroad grade, and development of buildings, ski slopes, and roads near Snowshoe and adjacent areas (Figure 3 and 4).

Today, certain anthropogenic features within the floodplain disconnect the mainstem from natural adjacent features and influence the Shavers Fork channel. The railbed laterally constrains the channel in many reaches. The bank along the railroad is generally armored with riprap that locally erodes when the stream flows at high velocity over these anthropogenic structures. With the loss of floodplain area, higher flows are constrained within the remaining floodplain, developing the channel into a straighter, shorter stream that moves faster. Appropriate physical characteristics of a stream adequate for a fishery include dynamic, complex channels as well as sufficient vegetation to provide 
shade and cover, trap sediments, and dissipate flood effects. The bank is the channelward limit of the perennial vegetation (Furtman, 1999). Adequate woody debris and other biotic materials provide shelter for fish, and the organic material serves as food for aquatic insects at the base of the food chain (Wood, 1998). Construction of the railroad has significantly affected the riparian canopy on the floodplain. The hydraulic complexity of the vegetated stream bank has been lost because of railroad construction, allowing faster flow than is natural. The lack of riparian cover has amplified the thermal temperature problem in the mainstem due to the lack of stream shading. Channel units with poor riparian cover and eastern to southeastern channel aspects are exposed to direct sunlight, and are subject to stream heating. The channel width of the Shavers Fork mainstem is wider than the height of most tree trunks along the stream banks, resulting in flushing of downed in-stream LWD during high flow events decreasing the total heterogeneity in the system. Fortunately, in-situ root masses (rootwads) are abundant and provide bank stabilization.

\section{Channel Unit Disconformities}

The abundance of specific channel-unit types within different stream segments gives insight into the total in-stream heterogeneity of Shavers Fork. Abrupt changes in the flow dynamics of Shavers Fork occur only locally. Within the field area, flow velocity is low until a significant change in gradient or instream and/or riparian features constrict the channel. Heterogeneous units 
occur when gradient or channel characteristics change or when in-stream features inhibit streaming flow. Most heterogeneity in the upper Shavers Fork occurs in the higher elevation segments 5 and 6 . Below segment boundary 6 , the channel dramatically changes in geometry. The widening of the channel near Second Fork, coupled with the additional flow from this major tributary, results in the downstream transport of habitat features that produce heterogeneity in the stream. As the stream widens below Second Fork, riparian tree-fall is less likely to be 'lodged' from bank to bank and clog the channel. Among the six different channel-unit types in Table 6, riffles, pools, and glides have homogeneous flow characteristics. Channel-unit complexes (Table 6) involve several 'blended' channel units and have more heterogeneous flow characteristics. Channel unit complexes usually contain one or more mapped habitat features (alluvial deposits, scour, bedrock outcrops, boulders $>1.5 \mathrm{~m}$, or LWD) that control the extent of heterogeneity and the hydraulic component of flow.

\section{Remediation Suggestions}

The upper Shavers Fork is a reference headwater stream in the Appalachian Highlands. It's morphologic and channel-unit attributes provide a blend of flow complexities and habitat characteristics that enhance the stream's authenticity of a high elevation West Virginia stream. 
If research goals are to rehabilitate and sustain a trout fishery, researchers must first understand Shavers Fork's history then assess the present condition of watershed and its influence on the Shavers Fork channel. Before researchers implement a remediation design they must be clear on the expected outcomes of the project, and assess whether the problems are in the watershed or the stream channel. A hierarchical organization of the landscape at different scales can help to identify specific areas that need attention on Shavers Fork, then remediation recommendations and designs can address the actual components in the stream that are broken. Some channel components need to be considered to enhance future rehabilitation designs: high elevation, low gradient, naturally homogenous, natural lateral channel migration within the floodplain, lateral constriction of the floodplain by the railroad, and present and future headwater drainage development.

Stream reaches of low complexity below Second Fork may contain target sites for in-stream rehabilitation projects on the mainstem, in particular, reaches in contact with the railroad grade that have developed intermittent channels on the inside of meander bends. Remediation should address components of the watershed that facilitate or inhibit erosion and deposition rates. LWD and rootwads placed in heavily scoured reaches could provide bank stability and provide in-stream habitat cover for fish. Natural recovery of the upper Shavers Fork fishery may also be accomplished if measures are taken to promote riparian canopy growth without disrupting rare plant species that exist in natural open 
floodplain areas. Riparian restoration along the railroad grade would also facilitate fishery rehabilitation and recovery of the lotic system. Remediation designs could be enhanced through research on tributary and mainstem interactions, and linkages between healthy components of the watershed and low quality habitat.

Land-use activities can influence the spatial heterogeneity and connectivity of physical habitats and ultimately affect functional interactions among terrestrial and aquatic elements. In light of these relationships, scientists need to focus on ways to model environmental heterogeneity and critical biological processes that will lead to insights into fishery sustainability and effective rehabilitation measures. 


\section{References Cited}

Clarkson, R.B., 1964, Tumult in the mountains, lumbering in West Virginia 17701920, McClain Printing Company, Parsons, West Virginia, p. 86-91.

Compton, R.R., 1985, Geology in the Field, J ohn Wiley and Sons, New York, p. 112-134.

Cushing, C.E. 1994, The conception and testing of the river continuum concept, J ournal of North American Benthological Society, v. 11, n. 2, 225-229.

Deike, G., 2000, The River Roots, Newsletter of the Shavers Fork Coalition, v. 4, n. 1, p. 1-5.

Flegel, D.G., 1992, Soil Survey of Pocahontas County, West Virginia, Natural Resource Conservation Service, 1-152.

Furtman, M., 1999, Habitat: Thinking like a river, Trout, v. 89. p. 13-23.

Hack, J. T., 1960, Interpretation of erosional topography in humid temperate regions: American Journal of Science, v. 258-A, p. 80-97.

Hack, J.T., 1965, Geomorphology of the Shenandoah Valley, Virginia and West Virginia, and origin of the residual ore deposits: U.S. Geological Survey Professional Paper 484, p. 84.

Hack, J.T., 1975, Dynamic equilibrium and landscape evolution: perspective: in Melhorn, W.N., and Flemal, R.C., editors, Theories of landform development, Binghamton, New York, Publications in Geomorphology, p. 91-102.

Hawkins, C.P.; Kershner, J.L.; Bisson, P.A.; Bryant, M.D.; Decker, L.M.; Gregory, S.V.; McCullough, D.A.; Overton, C.K.; Reeves, G.H.; Steedman, R.J .; Young, M.K., 1993, A hierarchical approach to classifying stream habitat features, Fisheries, v. 18, n. 6, p. 3-11.

Hocutt, C.H., 1979, Drainage evolution and fish dispersal in the central Appalachians, Geological Society of America Bulletin, Part II, v. 90, p. 197-234.

Keller, E.A., 1978, Rhythmic spacing and origin of pools and riffles, Geological Society of America Bulletin, v. 89, p. 723-730. 
Kite, J.S., 1996, Guideline for Preparation of Surficial Geology Quadrangle Maps for West Virginia and Adjacent States, A Working Document, Dept. of Geology and Geography, West Virginia University, 19 p.

Maxwell, J.R.; Edwards, C.J .; J enson, M.E.; Paustain, S.J .; Parrott, H.; Hill, D.M., 1995, A hierarchical framework of aquatic ecological units in North America, Gen. Tech. Rep. NC-176, St. Paul, MN; US Department of Agriculture, Forest Service, North Central Forest Experimental Station, 72 p.

Minshall, G.W.; Cummings, K.W.; Peterson, R.C.; Cushing, C.E.; Bruns, D.A.; Sedal, J.R.; Vannote, R.L., 1985, Developments in stream ecosystem theory, Canadian J ournal of Aquatic Science, v. 42, p. 1045-1055.

Minshall, G.W, 1996, Bringing biology back into water quality assessments, Freshwater Ecosystems: revitalizing educational programs in limnology, Committee in Inland Aquatic Ecosystems, p. 289-324.

Montgomery, D.R., 1993, Channel classification, prediction of channel response, and assessment of channel condition, Report prepared for the SHAMW committee of Washington State Timber/Fish/Wildlife Agreement, University of Washington, Seattle, Washington, $67 \mathrm{p}$.

Montgomery, D.R., and Buffington, J.M., 1997, Channel-reach morphology in mountain drainage basins, Geological Society of America Bulletin, v. 109, p. 596611.

Morisawa, 1968, Streams, their dynamics and morphology, McGraw-Hill Book Company, p. 29-40.

Petty, T.J., 1999, Habitat suitability and factors influencing stream fish community structure within the upper Shavers Fork drainage: A hierarchical approach, A research proposal to the West Virginia Department of Natural Resources, 9 p.

Price, P.H., Reger, D.B., 1929, Pocahontas County Report, West Virginia Geological Survey, p. 1- 425.

Pyle, R.E., Beverage, W.W., Yoakum, T., Amic, D.P., Hatfield, W.F., McKinney, D.E., 1982, Soil survey of Randolph County, West Virginia, U.S. Soil Conservation Service, $167 \mathrm{p}$.

Orth, D.J . and Maughan, O.E., 1982, Evaluation of the incremental methodology for recommending in-stream flows for fishes, Transactions of the American Fisheries Society, v. 111, n. 4, 413-445. 
Rabini, C.F., Jacobson, R.B., 1993, The importance of fluvial hydraulics to fishhabitat restoration in low-gradient alluvial streams, Freshwater Biology, v. 29, p. 211-220.

Reger, D.B., Teets, D.D., 1918, Barbour, Upshur, and Western Randolph County Report, 267 p.

Rosgen, D.L., 1994, A classification of natural rivers, Catena, v. 22, p. 169-199.

Rosgen, D.L., 1996, Applied river morphology, Wildland Hydrology, Pagosa Springs Colorado.

Schlosser, Isaac, J., 1991, Stream Fish Ecology: A landscape perspective, BioScience, v. 41, n. 10, p. 704-712.

Sherlock, S.M., 1997, The use of point-source applications of limestone aggregate fines for treatment of acidic streams, Dissertation submitted to the Eberly College of Arts and Sciences, Department of Geology and Geography, West Virginia University, p. 14-19.

Vannote, R.L., Minshall, G.W., Cummings, K.W., Sedall, J.R., Cushing, C.E., 1980, The river continuum concept. Canadian J ournal of Fish and Aquatic Science, $v$. 37, p., 130-137.

Whiting, P.J ., and Bradley, J.B., 1993, A process-based classification system for headwater streams: Earth Surface Processes and Landforms, v. 18, p. 603-612.

Wiley, J.B., Atkins, J.T., Tasker, G.D., 2000, Estimating magnitude and frequency of peak discharges for rural, unregulated, streams in West Virginia, U.S. Department of the Interior, U.S. Geological Survey, Water-Resources Investigations Report 00-4080, 18 p.

Williams, J.E., Wood, C.A., Dombeck, M.P., 1997, Watershed Restoration:

Principles and Practices, American Fisheries Society ISBN: 1-888569-04-2, 74 p.

Wolman, M. Gordon, and Miller, John P., 1960, Magnitude and frequency of forces in geomorphic processes: J ournal of Geology, v. 68, p. 54-74.

Wood, C.A., Williams, J.E., Dombeck, M.P., 1998, The art and science of stream restoration: Trout, v. 70, p. 31-36. 


\section{Additional Bibliography}

Bruns, D.A., Wiersma, G.B., Minshall, G.W., 1991, Problems of long-term monitoring of lotic ecosystems, In Penelope Firth and Stuart G. Fisher eds., Global Climate Change and Freshwater Ecosystems, Springer-Verlag, New York, p. 285-307.

Clayton, J.T., Dannaway, E.S., Menendez, R., Rauch, H.W., Renton, J.J ., Sherlock, S.M., Zurbuch, P.E., 1998, Application of limestone to restore fish communities in acidified streams, North American J ournal of Fisheries Management, v. 18, p. 347-360.

Costa, J.E., O'Connor, J.E., 1995, Geomorphically effective floods, Natural and Anthropogenic Influences in Fluvial Geomorphology, Geophysical Monograph 89, p. 45-56.

Dilloff, C.A., Hankin, D.G., Reeves, G.H., 1993, Basinwide estimation of habitat and fish populations in streams, USDA Forest Service General Technical Report SE-83, Ashville, NC: Southeastern Forest Experiment Station, 25 p.

Dilloff, C.A., Jennings, H.E., Owen, M.D, 1997, A comparison of basinwide and representative reach habitat survey techniques in three southern Appalachian Watersheds, North American J ournal of Fisheries Management, v. 17, p. 339347.

Dunham, J.B., Rieman, B.E., 1999, Metapopulation structure of bull trout: influences of physical, biotic, and geometrical landscape characteristics, Ecological Applications, v. 9, n. 2, p. 642-655.

Dunne, Thomas, and Leopold, Luna B., 1978, Water in environment planning: San Francisco, W.H. Freeman and Company, 818 p.

Fausch, K.D., Northcote, T.G., Large woody debris and Salmonoid habitat in a small coastal British Columbia Stream, 1992, Canadian J ournal of Fish and Aquatic Science, v. 49, p. 682-693.

Fausch, K.D., Young, M.K., 1995, Evolutionary significant units and movement of resident stream fishes: a cautionary tale, American Fisheries Society Symposium, no. 17, p. 360-370.

Gowan, C., Fausch, K.D., 1996, Long-term demographic responses of trout populations to habitat manipulation in six Colorado streams, Ecological Applications, v. 6, n. 3, p. 931-946. 
Gresswell, R.E., Liss, W.J ., Larson, G.L., Bartlein, P.J., 1997, Influence of basinscale physical variables in life history characteristics of cutthroat trout in Yellowstone Lake, North American J ournal of Fisheries Management, v. 17, p. 1046-1064.

Hankin, D.G., 1984, Multistage sampling designs in Fisheries Research: applications in small streams, Canadian J ournal of Fisheries and Aquatic Science, v. 41 , p. $1575-1591$.

Hankin, D.G., Reeves, G.H., 1998, Estimating total fish abundance and total habitat area in small streams based on visual estimation methods, Canadian J ournal of Fisheries and Aquatic Science, v. 45, p. 834-843.

Hanski, I., 1999, Habitat connectivity, habitat continuity, and metapopulations in dynamic landscapes, Oikos, v. 87, p. 209-219.

Hayes, D.B., Ferreri, C.P., Taylor, W.W., Linking fish habitat to their population dynamics, 1996, Journal of Fisheries and Aquatic Science, v. 53. (Suppl. 1), p. 383-390.

Hooke, R.L., 1999, Spatial distribution of human geomorphic activity in the United States: comparison with rivers, Earth Surface Processes and Landforms, v. 24, p. $687-692$.

Herrelson, C.C., Rawlins, C.L., Potyondy, J.P., Stream channel reference sites; an illustrated guide to field technique, 1994, USDA Forest Service General Technical Report RM-245, p. 4-6.

Hupp, Cliff R., 1988, Plant ecological aspects of flood geomorphology and paleoflood history, in Baker, Victor R., Kochel, R. Craig, and Patton, Peter C., editors, Flood Geomorphology: New York, John Wiley and Sons, p. 335-356.

Kite, J. Steven, Gebhardt, Terry W., and Springer, Gregory S., 2002, Slackwater Deposits as Paleostage Indicators in Canyon Reaches of the Central Appalachians: Reevaluation After the 1996 Cheat River Flood, in House, P. Kyle, and others, editors, American Geophysical Union Geophysical Monograph.

Knox, James C., 1977, Human impacts on Wisconsin stream channels: Annals of the Association of American Geographers, v. 67, p. 323-342.

Kozel, S.J., Hubert, W.A., Parsons, M.G., 1989, Habitat features and trout abundance relative to gradient in some Wyoming streams, Northwest Science, $v$. 63, n. 4, p. 175-182. 
Kruse, C.G., Hubert, W.A., 1997, Geomorphic influences on the distribution of Yellowstone cutthroat trout in the Absaroka Mountains, Wyoming, Transactions of the American Fisheries Society, v. 126, p. 418-427.

Kwak, T.J., Waters, T.F., 1997, Trout production dynamics and water quality in Minnesota streams, Transactions of the American Fisheries Society, v. 126, p. 35-48.

Leopold, Luna B., 1994, A view of the river, Harvard University Press, Cambridge Massachusetts and London, England, 293 p.

MacDonald, L.H., 1991, Monitoring guidelines to evaluate effects of forestry activities on streams in the Pacific Northwest and Alaska, U.S. EPA region 10 report No. CX-816031-01-0, Center for Streamside Studies in Forestry, Fisheries and Wildlife, College of Forest Resources/ College of Ocean and Fisheries Sciences, University of Washington, Seattle, Washington.

Marschall, E.A., Crowder, L.B., 1996, Assessing population responses to multiple anthropogenic effects: a case study with brook trout, Ecological Applications, v. 6, n. 1, p. 152-167.

McCarthy, M.A, Lindenmayer, D.B., 1998, Incorporating metapopulation dynamics of greater gliders into reserve design in disturbed landscapes, Ecology, v. 80, n. 2 , p. $651-667$.

McLaughlin, R.L., Grant, J.W.A., Kramer, D.L., 1994, Foraging movements in relation to morphology, water-column use, and diet for recently emerged brook trout (Salvenlinus fontinalis) in still-water pools, Canadian J ournal of Fisheries and Aquatic Science, v. 51, p. 268-279.

Miller, Andrew J., 1995, Valley morphology and boundary conditions influencing spatial patterns of flood flow, in Costa, J ohn E., Miller, Andrew J., Potter, Kenneth W., and Wilcock, Peter R., editors, Natural and anthropogenic influences in fluvial geomorphology (the Wolman volume), American Geophysical Union Geophysical Monograph 89, p. 57-82.

Minshall, G.W., Stream ecosystem theory: a global perspective, 1988, Journal of North American Benthological Society, v. 7, n. 4, p. 263-288.

Minshall, G.W., 1994, Stream-riparian ecosystems: rational and methods for basin-level assessments of management effects, In Jenson, M.E., Bourgeron, P.S., Eastside forest ecosystem health assessment, v. II: Ecosystem 
Management: Principles and Applications U.S. Forest Service Pacific Northwest research Station, Portland, Oregon p 153-177.

Minshall, G.W., Robinson, C.T., Royer, T.V., Rushforth, S.R., 1995, Benthic community structure in two adjacent streams in Yellowstone National Park five years after the 1988 wildfires, The Great Basin Naturalist, v. 55, n. 3, p. 193-200.

Osborne, L.L., Dickson, B., Ebbers, M., Ford, R., Lyons, J., Kline, D., Rankin, E., Ross, D., Sauer, R., Seelbach, P., Speas, C., Stefanavage, T., Waite, J., Walker, S., 1991, Stream habitat assessment programs in states of the AFS North Central Division, Fisheries, v. 16, n. 3, p. 28-35.

Rabeni, C.F., Sowa, S.P., 1996, Integrating biological realism into habitat restoration and conservation strategies for small streams, Canadian J ournal of Fish and Aquatic Science, v. 53, (Suppl. 1), p. 252-259.

Rogowski, A.S., 1996, GIS modeling of recharge on a watershed, Journal of Environmental Quality, v. 25, p. 463-474.

Rosenthal, W.D., Srinivasan, R., Arnold, J.G., Alternative river management using a linked GIS-hydrology model, 1995, Transactions of the American Society of Agricultural Engineers, v. 38, n. 3, p. 783-790.

Schlosser, I.J ., 1995, Critical Landscape attributes that influence fish population dynamics in headwater streams, Hydrobiology, v. 303, p. 71-81.

Sigafoos, R.S., 1964, Botanical evidence of floods and flood plain deposition: U.S. Geological Survey Professional Paper 485-A, 35 p.

Simonson, T.D., Lyons, J., Kanehl, P.D., 1994, Quantifying fish habitat in streams: transect spacing, sample size, and a proposed framework, North American J ournal of Fisheries Management, v. 14, p. 607-615.

Sophocleous, M., Koussis, A., Martin, J.L., Perkins, S.P., 1995, Evaluation of simplified stream-aquifer depletion models for water rights administration, Ground Water, v. 33, n. 4, p. 579-588.

Stringfield, V.T., Smith, R.C., 1956, Relation of geology to drainage, floods, and landslides in the Petersburg area, West Virginia, Geological and Economic Survey Report of Investigations No. 13, p. 1-18.

Swanberg, T.R., 1997, Movements of and habitat use by fluvial bull trout in the Blackfoot River, Montana, 1997, Transactions of the American Fisheries Society, v. 126, p. $735-746$. 
Webb, Robert H., Melis, Theodore S., Griffiths, Peter G., Elliott, John G., Cerling, Thure E., Poreda, Robert J., Wise, Thomas W., Pizzuto, James E., 1999, Lava Falls Rapid in Grand Canyon; effects of late Holocene debris flows on the Colorado River: U. S. Geological Survey Professional Paper 1591, 90 p., 1 sheet.

Welsh, S.A., Perry, S.A., 1997, Acidification and fish occurrence in the upper Cheat River drainage, West Virginia, J ournal of the American Water Resources Association, v. 33, n. 2, p. 423-429.

Wiegand, T., Moloney, K.A., Naves, J., Knauer, F., 1999, Finding the missing link between landscapes structure and population dynamics: a spatially explicit perspective, The American Naturalist, v. 154, n. 6, p. 605-627.

Wiley, M.J ., Kohler, S.L., Seelbach, P.W., 1997, Reconciling landscape and local views of aquatic communities: lessons from Michigan trout streams, Freshwater Biology, v. 37, p. 133-148.

Williams, G.P., 1984, Paleohydrologic equations for rivers, chapter 11 Developments and Applications of Geomorphology, Costa, J.E., Fleisher, P.J., Springer-Verlag Berlin Heidelburg, p. 343-366.

Winter, T.C., 1983, The interaction of lakes with variably saturated porous media, Water Resources Research, American Geophysical Union, v. 19, n. 5, p. 1203-1218.

Woessner, W.W., 2000, Stream and fluvial plain ground water interactions: rescaling hydrogeologic thought, Ground Water, v. 38, n. 3, p. 423-429.

Wolman, M. Gordon, and Miller, John P., 1960, Magnitude and frequency of forces in geomorphic processes: J ournal of Geology, v. 68, p. 54-74.

Zlotnik, V.A., Huang, H, 1999, Effect of shallow penetration and streambed sediments on aquifer response to stream stage fluctuations (analytical model), Ground Water, v. 37, n. 4, p. 599-605. 


\section{Appendix I}

\section{Channel} Unit \#

1

2

3

4

5

6

7

8

9

10

11

12

13

14

15

16

17

18

19

20

21

22

23

24

25

26

27

28

29

30

31

32

33

34

35

36

37

38

39

40

41

42

43

44
Distance

Downstream

From

Channel Unit

Gld

IgrRCa

Debris

Igr

Gld

IgrRCa

$\mathrm{BPCb}$

IgrRCa

Gld

IHgr

IgrRCa

IHgr

$\mathrm{BPCa}$

Igr

Gld

$\lg \mathrm{RCa}$

Gld

$\lg \mathrm{RCa}$

$\mathrm{BPCa}$

$\lg \mathrm{RCa}$

Gld

$\lg \mathrm{RCa}$

Igr

IgrRCa

Gld

Lgr

Gld

IgrRCa

Gld

Lgr

Gld

IgrRCa

Gld

Igr

Gld

$\lg \mathrm{RCa}$

Igr

IgrRCa

$\mathrm{BPCa}$

IgrRCa

$\lg r$

$\lg \mathrm{RCa}$

Lgr

IHgr

\section{Spruce (m)}

0
55
124

124

205

268

290

311

345

385

459

486

513

538

609

638

661

672

694

757

814

879

925

951

968

978

998

1010

1035

1052

1097

1124

1173

1198

1223

1275

1350

1416

1428

1479

1591

1667

1697

1790

1829

\begin{abstract}
Calibrated Measured
Maximum

Stream Channel Length Area Water
\end{abstract}

Segment Width $(m) \quad(m) \quad\left(m^{2}\right)$ Depth $(m)$

$\begin{array}{lllll}4 & 11.5 & 55 & 635 & 0.53\end{array}$

$\begin{array}{lllll}4 & 8.7 & 69 & 597 & 0.59\end{array}$

$\begin{array}{lllll}4 & 9.6 & 81 & 779 & 0.59\end{array}$

$\begin{array}{lllll}4 & 8.7 & 63 & 545 & 0.29\end{array}$

$\begin{array}{lllll}4 & 11.5 & 22 & 254 & 0.38\end{array}$

$\begin{array}{lllll}4 & 9.6 & 21 & 202 & 0.44\end{array}$

$\begin{array}{lcccc}4 & 9.6 & 21 & 202 & 0.44 \\ 4 & 11.5 & 34 & 393 & 0.88\end{array}$

$\begin{array}{lllll}4 & 9.6 & 40 & 385 & 0.59\end{array}$

$\begin{array}{lcccc}4 & 11.5 & 74 & 854 & 0.47\end{array}$

$\begin{array}{lllll}4 & 11.5 & 74 & 854 & 0.47 \\ 4 & 6.7 & 27 & 182 & 0.29\end{array}$

$\begin{array}{lllll}4 & 5.8 & 27 & 156 & 0.59\end{array}$

$\begin{array}{lllll}5 & 9.6 & 25 & 241 & 0.50\end{array}$

$\begin{array}{lllll}5 & 11.5 & 71 & 820 & 0.59\end{array}$

$\begin{array}{lllll}5 & 8.7 & 29 & 251 & 0.29\end{array}$

$\begin{array}{lllll}5 & 10.6 & 23 & 243 & 0.38\end{array}$

$\begin{array}{lllll}5 & 7.7 & 11 & 85 & 0.67\end{array}$

$\begin{array}{lllll}5 & 9.6 & 22 & 212 & 0.29\end{array}$

$\begin{array}{lllll}5 & 9.6 & 63 & 606 & 0.73\end{array}$

$\begin{array}{lllll}5 & 11.5 & 57 & 658 & 0.73\end{array}$

$\begin{array}{lllll}5 & 11.5 & 65 & 750 & 0.70\end{array}$

$\begin{array}{lllll}5 & 13.5 & 46 & 620 & 0.67\end{array}$

$\begin{array}{lllll}5 & 11.5 & 26 & 300 & 0.59\end{array}$

$\begin{array}{lllll}5 & 12.5 & 17 & 213 & 0.53\end{array}$

$\begin{array}{lllll}5 & 9.6 & 10 & 96 & 0.73\end{array}$

$\begin{array}{lllll}5 & 12.5 & 20 & 250 & 0.44\end{array}$

$\begin{array}{lllll}5 & 11.5 & 12 & 139 & 0.29\end{array}$

$\begin{array}{lllll}5 & 12.5 & 25 & 313 & 0.44\end{array}$

$\begin{array}{lllll}5 & 10.6 & 17 & 180 & 0.65\end{array}$

$\begin{array}{lllll}5 & 15.4 & 45 & 693 & 0.35\end{array}$

$\begin{array}{lllll}5 & 12.5 & 27 & 338 & 0.47\end{array}$

$\begin{array}{lllll}5 & 15.4 & 49 & 754 & 0.38\end{array}$

$\begin{array}{lllll}5 & 14.4 & 25 & 361 & 0.59\end{array}$

$\begin{array}{lllll}5 & 15.4 & 25 & 385 & 0.29\end{array}$

$\begin{array}{lllll}5 & 12.5 & 52 & 650 & 0.35\end{array}$

$\begin{array}{lllll}5 & 15.4 & 75 & 1154 & 0.53\end{array}$

$\begin{array}{lllll}5 & 13.5 & 66 & 889 & 0.59\end{array}$

$\begin{array}{lllll}5 & 9.6 & 12 & 115 & 0.47\end{array}$

$\begin{array}{lllll}5 & 11.5 & 51 & 589 & 0.59\end{array}$

$\begin{array}{lllll}5 & 9.6 & 112 & 1077 & 0.44\end{array}$

$\begin{array}{lllll}5 & 16.4 & 76 & 1243 & 0.70\end{array}$

$\begin{array}{lllll}5 & 20.2 & 30 & 606 & 0.38\end{array}$

$\begin{array}{lllll}5 & 15.4 & 93 & 1432 & 0.65\end{array}$

$\begin{array}{lllll}5 & 17.3 & 39 & 675 & 0.41\end{array}$

$\begin{array}{lllll}5 & 14.4 & 77 & 1111 & 0.59\end{array}$ 


\begin{tabular}{|c|c|c|c|c|c|c|c|}
\hline 45 & $\lg \mathrm{RCCa}$ & 1906 & 5 & 13.5 & 107 & 1441 & 0.82 \\
\hline 46 & $\lg r$ & 2013 & 5 & 15.4 & 52 & 800 & 0.29 \\
\hline 47 & $\lg \mathrm{RCCa}$ & 2065 & 5 & 14.4 & 146 & 2107 & 0.59 \\
\hline 48 & Gld & 2211 & 5 & 24.1 & 117 & 2814 & 0.29 \\
\hline 49 & $\lg r$ & 2328 & 5 & 25.0 & 25 & 625 & 0.29 \\
\hline 50 & $\operatorname{lgrRCa}$ & 2353 & 5 & 15.4 & 41 & 631 & 0.53 \\
\hline 51 & $\lg r$ & 2394 & 5 & 12.5 & 35 & 438 & 0.53 \\
\hline 52 & $\lg \mathrm{RCa}$ & 2429 & 5 & 16.4 & 84 & 1374 & 0.59 \\
\hline 53 & $\lg r$ & 2513 & 5 & 15.4 & 44 & 677 & 0.44 \\
\hline 54 & Gld & 2557 & 5 & 14.4 & 19 & 274 & 0.44 \\
\hline 55 & Lgr & 2576 & 5 & 14.4 & 8 & 115 & 0.29 \\
\hline 56 & Gld & 2584 & 5 & 13.5 & 10 & 135 & 0.53 \\
\hline 57 & $\operatorname{lgr}$ & 2594 & 5 & 15.4 & 69 & 1062 & 0.59 \\
\hline 58 & $\lg \mathrm{RCCa}$ & 2663 & 5 & 13.5 & 32 & 431 & 0.82 \\
\hline 59 & Gld & 2695 & 5 & 19.2 & 59 & 1135 & 0.44 \\
\hline 60 & $\lg r$ & 2754 & 5 & 21.2 & 49 & 1037 & 0.53 \\
\hline 61 & $\lg r \mathrm{RCa}$ & 2803 & 5 & 13.5 & 71 & 956 & 0.76 \\
\hline 62 & $\mathrm{Hgr}$ & 2874 & 5 & 14.4 & 32 & 462 & 0.59 \\
\hline 63 & $\mathrm{BPCa}$ & 2906 & 5 & 14.4 & 51 & 736 & 1.17 \\
\hline 64 & $\operatorname{lgrRCa}$ & 2957 & 5 & 16.4 & 196 & 3205 & 0.67 \\
\hline 65 & $\lg r$ & 3153 & 5 & 17.3 & 55 & 952 & 0.59 \\
\hline 66 & Hlgr & 3208 & 5 & 15.4 & 54 & 831 & 0.44 \\
\hline 67 & $\mathrm{BPCa}$ & 3262 & 5 & 13.5 & 45 & 606 & 1.32 \\
\hline 68 & Gld & 3307 & 5 & 14.4 & 26 & 375 & 0.82 \\
\hline 69 & $\lg \mathrm{RCa}$ & 3333 & 5 & 16.4 & 135 & 2208 & 0.79 \\
\hline 70 & $\lg r$ & 3468 & 5 & 17.3 & 33 & 571 & 0.50 \\
\hline 71 & GLd & 3501 & 5 & 17.3 & 48 & 831 & 0.59 \\
\hline 72 & $\lg r$ & 3549 & 5 & 18.3 & 93 & 1700 & 0.50 \\
\hline 73 & $\lg \mathrm{RCa}$ & 3642 & 5 & 16.4 & 95 & 1554 & 0.79 \\
\hline 74 & $\operatorname{lgr}$ & 3737 & 5 & 17.3 & 73 & 1264 & 0.59 \\
\hline 75 & $\mathrm{BPCa}$ & 3810 & 5 & 15.4 & 36 & 554 & 0.88 \\
\hline 76 & Gld & 3846 & 5 & 22.1 & 68 & 1505 & 0.29 \\
\hline 77 & ILgr & 3914 & 5 & 15.4 & 62 & 954 & 0.67 \\
\hline 78 & $\operatorname{lgrRCb}$ & 3976 & 5 & 13.5 & 110 & 1482 & 0.79 \\
\hline 79 & $\operatorname{lgrRCa}$ & 4086 & 6 & 16.4 & 154 & 2519 & 1.32 \\
\hline 80 & $\operatorname{lgrRCa}$ & 4240 & 6 & 25.0 & 55 & 1376 & 0.79 \\
\hline 81 & ILgr & 4295 & 6 & 22.1 & 15 & 332 & 0.59 \\
\hline 82 & IgrRCa & 4310 & 6 & 16.4 & 24 & 393 & 0.88 \\
\hline 83 & $\lg r$ & 4334 & 6 & 21.2 & 26 & 550 & 0.62 \\
\hline 84 & IgrRCa & 4360 & 6 & 15.4 & 46 & 708 & 1.00 \\
\hline 85 & lgr & 4406 & 6 & 21.2 & 99 & 2095 & 0.51 \\
\hline 86 & Gld & 4505 & 6 & 22.1 & 110 & 2434 & 0.59 \\
\hline 87 & $\operatorname{lgr}$ & 4615 & 6 & 21.2 & 23 & 487 & 0.51 \\
\hline 88 & $\lg \mathrm{RCa}$ & 4638 & 6 & 19.2 & 87 & 1674 & 0.59 \\
\hline 89 & Lgr & 4725 & 6 & 22.1 & 35 & 774 & 0.44 \\
\hline 90 & $\operatorname{IgrRCa}$ & 4760 & 6 & 17.3 & 41 & 710 & 0.73 \\
\hline 91 & $\lg r$ & 4801 & 6 & 20.2 & 38 & 768 & 0.44 \\
\hline 92 & IgrRCa & 4839 & 6 & 14.4 & 44 & 635 & 0.97 \\
\hline 93 & $\lg r$ & 4883 & 6 & 17.3 & 10 & 173 & 0.47 \\
\hline 94 & $\mathrm{Hgr}$ & 4893 & 6 & 14.4 & 27 & 390 & 0.73 \\
\hline
\end{tabular}




\begin{tabular}{|c|c|c|c|c|c|c|c|}
\hline 95 & $\mathrm{BPCa}$ & 4920 & 6 & 18.3 & 107 & 1956 & 0.67 \\
\hline 96 & Gld & 5027 & 6 & 22.1 & 29 & 642 & 0.50 \\
\hline 97 & Lgr & 5056 & 6 & 24.1 & 64 & 1539 & 0.29 \\
\hline 98 & $\lg r$ & 5120 & 6 & 19.2 & 20 & 385 & 0.29 \\
\hline 99 & $\mathrm{BPCa}$ & 5140 & 6 & 21.2 & 82 & 1736 & 0.67 \\
\hline 100 & $\operatorname{Lgr}$ & 5222 & 6 & 26.0 & 79 & 2052 & 0.29 \\
\hline 101 & $\lg r$ & 5301 & 6 & 24.1 & 15 & 361 & 0.29 \\
\hline 102 & $\lg \mathrm{RCa}$ & 5316 & 6 & 22.1 & 19 & 420 & 0.66 \\
\hline 103 & $\lg r$ & 5335 & 6 & 18.3 & 13 & 238 & 0.29 \\
\hline 104 & $\lg r$ & 5348 & 6 & 13.5 & 8 & 108 & 0.73 \\
\hline 105 & $\mathrm{BPCa}$ & 5356 & 6 & 12.5 & 75 & 938 & 1.03 \\
\hline 106 & $\mathrm{Hgr}$ & 5431 & 6 & 12.5 & 10 & 125 & 0.59 \\
\hline 107 & $\mathrm{BPCa}$ & 5441 & 6 & 14.4 & 27 & 390 & 0.88 \\
\hline 108 & LgrGldCa & 5468 & 6 & 14.4 & 38 & 548 & 0.73 \\
\hline 109 & $\lg \mathrm{RCa}$ & 5506 & 6 & 13.5 & 135 & 1818 & 0.67 \\
\hline 110 & LgrGldCa & 5641 & 6 & 12.5 & 44 & 550 & 0.67 \\
\hline 111 & $\lg r$ & 5685 & 6 & 11.5 & 44 & 508 & 0.73 \\
\hline 112 & Gld & 5729 & 6 & 14.4 & 68 & 981 & 0.82 \\
\hline 113 & $\mathrm{BPCb}$ & 5797 & 6 & 11.5 & 25 & 289 & 0.88 \\
\hline 114 & Gld & 5822 & 6 & 14.4 & 29 & 418 & 0.67 \\
\hline 115 & $\lg r$ & 5851 & 6 & 16.4 & 46 & 752 & 0.29 \\
\hline 116 & $\lg r \mathrm{RCa}$ & 5897 & 6 & 12.5 & 48 & 600 & 0.59 \\
\hline 117 & Gld & 5945 & 6 & 9.6 & 35 & 337 & 0.50 \\
\hline 118 & $\mathrm{BPCa}$ & 5980 & 6 & 11.5 & 76 & 877 & 0.82 \\
\hline 119 & LgrGldCa & 6056 & 6 & 15.4 & 66 & 1016 & 0.67 \\
\hline 120 & $\lg r$ & 6122 & 6 & 9.6 & 54 & 519 & 0.73 \\
\hline 121 & Gld & 6176 & 6 & 13.5 & 46 & 620 & 0.38 \\
\hline 122 & $\operatorname{lgrRCa}$ & 6222 & 6 & 11.5 & 74 & 854 & 0.82 \\
\hline 123 & Gld & 6296 & 6 & 12.5 & 28 & 350 & 0.82 \\
\hline 124 & $\lg r \mathrm{RCa}$ & 6324 & 6 & 9.6 & 74 & 712 & 0.67 \\
\hline 125 & Gld & 6398 & 6 & 15.4 & 40 & 616 & 0.73 \\
\hline 126 & Lgr & 6438 & 6 & 12.5 & 44 & 550 & 0.50 \\
\hline 127 & LgrGldCa & 6482 & 6 & 13.5 & 30 & 404 & 0.53 \\
\hline 128 & $\mathrm{BPCa}$ & 6512 & 6 & 9.6 & 110 & 1058 & 0.82 \\
\hline 129 & LgrRCa & 6622 & 6 & 15.4 & 38 & 585 & 0.67 \\
\hline 130 & LgrRCa & 6660 & 6 & 17.3 & 101 & 1749 & 0.53 \\
\hline 131 & $\lg r$ & 6761 & 6 & 16.4 & 37 & 605 & 0.44 \\
\hline 132 & LgrRCa & 6798 & 6 & 14.4 & 68 & 981 & 0.82 \\
\hline 133 & $\mathrm{BPCa}$ & 6866 & 6 & 12.5 & 34 & 425 & 0.88 \\
\hline 134 & Gld & 6900 & 6 & 15.4 & 17 & 262 & 0.73 \\
\hline 135 & LgrGldCa & 6917 & 6 & 16.4 & 45 & 736 & 0.44 \\
\hline 136 & $\lg r$ & 6962 & 6 & 14.4 & 50 & 722 & 0.56 \\
\hline 137 & LgrRCa & 7012 & 6 & 15.4 & 62 & 954 & 0.59 \\
\hline 138 & $\lg r$ & 7074 & 6 & 13.5 & 71 & 956 & 0.29 \\
\hline 139 & Gld & 7145 & 6 & 15.4 & 52 & 800 & 0.35 \\
\hline 140 & LgrRCa & 7197 & 6 & 11.5 & 46 & 531 & 0.73 \\
\hline 141 & Gld & 7243 & 6 & 13.5 & 84 & 1131 & 0.53 \\
\hline 142 & $\operatorname{lgrRCa}$ & 7327 & 6 & 26.9 & 58 & 1562 & 0.73 \\
\hline 143 & Lgr & 7385 & 6 & 14.4 & 51 & 736 & 0.35 \\
\hline 144 & Gld & 7436 & 6 & 13.5 & 71 & 956 & 0.47 \\
\hline
\end{tabular}




\begin{tabular}{|c|c|c|c|c|c|c|c|}
\hline 145 & $\lg \mathrm{RCa}$ & 7507 & 6 & 11.5 & 65 & 750 & 0.73 \\
\hline 146 & LgrGldCa & 7572 & 6 & 14.4 & 95 & 1371 & 0.29 \\
\hline 147 & $\lg r$ & 7667 & 6 & 9.6 & 30 & 289 & 0.29 \\
\hline 148 & LgrGldCa & 7697 & 6 & 24.1 & 31 & 746 & 0.29 \\
\hline 149 & $\mathrm{BPCb}$ & 7728 & 6 & 15.4 & 38 & 585 & 1.17 \\
\hline 150 & $\operatorname{lgrRCa}$ & 7766 & 6 & 13.5 & 66 & 889 & 0.82 \\
\hline 151 & Gld & 7832 & 6 & 13.5 & 46 & 620 & 0.82 \\
\hline 152 & LgrRCa & 7878 & 6 & 15.4 & 87 & 1339 & 0.59 \\
\hline 153 & IgrRCa & 7965 & 6 & 13.5 & 71 & 956 & 0.82 \\
\hline 154 & Gld & 8036 & 6 & 19.2 & 62 & 1193 & 0.47 \\
\hline 155 & LgrRCa & 8098 & 6 & 15.4 & 42 & 646 & 0.73 \\
\hline 156 & Gld & 8140 & 6 & 24.1 & 246 & 5917 & 0.29 \\
\hline 157 & Lgr & 8386 & 7 & 9.6 & 44 & 423 & 0.67 \\
\hline 158 & Gld & 8430 & 7 & 16.4 & 80 & 1308 & 0.44 \\
\hline 159 & $\lg r$ & 8510 & 7 & 15.4 & 42 & 646 & 0.38 \\
\hline 160 & Gld & 8552 & 7 & 16.4 & 61 & 998 & 1.03 \\
\hline 161 & LgrGldCa & 8613 & 7 & 17.3 & 102 & 1766 & 0.59 \\
\hline 162 & $\operatorname{lgrRCa}$ & 8715 & 7 & 9.6 & 136 & 1308 & 0.82 \\
\hline 163 & LgrGldCa & 8851 & 7 & 16.4 & 79 & 1292 & 0.44 \\
\hline 164 & $\lg r$ & 8930 & 7 & 13.5 & 33 & 444 & 0.38 \\
\hline 165 & Gld & 8963 & 7 & 16.4 & 57 & 932 & 0.59 \\
\hline 166 & Lgr & 9020 & 7 & 15.4 & 34 & 523 & 0.59 \\
\hline 167 & Gld & 9054 & 7 & 18.3 & 69 & 1261 & 0.73 \\
\hline 168 & $\lg r$ & 9123 & 7 & 17.3 & 34 & 589 & 0.38 \\
\hline 169 & LgrGldCa & 9157 & 7 & 16.4 & 29 & 474 & 0.35 \\
\hline 170 & $\lg r$ & 9186 & 7 & 16.4 & 33 & 540 & 0.44 \\
\hline 171 & $\mathrm{BPCa}$ & 9219 & 7 & 14.4 & 117 & 1688 & 0.82 \\
\hline 172 & Gld & 9336 & 7 & 25.0 & 230 & 5753 & 0.82 \\
\hline 173 & $\lg r$ & 9566 & 7 & 11.5 & 86 & 993 & 0.35 \\
\hline 174 & LgrGldCa & 9652 & 7 & 16.4 & 83 & 1357 & 0.44 \\
\hline 175 & $\mathrm{BPCa}$ & 9735 & 7 & 14.4 & 110 & 1587 & 0.59 \\
\hline 176 & $\lg \mathrm{RCa}$ & 9845 & 7 & 15.4 & 80 & 1231 & 0.79 \\
\hline 177 & LgrRCa & 9925 & 7 & 14.4 & 38 & 548 & 0.73 \\
\hline 178 & IgrRCa & 9963 & 7 & 15.4 & 123 & 1893 & 0.88 \\
\hline 179 & $\mathrm{HgrRCa}$ & 10086 & 7 & 14.4 & 45 & 649 & 1.17 \\
\hline 180 & LgrRCa & 10131 & 7 & 14.4 & 14 & 202 & 0.73 \\
\hline 181 & $\lg r$ & 10145 & 7 & 16.4 & 123 & 2012 & 0.53 \\
\hline 182 & Gld & 10268 & 7 & 21.2 & 53 & 1122 & 0.88 \\
\hline 183 & $\mathrm{BPCa}$ & 10321 & 7 & 9.6 & 44 & 423 & 0.88 \\
\hline 184 & Gld & 10365 & 7 & 15.4 & 31 & 477 & 0.73 \\
\hline 185 & $\lg r$ & 10396 & 7 & 21.2 & 59 & 1249 & 0.35 \\
\hline 186 & Gld & 10455 & 7 & 19.2 & 58 & 1116 & 0.53 \\
\hline 187 & $\lg \mathrm{RCa}$ & 10513 & 7 & 7.7 & 94 & 723 & 0.73 \\
\hline 188 & Gld & 10607 & 7 & 17.3 & 137 & 2372 & 0.38 \\
\hline 189 & $\lg r$ & 10744 & 7 & 19.2 & 38 & 731 & 0.47 \\
\hline 190 & $\lg \mathrm{RCa}$ & 10782 & 7 & 17.3 & 67 & 1160 & 0.73 \\
\hline 191 & Gld & 10849 & 7 & 18.3 & 148 & 2705 & 0.79 \\
\hline 192 & LgrGldCa & 10997 & 7 & 19.2 & 38 & 731 & 0.44 \\
\hline 193 & $\lg \mathrm{RCa}$ & 11035 & 7 & 15.4 & 75 & 1154 & 0.73 \\
\hline 194 & Gld & 11110 & 7 & 16.4 & 22 & 360 & 0.44 \\
\hline
\end{tabular}




\begin{tabular}{|c|c|c|c|c|c|c|c|}
\hline 195 & $\lg \mathrm{RCa}$ & 11132 & 7 & 15.4 & 123 & 1893 & 0.59 \\
\hline 196 & $\lg r$ & 11255 & 7 & 15.4 & 21 & 323 & 0.53 \\
\hline 197 & Gld & 11276 & 7 & 17.3 & 46 & 797 & 0.47 \\
\hline 198 & $\lg r$ & 11322 & 7 & 16.4 & 56 & 916 & 0.50 \\
\hline 199 & Gld & 11378 & 7 & 16.4 & 49 & 801 & 0.29 \\
\hline 200 & $\lg \mathrm{RCa}$ & 11427 & 7 & 16.4 & 101 & 1652 & 0.73 \\
\hline 201 & Gld & 11528 & 7 & 17.3 & 21 & 364 & 0.41 \\
\hline 202 & $\lg r$ & 11549 & 7 & 15.4 & 20 & 308 & 0.35 \\
\hline 203 & Gld & 11569 & 7 & 16.4 & 20 & 327 & 0.29 \\
\hline 204 & LgrGldC & 11589 & 7 & 17.3 & 64 & 1108 & 0.29 \\
\hline 205 & $\mathrm{IHgr}$ & 11653 & 7 & 15.4 & 51 & 785 & 0.29 \\
\hline 206 & Pool & 11704 & 7 & 2.8 & 14 & 40 & 0.73 \\
\hline 207 & Gld & 11718 & 7 & 15.4 & 66 & 1016 & 0.44 \\
\hline 208 & $\lg \mathrm{RCCa}$ & 11784 & 7 & 14.4 & 28 & 404 & 0.73 \\
\hline 209 & Gld & 11812 & 7 & 14.4 & 23 & 332 & 0.67 \\
\hline 210 & $\mathrm{Hgr}$ & 11835 & 7 & 17.3 & 35 & 606 & 0.29 \\
\hline 211 & Gld & 11870 & 7 & 15.4 & 49 & 754 & 0.44 \\
\hline 212 & Lgr & 11919 & 7 & 13.5 & 37 & 498 & 0.38 \\
\hline 213 & Gld & 11956 & 7 & 18.3 & 59 & 1078 & 0.44 \\
\hline 214 & Lgr & 12015 & 7 & 13.5 & 16 & 215 & 0.44 \\
\hline 215 & Gld & 12031 & 7 & 14.4 & 48 & 693 & 0.59 \\
\hline 216 & $\lg r$ & 12079 & 7 & 14.4 & 24 & 346 & 0.47 \\
\hline 217 & Gld & 12103 & 7 & 16.4 & 23 & 376 & 0.53 \\
\hline 218 & Lgr & 12126 & 7 & 15.4 & 39 & 600 & 0.41 \\
\hline 219 & Gld & 12165 & 7 & 16.4 & 40 & 654 & 0.53 \\
\hline 220 & $\lg r$ & 12205 & 8 & 15.4 & 47 & 723 & 0.67 \\
\hline 221 & Gld & 12252 & 8 & 16.4 & 45 & 736 & 0.53 \\
\hline 222 & $\lg \mathrm{RCCa}$ & 12297 & 8 & 17.3 & 50 & 866 & 0.88 \\
\hline 223 & Gld & 12347 & 8 & 15.4 & 41 & 631 & 0.67 \\
\hline 224 & Ihgr & 12388 & 8 & 17.3 & 61 & 1056 & 0.38 \\
\hline 225 & Pool & 12449 & 8 & 13.5 & 23 & 310 & 1.03 \\
\hline 226 & Gld & 12472 & 8 & 17.3 & 33 & 571 & 0.44 \\
\hline 227 & $\mathrm{IHgr}$ & 12505 & 8 & 11.5 & 33 & 381 & 0.53 \\
\hline 228 & $\lg r \mathrm{RCa}$ & 12538 & 8 & 15.4 & 86 & 1324 & 0.73 \\
\hline 229 & Gld & 12624 & 8 & 17.3 & 146 & 2528 & 0.44 \\
\hline 230 & $\lg \mathrm{RCa}$ & 12770 & 8 & 17.3 & 16 & 277 & 0.44 \\
\hline 231 & Gld & 12786 & 8 & 17.3 & 39 & 675 & 0.41 \\
\hline 232 & $\lg \mathrm{RCa}$ & 12825 & 8 & 14.4 & 85 & 1227 & 0.59 \\
\hline 233 & Pool/backwater/lagoon & 12910 & 8 & 6.7 & 13 & 88 & 0.38 \\
\hline 234 & $\mathrm{BPCa}$ & 12923 & 8 & 15.4 & 200 & 3079 & 0.73 \\
\hline 235 & Gld & 13123 & 8 & 22.1 & 19 & 420 & 0.38 \\
\hline 236 & $\mathrm{Hgr}$ & 13142 & 8 & 12.5 & 29 & 363 & 0.59 \\
\hline 237 & $\operatorname{lgrRCb}$ & 13171 & 8 & 16.4 & 48 & 785 & 0.73 \\
\hline 238 & $\mathrm{BPCa}$ & 13219 & 8 & 17.3 & 79 & 1368 & 0.65 \\
\hline 239 & Gld & 13298 & 8 & 21.2 & 22 & 466 & 0.50 \\
\hline 240 & $\mathrm{BPCa}$ & 13320 & 8 & 15.4 & 150 & 2309 & 0.88 \\
\hline 241 & $\lg \mathrm{RCCa}$ & 13470 & 8 & 16.4 & 50 & 818 & 0.73 \\
\hline 242 & $\lg r$ & 13520 & 8 & 16.4 & 30 & 491 & 0.44 \\
\hline 243 & $\lg \mathrm{RCb}$ & 13550 & 8 & 16.4 & 107 & 1750 & 0.82 \\
\hline 244 & Pool & 13657 & 8 & 19.2 & 49 & 943 & 1.17 \\
\hline
\end{tabular}




\begin{tabular}{|c|c|c|c|c|c|c|c|}
\hline 245 & $\mathrm{BPCa}$ & 13706 & 8 & 15.4 & 90 & 1385 & 0.82 \\
\hline 246 & LgrRCa & 13796 & 8 & 26.0 & 120 & 3117 & 0.35 \\
\hline 247 & Gld & 13916 & 8 & 17.3 & 40 & 693 & 0.44 \\
\hline 248 & Ihgr & 13956 & 8 & 18.3 & 39 & 713 & 0.29 \\
\hline 249 & $\mathrm{BPCa}$ & 13995 & 8 & 18.3 & 51 & 932 & 0.79 \\
\hline 250 & $\lg r$ & 14046 & 8 & 14.4 & 24 & 346 & 0.59 \\
\hline 251 & Gld & 14070 & 8 & 17.3 & 77 & 1333 & 0.59 \\
\hline 252 & $\mathrm{BPCa}$ & 14147 & 9 & 14.4 & 52 & 750 & 0.88 \\
\hline 253 & Gld & 14199 & 9 & 18.3 & 64 & 1170 & 0.65 \\
\hline 254 & $\lg r$ & 14263 & 9 & 17.3 & 73 & 1264 & 0.59 \\
\hline 255 & Pool & 14336 & 9 & 21.2 & 74 & 1566 & 0.94 \\
\hline 256 & Gld & 14410 & 9 & 19.2 & 18 & 346 & 0.82 \\
\hline 257 & $\lg r$ & 14428 & 9 & 18.3 & 23 & 420 & 0.35 \\
\hline 258 & Gld & 14451 & 9 & 19.2 & 35 & 673 & 0.50 \\
\hline 259 & Lgr & 14486 & 9 & 17.3 & 37 & 641 & 0.29 \\
\hline 260 & $\lg \mathrm{RCb}$ & 14523 & 9 & 13.5 & 123 & 1657 & 1.03 \\
\hline 261 & $\mathrm{Hgr}$ & 14646 & 9 & 16.4 & 62 & 1014 & 0.38 \\
\hline 262 & $\lg \mathrm{RCa}$ & 14708 & 9 & 16.4 & 75 & 1227 & 0.59 \\
\hline 263 & Gld & 14783 & 9 & 19.2 & 25 & 481 & 0.35 \\
\hline 264 & $\lg r$ & 14808 & 9 & 18.3 & 31 & 567 & 0.29 \\
\hline 265 & $\operatorname{lgrRCa}$ & 14839 & 9 & 15.4 & 38 & 585 & 1.03 \\
\hline 266 & $\lg r$ & 14877 & 9 & 17.3 & 30 & 519 & 0.44 \\
\hline 267 & $\lg r R C a$ & 14907 & 9 & 28.9 & 42 & 1212 & 0.67 \\
\hline 268 & $\lg r$ & 14949 & 9 & 17.3 & 17 & 294 & 0.44 \\
\hline 269 & $\lg r R C a$ & 14966 & 9 & 15.4 & 34 & 523 & 0.67 \\
\hline 270 & Gld & 15000 & 9 & 18.3 & 34 & 621 & 0.44 \\
\hline 271 & $\lg r$ & 15034 & 9 & 17.3 & 34 & 589 & 0.41 \\
\hline 272 & $\operatorname{lgrRCa}$ & 15068 & 9 & 15.4 & 46 & 708 & 0.70 \\
\hline 273 & $\lg r$ & 15114 & 9 & 17.3 & 62 & 1074 & 0.38 \\
\hline 274 & $\lg r R C a$ & 15176 & 9 & 17.3 & 58 & 1004 & 0.73 \\
\hline 275 & Pool & 15234 & 9 & 22.1 & 20 & 443 & 1.03 \\
\hline 276 & Gld & 15254 & 9 & 20.2 & 30 & 606 & 0.59 \\
\hline 277 & $\lg r$ & 15284 & 9 & 18.3 & 26 & 475 & 0.29 \\
\hline 278 & Gld & 15310 & 9 & 18.3 & 12 & 219 & 0.44 \\
\hline 279 & $\lg r$ & 15322 & 9 & 17.3 & 22 & 381 & 0.38 \\
\hline 280 & Gld & 15344 & 9 & 17.3 & 17 & 294 & 0.44 \\
\hline 281 & $\lg r$ & 15361 & 9 & 17.3 & 16 & 277 & 0.38 \\
\hline 282 & $\lg r R C a$ & 15377 & 9 & 14.4 & 67 & 967 & 0.88 \\
\hline 283 & Gld & 15444 & 9 & 18.3 & 40 & 731 & 0.47 \\
\hline 284 & IHgr & 15484 & 9 & 16.4 & 20 & 327 & 0.44 \\
\hline 285 & $\lg \mathrm{RCa}$ & 15504 & 9 & 15.4 & 91 & 1401 & 0.82 \\
\hline 286 & Gld/Pool & 15595 & 9 & 20.2 & 206 & 4162 & 0.59 \\
\hline 287 & $\operatorname{lgrRCb}$ & 15801 & 9 & 33.7 & 47 & 1583 & 0.59 \\
\hline 288 & Pool & 15848 & 9 & 4.8 & 10.1 & 49 & 0.88 \\
\hline 289 & $\lg r$ & 15858 & 9 & 13.5 & 92 & 1239 & 0.44 \\
\hline 290 & $\lg \mathrm{RCa}$ & 15950 & 9 & 12.5 & 43 & 538 & 0.59 \\
\hline 291 & $\lg r$ & 15993 & 9 & 13.5 & 21 & 283 & 0.44 \\
\hline 292 & Gld & 16014 & 9 & 15.4 & 38 & 585 & 0.38 \\
\hline 293 & Lgr & 16052 & 9 & 14.4 & 24 & 346 & 0.47 \\
\hline 294 & Gld & 16076 & 9 & 18.3 & 22 & 402 & 0.59 \\
\hline
\end{tabular}




\begin{tabular}{|c|c|c|c|c|c|c|c|}
\hline 295 & LgrRCa & 16098 & 9 & 15.4 & 30 & 462 & 0.59 \\
\hline 296 & Gld & 16128 & 9 & 16.4 & 36 & 589 & 0.56 \\
\hline 297 & LgrRCa & 16164 & 9 & 15.4 & 16 & 246 & 0.59 \\
\hline 298 & $\lg r$ & 16180 & 9 & 17.3 & 73 & 1264 & 0.44 \\
\hline 299 & HgrRa & 16253 & 9 & 12.5 & 33 & 413 & 0.73 \\
\hline 300 & $\lg r$ & 16286 & 10 & 9.6 & 56 & 539 & 0.29 \\
\hline 301 & $\mathrm{BPCa}$ & 16342 & 10 & 14.4 & 55 & 794 & 0.88 \\
\hline 302 & Gld (mostly) & 16397 & 10 & 14.4 & 23 & 332 & 0.88 \\
\hline 303 & ILgrRCa & 16420 & 10 & 15.4 & 163 & 2509 & 0.67 \\
\hline 304 & HgrRCa & 16583 & 10 & 9.6 & 63 & 606 & 1.11 \\
\hline 305 & Gld & 16646 & 10 & 17.3 & 51 & 883 & 0.59 \\
\hline 306 & $\lg r$ & 16697 & 10 & 25.0 & 69 & 1726 & 0.53 \\
\hline 307 & $\lg r \mathrm{RCa}$ & 16766 & 10 & 14.4 & 21 & 303 & 0.82 \\
\hline 308 & Lgr & 16787 & 10 & 14.4 & 30 & 433 & 0.50 \\
\hline 309 & Gld & 16817 & 10 & 16.4 & 28 & 458 & 0.59 \\
\hline 310 & $\mathrm{IHgr}$ & 16845 & 10 & 15.4 & 24 & 369 & 0.29 \\
\hline 311 & Gld & 16869 & 10 & 13.5 & 64 & 862 & 0.53 \\
\hline 312 & $\lg r$ & 16933 & 10 & 15.4 & 68 & 1047 & 0.59 \\
\hline 313 & Gld & 17001 & 10 & 19.2 & 237 & 4560 & 0.44 \\
\hline 314 & $\operatorname{IgrRCa}$ & 17238 & 10 & 28.9 & 137 & 3954 & 0.53 \\
\hline 315 & Lgr & 17375 & 10 & 14.4 & 102 & 1472 & 0.59 \\
\hline 316 & $\lg \mathrm{RCa}$ & 17477 & 10 & 13.5 & 36 & 485 & 0.82 \\
\hline 317 & Gld & 17513 & 10 & 15.4 & 59 & 908 & 0.53 \\
\hline 318 & $\lg r$ & 17572 & 10 & 11.5 & 18 & 208 & 0.29 \\
\hline 319 & Gld & 17590 & 10 & 17.3 & 59 & 1022 & 0.44 \\
\hline 320 & $\lg r$ & 17649 & 10 & 14.4 & 22 & 317 & 0.29 \\
\hline 321 & Gld & 17671 & 10 & 17.3 & 198 & 3429 & 0.38 \\
\hline 322 & $\operatorname{lgrRCa}$ & 17869 & 10 & 9.6 & 56 & 539 & 0.73 \\
\hline 323 & Gld & 17925 & 10 & 17.3 & 29 & 502 & 0.73 \\
\hline 324 & $\lg \mathrm{RCa}$ & 17954 & 10 & 13.5 & 59 & 795 & 0.73 \\
\hline 325 & $\lg r$ & 18013 & 10 & 17.3 & 61 & 1056 & 0.53 \\
\hline 326 & LgrGldCa & 18074 & 10 & 15.4 & 188 & 2894 & 0.73 \\
\hline 327 & Gld & 18262 & 10 & 18.3 & 117 & 2139 & 0.47 \\
\hline 328 & $\lg r$ & 18379 & 10 & 14.4 & 36 & 519 & 0.35 \\
\hline 329 & Gld & 18415 & 10 & 16.4 & 115 & 1881 & 0.53 \\
\hline 330 & HgrRCa & 18530 & 10 & 11.5 & 133 & 1535 & 0.73 \\
\hline 331 & Gld & 18663 & 10 & 16.4 & 77 & 1259 & 0.53 \\
\hline 332 & $\mathrm{IHgr}$ & 18740 & 10 & 13.5 & 18 & 242 & 0.29 \\
\hline 333 & Gld & 18758 & 10 & 19.2 & 118 & 2270 & 0.59 \\
\hline 334 & $\operatorname{lgrRCb}$ & 18876 & 10 & 14.4 & 133 & 1919 & 0.70 \\
\hline 335 & Gld & 19009 & 10 & 16.4 & 135 & 2208 & 0.59 \\
\hline 336 & ILgr & 19144 & 10 & 16.4 & 152 & 2486 & 0.59 \\
\hline 337 & Gld & 19296 & 10 & 20.2 & 100 & 2020 & 0.67 \\
\hline 338 & $\lg r$ & 19396 & 11 & 16.4 & 58 & 949 & 0.59 \\
\hline 339 & Gld & 19454 & 11 & 28.9 & 129 & 3723 & 0.73 \\
\hline 340 & $\lg r$ & 19583 & 11 & 16.4 & 33 & 540 & 0.59 \\
\hline 341 & $\mathrm{BPCb}$ & 19616 & 11 & 22.1 & 50 & 1106 & 1.03 \\
\hline 342 & $\operatorname{lgrRCa}$ & 19666 & 11 & 15.4 & 144 & 2217 & 0.82 \\
\hline 343 & LgrGldCa & 19810 & 11 & 25.0 & 157 & 3927 & 0.59 \\
\hline 344 & $\lg r$ & 19967 & 11 & 38.5 & 87 & 3348 & 0.59 \\
\hline
\end{tabular}




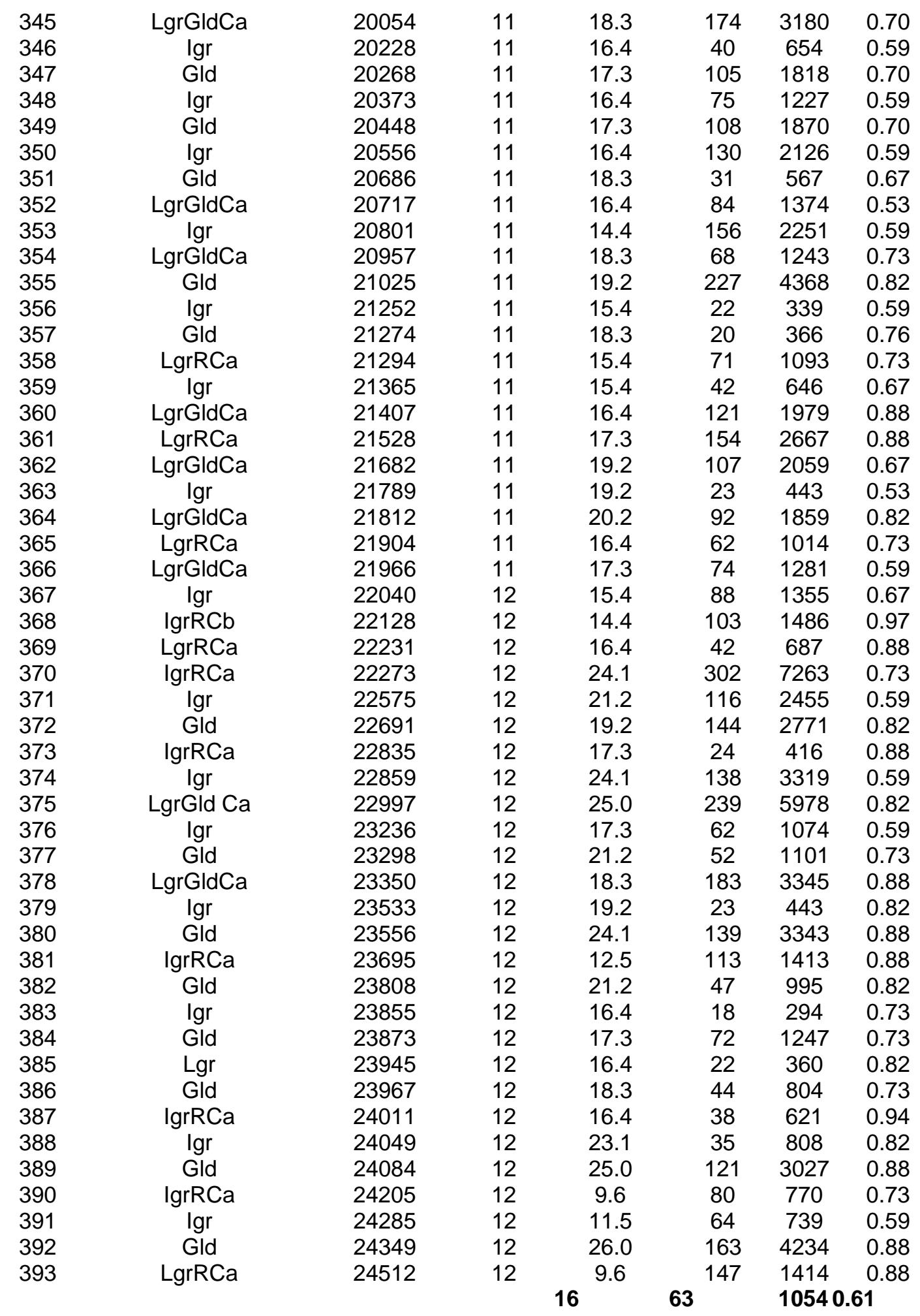




\section{Appendix II}

\section{Large Woody Debris (LWD) Data}

\begin{tabular}{|c|c|c|c|c|c|c|c|c|c|c|c|}
\hline $\begin{array}{c}\text { Channel } \\
\text { Unit \# }\end{array}$ & Channel Unit & $\begin{array}{c}\text { Distance } \\
\text { Downstream } \\
\text { From Spruce } \\
\text { (m) }\end{array}$ & $\begin{array}{l}\text { Stream } \\
\text { Segment }\end{array}$ & $\begin{array}{l}\text { LWD } \\
\text { short/ } \\
\text { skinny }\end{array}$ & $\begin{array}{c}\text { LWD } \\
\text { short/ } \\
\text { medium }\end{array}$ & $\begin{array}{c}\text { LWD } \\
\text { short/ } \\
\text { fat }\end{array}$ & $\begin{array}{l}\text { LWD } \\
\text { long/ } \\
\text { skinny }\end{array}$ & $\begin{array}{c}\text { LWD } \\
\text { long/ } \\
\text { medium }\end{array}$ & $\begin{array}{l}\text { LWD } \\
\text { long/ } \\
\text { fat }\end{array}$ & $\begin{array}{l}\text { Relative } \\
\text { Volume of } \\
\text { LWD }\end{array}$ & $\begin{array}{l}\text { Rootwads } \\
\text { and other } \\
\text { LWD }\end{array}$ \\
\hline 1 & Gld & 0 & 4 & 1 & & & & & & 1 & exposed \\
\hline 2 & $\operatorname{IgrRCa}$ & 55 & 4 & 1 & & 5 & 5 & & & 6 & exposed \\
\hline 3 & Debris & 124 & 4 & 1 & & & 2 & 4 & 6 & 13 & \\
\hline 4 & $\lg r$ & 205 & 4 & 1 & & & & & 12 & 21 & ${ }^{*}(8 / 3 / 2)$ \\
\hline 5 & Gld & 268 & 4 & 1 & & & & & 12 & 21 & \\
\hline 6 & $\operatorname{lgrRCa}$ & 290 & 4 & 1 & & & 2 & ? & & 3 & ${ }^{*} r r-d e b r i s$ \\
\hline 7 & BPRCb & 311 & 4 & 1 & 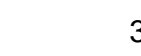 & 3 & 5 & & & 9 & ${ }^{*}$ rr-debris \\
\hline 8 & $\operatorname{lgrRCa}$ & 345 & 4 & 1 & & & & & 6 & 11 & ${ }^{*}$ rr-debris \\
\hline 9 & Gld & 385 & 4 & 2 & & & & & & 2 & \\
\hline 10 & IHgr & 459 & 4 & & & & 5 & & & 5 & \\
\hline 11 & $\lg \mathrm{RCa}$ & 486 & 4 & & & & & & 12 & 20 & $*(3 / 2 / 3)$ \\
\hline 12 & $\mathrm{IHgr}$ & 513 & 5 & 1 & & & & & & 1 & \\
\hline 13 & BPRCa & 538 & 5 & & & & & $\varepsilon$ & 12 & 20 & $*(1 / 1 / 1)$ \\
\hline 14 & $\operatorname{lgr}$ & 609 & 5 & 1 & & & & & & 1 & ${ }^{*}(\mathrm{sml})$ \\
\hline 15 & Gld & 638 & 5 & 1 & & & & & & 1 & \\
\hline 16 & $\lg \mathrm{RCa}$ & 661 & 5 & & 3 & 3 & & & & 3 & \\
\hline 17 & Gld & 672 & 5 & 1 & & & & & & 1 & \\
\hline 18 & $\lg \mathrm{RCa}$ & 694 & 5 & 1 & & & & & & 1 & ${ }^{*}(8 / 5 / 5)$ \\
\hline 19 & BPRCa & 757 & 5 & & 6 & 6 & & & & 6 & \\
\hline 20 & $\operatorname{lgrRCa}$ & 814 & 5 & 1 & & & & & & 1 & \\
\hline 21 & Gld & 879 & 5 & & & & 5 & & & 5 & \\
\hline 22 & $\lg \mathrm{RCa}$ & 925 & 5 & 1 & & & 5 & & & 6 & \\
\hline 23 & $\lg r$ & 951 & 5 & & & & 2 & $\varepsilon$ & 8 & 10 & \\
\hline 24 & $\lg \mathrm{RCa}$ & 968 & 5 & & 3 & 3 & & & & 3 & \\
\hline 25 & Gld & 978 & 5 & 1 & & & & & & 1 & \\
\hline 26 & Lgr & 998 & 5 & & & & & & & 0 & ${ }^{*}(\mathrm{sml})$ \\
\hline 27 & Gld & 1010 & 5 & 1 & & & & & & 1 & \\
\hline 28 & $\operatorname{lgrRCa}$ & 1035 & 5 & & & & & 4 & 6 & 10 & ${ }^{*}(2 / 2 / 4)$ \\
\hline 29 & Gld & 1052 & 5 & 1 & & & & & & 1 & \\
\hline 30 & Lgr & 1097 & 5 & 1 & 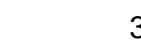 & 3 & 2 & ? & & 6 & \\
\hline 31 & Gld & 1124 & 5 & & 6 & 6 & & & & 6 & \\
\hline 32 & $\lg \mathrm{RCCa}$ & 1173 & 5 & 1 & & 10 & 0 & 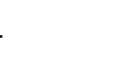 & & 15 & \\
\hline 33 & Gld & 1198 & 5 & 1 & & & & & & 1 & \\
\hline 34 & $\lg r$ & 1223 & 5 & 1 & 3 & 3 & 2 & ? & & 6 & ${ }^{*}(\mathrm{sml})$ \\
\hline 35 & Gld & 1275 & 5 & & 3 & 3 & & & & 3 & \\
\hline 36 & $\lg \mathrm{RCa}$ & 1350 & 5 & & 3 & 3 & & & & 3 & \\
\hline 37 & $\lg r$ & 1416 & 5 & & & 5 & 5 & ? & & 7 & \\
\hline 38 & IgrRCa & 1428 & 5 & 1 & & & 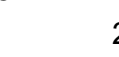 & ? & & 3 & \\
\hline 39 & BPRCa & 1479 & 5 & 1 & 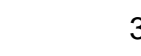 & 3 & 2 & 4 & 4 & 10 & \\
\hline 40 & $\lg r R C a$ & 1591 & 5 & & & & & 4 & 4 & 4 & ${ }^{*}(2 / 1 / 1)$ \\
\hline 41 & $\lg r$ & 1667 & 5 & & & & 2 & 4 & 4 & 8 & ${ }^{*}(6 / 3 / 2)$ \\
\hline 42 & $\lg r R C a$ & 1697 & 5 & & & & & 4 & 4 & 4 & \\
\hline 43 & Lgr & 1790 & 5 & & 6 & 6 & & & & 6 & \\
\hline 44 & $\mathrm{IHgr}$ & 1829 & 5 & & 3 & 3 & 2 & ? & & 5 & \\
\hline 45 & $\operatorname{lgrRCa}$ & 1906 & 5 & & & & 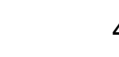 & 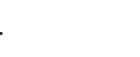 & & 4 & \\
\hline 46 & $\lg r$ & 2013 & 5 & & 3 & 3 & & & 12 & 15 & \\
\hline 47 & $\lg r R C a$ & 2065 & 5 & 1 & & & 2 & 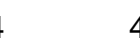 & 18 & 27 & ${ }^{*}(1 / 1 / 1)$ \\
\hline
\end{tabular}




\begin{tabular}{|c|c|c|c|c|c|c|c|c|c|c|c|}
\hline 48 & Gld & 2211 & 5 & & & & 4 & & & 4 & \\
\hline 49 & $\lg r$ & 2328 & 5 & & 3 & & & & & 3 & \\
\hline 50 & $\lg r \mathrm{RCa}$ & 2353 & 5 & & 3 & & & & & 3 & * \\
\hline 51 & $\lg r$ & 2394 & 5 & & & 5 & & & 12 & 17 & \\
\hline 52 & $\lg \mathrm{RCa}$ & 2429 & 5 & & & & 4 & & 6 & 10 & \\
\hline 53 & $\lg r$ & 2513 & 5 & 1 & & & 2 & & & 3 & \\
\hline 54 & Gld & 2557 & 5 & 1 & & & & & & 1 & \\
\hline 57 & $\lg r$ & 2594 & 5 & 1 & & & 2 & & & 3 & \\
\hline 58 & $\lg r \mathrm{RCa}$ & 2663 & 5 & 1 & 6 & & & & 18 & 25 & \\
\hline 59 & Gld & 2695 & 5 & 1 & 3 & 5 & 2 & & 18 & 29 & ${ }^{*}(3 / 3 / 5)$ \\
\hline 60 & $\lg r$ & 2754 & 5 & & & & & 4 & 6 & 10 & ${ }^{*}(4 / 2 / 2)$ \\
\hline 65 & $\lg r$ & 3153 & 5 & 1 & & & & & 6 & 7 & \\
\hline 66 & Hlgr & 3208 & 5 & 1 & & & & & & 1 & \\
\hline 67 & BPRCa & 3262 & 5 & 1 & & & & & & 1 & ${ }^{*}(4 / 3 / 2)$ \\
\hline 68 & Gld & 3307 & 5 & 1 & 3 & & & & 6 & 10 & \\
\hline 69 & $\lg r \mathrm{RCa}$ & 3333 & 5 & 1 & & & & & 6 & 7 & ${ }^{*}(3 / 2 / 2)$ \\
\hline 70 & $\lg r$ & 3468 & 5 & 1 & 6 & & & & & 7 & * \\
\hline 71 & GLd & 3501 & 5 & 1 & & & & & & 1 & \\
\hline 72 & $\lg r$ & 3549 & 5 & & & & 2 & & & 2 & \\
\hline 73 & $\lg \mathrm{rRCa}$ & 3642 & 5 & & & & & 8 & 6 & 14 & \\
\hline 81 & ILgr & 4295 & 6 & & & & & & 6 & 6 & \\
\hline 82 & $\lg \mathrm{RCa}$ & 4310 & 6 & 1 & 6 & 5 & & & 6 & 18 & \\
\hline 83 & $\lg r$ & 4334 & 6 & 1 & & & & 4 & 6 & 11 & \\
\hline 84 & $\lg \mathrm{RCa}$ & 4360 & 6 & 1 & & 5 & & & & 6 & \\
\hline 85 & $\lg r$ & 4406 & 6 & 1 & & & & & & 1 & ${ }^{*}(4 / 2 / 2)$ \\
\hline 86 & Gld & 4505 & 6 & & & & & 4 & 6 & 10 & ${ }^{*}(4 / 3 / 1)$ \\
\hline 87 & $\lg r$ & 4615 & 6 & 1 & 3 & & & & & 4 & \\
\hline 88 & $\lg r \mathrm{RCa}$ & 4638 & 6 & 1 & & & 2 & & & 3 & \\
\hline 89 & Lgr & 4725 & 6 & & & & 2 & & & 2 & \\
\hline 90 & $\lg r \mathrm{RCa}$ & 4760 & 6 & 1 & 6 & & & & & 7 & \\
\hline 91 & $\lg r$ & 4801 & 6 & & 3 & & & & & 3 & \\
\hline 92 & $\lg \mathrm{RCa}$ & 4839 & 6 & & & & 2 & 4 & 6 & 12 & ${ }^{*}(10 / 3 / 2)$ \\
\hline 93 & $\lg r$ & 4883 & 6 & & & & 4 & & & 4 & ${ }^{*}(5 / 3 / 2)$ \\
\hline 94 & $\mathrm{Hgr}$ & 4893 & 6 & 1 & & & & & & 1 & \\
\hline 95 & BPRCa & 4920 & 6 & & & & 2 & & & 2 & \\
\hline 96 & Gld & 5027 & 6 & & & & & & & 0 & \\
\hline 97 & Lgr & 5056 & 6 & & & & & & & 0 & \\
\hline 98 & $\lg r$ & 5120 & 6 & & & & 4 & & & 4 & ${ }^{*} \mathrm{rw}(4 / 3 / 2)$ \\
\hline 99 & BPRCa & 5140 & 6 & & & & & & & 0 & \\
\hline
\end{tabular}




\begin{tabular}{|c|c|c|c|c|c|c|c|c|c|c|c|}
\hline 103 & $\lg r$ & 5335 & 6 & & & & & & & 0 & \\
\hline 104 & $\operatorname{lgr}$ & 5348 & 6 & & & & 2 & & 6 & 8 & ${ }^{*}(4 / 3 / 2)$ \\
\hline 105 & BPRCa & 5356 & 6 & & & & & & & 0 & \\
\hline 106 & $\mathrm{Hgr}$ & 5431 & 6 & & & & & & & 0 & \\
\hline 107 & BPRCa & 5441 & 6 & & & & & & & 0 & \\
\hline 108 & LgrGldCa & 5468 & 6 & 1 & & & & & & 1 & \\
\hline 109 & $\operatorname{lgrRCa}$ & 5506 & 6 & 1 & 3 & & 2 & 4 & 6 & 16 & \\
\hline 110 & LgrGldCa & 5641 & 6 & 1 & & & & & & 1 & \\
\hline 111 & $\lg r$ & 5685 & 6 & 1 & 3 & 5 & 2 & & & 11 & \\
\hline 112 & Gld & 5729 & 6 & & & & & & & 0 & \\
\hline 113 & BPRCb & 5797 & 6 & & & 10 & & & & 10 & \\
\hline 114 & Gld & 5822 & 6 & & 3 & 5 & 2 & & 6 & 16 & \\
\hline 115 & $\lg r$ & 5851 & 6 & & 3 & & 2 & & 6 & 11 & \\
\hline 116 & $\lg R \mathrm{RCa}$ & 5897 & 6 & 1 & 3 & 5 & & 4 & & 13 & \\
\hline 117 & Gld & 5945 & 6 & 1 & & & & & & 1 & \\
\hline 118 & BPRCa & 5980 & 6 & 1 & & & & 4 & & 5 & \\
\hline 119 & LgrGldCa & 6056 & 6 & 1 & & & & & & 1 & \\
\hline 120 & $\lg r$ & 6122 & 6 & 1 & & 10 & & & & 11 & \\
\hline 121 & Gld & 6176 & 6 & & 3 & & & & & 3 & \\
\hline 122 & $\lg \mathrm{RCa}$ & 6222 & 6 & 1 & & & & & & 1 & \\
\hline 123 & Gld & 6296 & 6 & 1 & & & & 4 & & 5 & ${ }^{*}(2 / 2 / 2)$ \\
\hline 124 & $\lg \mathrm{RCa}$ & 6324 & 6 & 1 & & & & & & 1 & \\
\hline 125 & Gld & 6398 & 6 & & 3 & & & & & 3 & \\
\hline 126 & Lgr & 6438 & 6 & 1 & & 5 & & 4 & & 10 & ${ }^{\star *}(\mathrm{sml})$ \\
\hline 127 & LgrGldCa & 6482 & 6 & 1 & 3 & & 2 & 8 & & 14 & ${ }^{* \star}(3 / 3 / 5)$ \\
\hline 128 & BPRCa & 6512 & 6 & 1 & & & & & & 1 & \\
\hline 129 & LgrRCa & 6622 & 6 & 1 & 3 & & & & & 4 & \\
\hline 130 & LgrRCa & 6660 & 6 & 1 & & & & & & 1 & \\
\hline 131 & $\lg r$ & 6761 & 6 & 1 & & & & & 6 & 7 & \\
\hline 132 & LgrRCa & 6798 & 6 & 1 & 3 & 5 & 2 & & & 11 & ${ }^{*}(3 / 5 / 2)$ \\
\hline 133 & BPRCa & 6866 & 6 & 1 & & & & & & 1 & \\
\hline 134 & Gld & 6900 & 6 & 1 & & & 2 & & & 3 & \\
\hline 135 & LgrGldCa & 6917 & 6 & 1 & & & & & & 1 & \\
\hline 136 & $\lg r$ & 6962 & 6 & 1 & 3 & & & & & 4 & \\
\hline 137 & LgrRCa & 7012 & 6 & 1 & & 5 & & & 6 & 12 & ${ }^{*}$ rr-tie \\
\hline 138 & $\lg r$ & 7074 & 6 & 1 & & & & & & 1 & \\
\hline 139 & Gld & 7145 & 6 & 1 & & & 2 & & & 3 & \\
\hline 140 & LgrRCa & 7197 & 6 & 1 & & & & & 6 & 7 & \\
\hline 141 & Gld & 7243 & 6 & 1 & 3 & 5 & 2 & 4 & 6 & 21 & ${ }^{*} 2 x^{\prime} s$ \\
\hline 142 & $\lg \mathrm{RCa}$ & 7327 & 6 & 1 & 3 & & 2 & & & 6 & \\
\hline 143 & Lgr & 7385 & 6 & 1 & 3 & 5 & 2 & 4 & 6 & 21 & ${ }^{*} 3 / 5 / 8$ \\
\hline 144 & Gld & 7436 & 6 & 1 & 3 & & & & & 4 & \\
\hline 145 & $\operatorname{lgrRCa}$ & 7507 & 6 & & & & & & & 0 & \\
\hline 146 & LgrGldCa & 7572 & 6 & & & & & 4 & 6 & 10 & \\
\hline 147 & $\lg r$ & 7667 & 6 & 1 & & & & & & 1 & \\
\hline 148 & LgrGldCa & 7697 & 6 & & 3 & 5 & & & 6 & 14 & \\
\hline 149 & BPRCb & 7728 & 6 & 1 & 3 & 5 & & & & 9 & \\
\hline 150 & $\lg \mathrm{RCa}$ & 7766 & 6 & & & 5 & & & & 5 & \\
\hline 151 & Gld & 7832 & 6 & 1 & 3 & 5 & 2 & & & 11 & \\
\hline 152 & LgrRCa & 7878 & 6 & 1 & & 5 & 2 & & & 8 & ${ }^{*} 15 / 8 / 3$ \\
\hline 153 & $\lg \mathrm{RCa}$ & 7965 & 6 & 1 & 3 & 5 & 2 & 4 & 6 & 21 & \\
\hline 154 & Gld & 8036 & 6 & & & & & & 6 & 6 & \\
\hline 155 & LgrRCa & 8098 & 6 & 1 & & 5 & & & & 6 & \\
\hline 156 & Gld & 8140 & 6 & 1 & 3 & 5 & 4 & 4 & 6 & 23 & $\begin{array}{r}\text { *in-stream } \\
\text { debris }\end{array}$ \\
\hline
\end{tabular}




\begin{tabular}{|c|c|c|c|c|c|c|c|c|c|c|c|}
\hline 157 & Lgr & 8386 & 7 & 1 & & & & & & 1 & ${ }^{*} 1 / 3 / 2$ \\
\hline 158 & Gld & 8430 & 7 & 1 & 3 & & 2 & 8 & & 14 & \\
\hline 159 & $\lg r$ & 8510 & 7 & & & 5 & 2 & 4 & & 11 & \\
\hline 160 & Gld & 8552 & 7 & 1 & & 5 & 2 & & & 8 & \\
\hline 161 & LgrGldCa & 8613 & 7 & 1 & 3 & & & & & 4 & \\
\hline 162 & $\lg \mathrm{RCa}$ & 8715 & 7 & 1 & 3 & & 2 & & & 6 & \\
\hline 163 & LgrGldCa & 8851 & 7 & 1 & 3 & & 2 & 8 & & 14 & ${ }^{*} 2 x^{\prime} s$ at Ift. \\
\hline 164 & $\lg r$ & 8930 & 7 & & & & 2 & & & 2 & \\
\hline 165 & Gld & 8963 & 7 & 1 & & & 2 & & & 3 & \\
\hline 166 & Lgr & 9020 & 7 & 1 & & & & & & 1 & \\
\hline 167 & Gld & 9054 & 7 & 1 & & & & & & 1 & \\
\hline 168 & $\lg r$ & 9123 & 7 & 1 & & 5 & & 4 & & 10 & *(1/3/2) \\
\hline 169 & LgrGldCa & 9157 & 7 & 1 & 3 & 10 & & & 12 & 26 & ${ }^{*} \mathrm{rw}$ \\
\hline 170 & $\lg r$ & 9186 & 7 & 1 & & & 2 & & & 3 & \\
\hline 171 & BPRCa & 9219 & 7 & 1 & & & 2 & & & 3 & \\
\hline 172 & Gld & 9336 & 7 & 1 & 3 & 5 & & 4 & 6 & 19 & \\
\hline 173 & $\lg r$ & 9566 & 7 & 1 & & & & & 6 & 7 & ${ }^{\star}(\mathrm{sml})$ \\
\hline 174 & LgrGldCa & 9652 & 7 & 1 & 3 & 5 & 2 & 4 & 12 & 27 & ${ }^{*} r w$ \\
\hline 175 & BPRCa & 9735 & 7 & 1 & 3 & & & & & 4 & \\
\hline 176 & $\lg r \mathrm{RCa}$ & 9845 & 7 & 1 & 3 & 5 & 2 & 4 & 12 & 27 & ${ }^{*}(25 / 5 / 5)$ \\
\hline 177 & LgrRCa & 9925 & 7 & 1 & & 5 & & & 6 & 12 & \\
\hline 178 & $\lg r \mathrm{RCa}$ & 9963 & 7 & & 6 & & 2 & & & 8 & \\
\hline 179 & $\mathrm{HgrRCa}$ & 10086 & 7 & 1 & 3 & 5 & 4 & 4 & 6 & 23 & *(vry Irg) \\
\hline 180 & LgrRCa & 10131 & 7 & & & & 2 & & 6 & 8 & * $(25 / 5 / 3)$ \\
\hline 181 & $\lg r$ & 10145 & 7 & & & 5 & 2 & 4 & 12 & 23 & * $(25 / 5 / 3)$ \\
\hline 182 & Gld & 10268 & 7 & & & & & & 6 & 6 & \\
\hline 183 & BPRCa & 10321 & 7 & 1 & 3 & 5 & & & & 9 & \\
\hline 184 & Gld & 10365 & 7 & 1 & & & & & & 1 & \\
\hline 185 & $\lg r$ & 10396 & 7 & & & & 2 & & 6 & 8 & \\
\hline 186 & Gld & 10455 & 7 & 1 & & & 2 & & & 3 & \\
\hline 187 & $\lg \mathrm{RCa}$ & 10513 & 7 & 1 & 3 & & 2 & 4 & & 10 & \\
\hline 188 & Gld & 10607 & 7 & 1 & & & & & & 1 & ${ }^{*}(\mathrm{sml})$ \\
\hline 189 & $\lg r$ & 10744 & 7 & 1 & 3 & & 4 & & & 8 & \\
\hline 190 & $\lg \mathrm{RCa}$ & 10782 & 7 & & & & & & 12 & 12 & \\
\hline 191 & Gld & 10849 & 7 & 1 & 3 & & 2 & & 6 & 12 & ${ }^{*}(1 / 2 / 3)$ \\
\hline 192 & LgrGldCa & 10997 & 7 & 1 & & 5 & & & & 6 & \\
\hline 193 & $\lg r \mathrm{RCa}$ & 11035 & 7 & 1 & 3 & 5 & 2 & 4 & 6 & 21 & ${ }^{\star *}(4 / 4 / 15)$ \\
\hline 194 & Gld & 11110 & 7 & & & & & & & 0 & \\
\hline 195 & $\lg \mathrm{RCa}$ & 11132 & 7 & & & & & 4 & & 4 & \\
\hline 196 & $\lg r$ & 11255 & 7 & 1 & & & 2 & & & 3 & \\
\hline 197 & Gld & 11276 & 7 & 1 & 3 & 5 & 2 & 4 & 6 & 21 & ${ }^{*}$ rw at rt. \\
\hline 198 & $\lg r$ & 11322 & 7 & & 3 & & & & & 3 & \\
\hline 199 & Gld & 11378 & 7 & 1 & & & & & & 1 & \\
\hline 200 & $\lg \mathrm{RCa}$ & 11427 & 7 & 1 & & & 2 & & & 3 & \\
\hline 201 & Gld & 11528 & 7 & 1 & & & & & & 1 & \\
\hline 202 & $\lg r$ & 11549 & 7 & 1 & & & & & & 1 & \\
\hline 203 & Gld & 11569 & 7 & & & & 2 & & & 2 & \\
\hline 204 & LgrGldC & 11589 & 7 & 1 & & & 2 & & & 3 & \\
\hline 205 & IHgr & 11653 & 7 & 1 & 3 & & & & & 4 & \\
\hline 206 & Pool & 11704 & 7 & 2 & 6 & & & & & 8 & \\
\hline 207 & Gld & 11718 & 7 & & & & & & & 0 & \\
\hline 208 & $\lg r \mathrm{RCa}$ & 11784 & 7 & 1 & & & & & & 1 & \\
\hline 209 & Gld & 11812 & 7 & 1 & & & & & & 1 & \\
\hline 210 & $\mathrm{Hgr}$ & 11835 & 7 & 1 & & & & & & 1 & \\
\hline 211 & Gld & 11870 & 7 & & & & & & & 0 & \\
\hline
\end{tabular}




\begin{tabular}{|c|c|c|c|c|c|c|c|c|c|c|c|}
\hline & & & & & & & & & & & *(vry Irg) at \\
\hline 212 & Lgr & 11919 & 7 & 1 & 3 & 5 & 2 & 4 & 6 & 21 & rt. \\
\hline 213 & Gld & 11956 & 7 & 1 & & & & & & 1 & \\
\hline 214 & Lgr & 12015 & 7 & 1 & & & & & & 1 & \\
\hline 215 & Gld & 12031 & 7 & 1 & 3 & 5 & 2 & 4 & 6 & 21 & * \\
\hline 216 & $\lg r$ & 12079 & 7 & 1 & 3 & & & & & 4 & \\
\hline 217 & Gld & 12103 & 7 & & 3 & & 2 & 8 & 12 & 25 & ${ }^{*}(3 / 2 / 5)$ \\
\hline 218 & Lgr & 12126 & 7 & & & & 4 & & & 4 & \\
\hline 219 & Gld & 12165 & 7 & 1 & 3 & & & & & 4 & \\
\hline 220 & $\lg r$ & 12205 & 8 & & & & 2 & & & 2 & \\
\hline 221 & Gld & 12252 & 8 & & & & & & & 0 & \\
\hline 222 & $\lg \mathrm{RCa}$ & 12297 & 8 & 1 & 3 & 5 & 2 & 4 & 12 & 27 & \\
\hline 223 & Gld & 12347 & 8 & & 3 & & & & & 3 & ${ }^{*} \mathrm{rw}$ \\
\hline 224 & Ihgr & 12388 & 8 & 1 & 3 & & & & & 4 & \\
\hline 225 & Pool & 12449 & 8 & 1 & 3 & 5 & 2 & & 6 & 17 & \\
\hline 226 & Gld & 12472 & 8 & & 3 & & & & & 3 & \\
\hline 227 & IHgr & 12505 & 8 & & & & & & & 0 & ${ }^{* *}(5 / 3 / 2)$ \\
\hline 228 & $\lg \mathrm{RCa}$ & 12538 & 8 & & & & & & & 0 & ${ }^{*}(\operatorname{Irg})$ \\
\hline 229 & Gld & 12624 & 8 & 1 & 3 & & & & & 4 & \\
\hline 230 & $\lg \mathrm{RCa}$ & 12770 & 8 & 1 & 3 & 5 & & & & 9 & \\
\hline 231 & Gld & 12786 & 8 & & 3 & & & & & 3 & $*(1 / 2 / 2)$ \\
\hline 232 & $\lg \mathrm{RCa}$ & 12825 & 8 & 1 & 3 & 5 & 2 & 4 & 18 & 33 & \\
\hline & Pool/backwater/lago & & & & & & & & & & ${ }^{*}$ rw(very \\
\hline 233 & on & 12910 & 8 & 1 & 6 & & & & & 7 & large) \\
\hline 234 & BPRCa & 12923 & 8 & 1 & & & 2 & & & 3 & \\
\hline 235 & Gld & 13123 & 8 & 1 & & & 2 & & & 3 & $*(4 / 2 / 3)$ \\
\hline 236 & $\mathrm{Hgr}$ & 13142 & 8 & 1 & & & 2 & & & 3 & \\
\hline 237 & $\lg \mathrm{RCb}$ & 13171 & 8 & & 3 & & & & & 3 & \\
\hline 238 & $\mathrm{BPRCa}$ & 13219 & 8 & 1 & & & & & 6 & 7 & \\
\hline 239 & Gld & 13298 & 8 & 1 & & & & & & 1 & \\
\hline 240 & BPRCa & 13320 & 8 & & & 5 & 2 & 4 & & 11 & \\
\hline 241 & $\lg \mathrm{RCa}$ & 13470 & 8 & 1 & & & 2 & & & 3 & \\
\hline 242 & $\lg r$ & 13520 & 8 & 1 & 3 & & & & & 4 & ${ }^{*}(2 / 2 / 3)$ \\
\hline 243 & $\lg \mathrm{RCb}$ & 13550 & 8 & 1 & & 5 & & & 6 & 12 & ${ }^{*} \mathrm{rw}(\mathrm{sml})$ \\
\hline 244 & Pool & 13657 & 8 & & 3 & & 2 & & 12 & 17 & \\
\hline 245 & $\mathrm{BPRCa}$ & 13706 & 8 & & 3 & 5 & 2 & & 12 & 22 & *(1/1/2) \\
\hline 246 & LgrRCa & 13796 & 8 & & 3 & & & 4 & & 7 & $\begin{array}{l}\text { *good-fair } \\
\text { habitat }\end{array}$ \\
\hline 247 & Gld & 13916 & 8 & & 3 & & & & & 3 & * \\
\hline 248 & Ihgr & 13956 & 8 & 2 & & & & 4 & & 6 & \\
\hline 249 & BPRCa & 13995 & 8 & & 3 & & & & 6 & 9 & \\
\hline 250 & $\operatorname{lgr}$ & 14046 & 8 & 1 & 6 & 5 & 4 & 4 & & 20 & \\
\hline 251 & Gld & 14070 & 8 & 1 & & 5 & 2 & & & 8 & \\
\hline 252 & $\mathrm{BPRCa}$ & 14147 & 9 & 2 & & & 2 & & & 4 & \\
\hline 253 & Gld & 14199 & 9 & & & & 4 & & & 4 & \\
\hline 254 & $\lg r$ & 14263 & 9 & & & & 2 & & 6 & 8 & \\
\hline 255 & Pool & 14336 & 9 & 2 & & & & & 12 & 14 & ${ }^{*}(2 / 3 / 1)$ \\
\hline 256 & Gld & 14410 & 9 & & & 10 & & & 6 & 16 & $*(5 / 5 / 2)$ \\
\hline 257 & $\lg r$ & 14428 & 9 & & & & 2 & 4 & & 6 & \\
\hline 258 & Gld & 14451 & 9 & & & & & & & 0 & ${ }^{*} \mathrm{sml} \mathrm{rw}$ \\
\hline 259 & Lgr & 14486 & 9 & 1 & 6 & & & & & 7 & * \\
\hline 260 & $\operatorname{lgrRCb}$ & 14523 & 9 & 2 & 6 & 10 & 4 & 8 & 18 & 48 & ${ }^{* *}(20 / 5)$ \\
\hline 261 & $\mathrm{Hgr}$ & 14646 & 9 & & & & & & & 0 & \\
\hline 262 & $\lg \mathrm{RCa}$ & 14708 & 9 & 1 & & & & & & 1 & \\
\hline
\end{tabular}




\begin{tabular}{|c|c|c|c|c|c|c|c|c|c|c|c|}
\hline 263 & Gld & 14783 & 9 & 1 & & & & 4 & & 5 & \\
\hline 264 & $\operatorname{lgr}$ & 14808 & 9 & 1 & & & 2 & & 12 & 15 & \\
\hline 265 & $\lg r R C a$ & 14839 & 9 & 1 & 3 & & & 8 & & 12 & \\
\hline 266 & $\lg r$ & 14877 & 9 & 1 & & & & & 6 & 7 & \\
\hline 267 & $\lg \mathrm{RCa}$ & 14907 & 9 & & & & & & 12 & 12 & \\
\hline 268 & $\lg r$ & 14949 & 9 & & 3 & & & & & 3 & \\
\hline 269 & $\lg r R C a$ & 14966 & 9 & & & 5 & & & 6 & 11 & \\
\hline 270 & Gld & 15000 & 9 & 1 & & & & & & 1 & \\
\hline 271 & $\lg r$ & 15034 & 9 & 1 & & & 2 & & 6 & 9 & \\
\hline 272 & $\lg \mathrm{RCa}$ & 15068 & 9 & & & & 4 & & 6 & 10 & \\
\hline 273 & $\lg r$ & 15114 & 9 & 1 & & & & & & 1 & \\
\hline 274 & $\lg r \mathrm{RCa}$ & 15176 & 9 & & & 5 & & 4 & 12 & 21 & \\
\hline 275 & Pool & 15234 & 9 & 1 & 3 & & & & & 4 & \\
\hline 276 & Gld & 15254 & 9 & 1 & 3 & & 2 & & & 6 & ${ }^{*}$ rr tie \\
\hline 277 & $\lg r$ & 15284 & 9 & 1 & & & & & & 1 & \\
\hline 278 & Gld & 15310 & 9 & 1 & & & 2 & 4 & 6 & 13 & \\
\hline 279 & $\lg r$ & 15322 & 9 & & 3 & & & & & 3 & \\
\hline 280 & Gld & 15344 & 9 & & & & & & 6 & 6 & ${ }^{*} \mathrm{rw}$ sml \\
\hline 281 & $\lg r$ & 15361 & 9 & & 3 & & & & & 3 & \\
\hline 282 & $\lg \mathrm{RCa}$ & 15377 & 9 & 1 & 3 & & & & 6 & 10 & ${ }^{*}(8 / 3 / 2)$ \\
\hline 283 & Gld & 15444 & 9 & 1 & 3 & & 2 & & & 6 & \\
\hline 284 & $\mathrm{IHgr}$ & 15484 & 9 & 1 & & 5 & & & & 6 & \\
\hline 285 & $\operatorname{lgrRCa}$ & 15504 & 9 & 1 & 3 & & & & & 4 & \\
\hline 286 & Gld/Pool & 15595 & 9 & 1 & 3 & 5 & 2 & 4 & 6 & 21 & $\begin{array}{l}\text { *stick and } \\
\text { leaf patch }\end{array}$ \\
\hline & & & & & & & & & & & ${ }^{*} \mathrm{rr}$ tie and \\
\hline 287 & $\lg \mathrm{RCb}$ & 15801 & 9 & 1 & 3 & 5 & 2 & 4 & 6 & 21 & rw \\
\hline 288 & Pool & 15848 & 9 & 1 & 3 & 5 & 2 & 4 & 6 & 21 & $\begin{array}{l}{ }^{*} \text { multiple } \\
\text { rw }(8 / 6 / 2)\end{array}$ \\
\hline 289 & $\lg r$ & 15858 & 9 & & & & & 8 & 12 & 20 & \\
\hline 290 & $\lg \mathrm{RCa}$ & 15950 & 9 & & & & 2 & & & 2 & \\
\hline 291 & $\lg r$ & 15993 & 9 & 1 & & 5 & & 4 & 6 & 16 & ${ }^{*}(3 / 8 / 5)$ \\
\hline 292 & Gld & 16014 & 9 & & 3 & & 2 & & & 5 & \\
\hline 293 & Lgr & 16052 & 9 & & 3 & & 2 & & 18 & 23 & $*(4 / 6 / 4)$ \\
\hline 294 & Gld & 16076 & 9 & 1 & 3 & & & & & 4 & \\
\hline 295 & LgrRCa & 16098 & 9 & & & & 2 & & & 2 & \\
\hline 296 & Gld & 16128 & 9 & 1 & & & & & & 1 & \\
\hline & & & & & & & & & & & cool scour \\
\hline 297 & LgrRCa & 16164 & 9 & 1 & 3 & & 2 & & 6 & 12 & at Ift. \\
\hline 298 & $\operatorname{lgr}$ & 16180 & 9 & & & & & & & 0 & *(5/4/3) \\
\hline 299 & HgrRa & 16253 & 9 & 1 & & 5 & & & & 6 & \\
\hline 300 & $\lg r$ & 16286 & 10 & & & 5 & & & & 5 & ${ }^{* *}(3 / 5 / 6)$ \\
\hline 301 & BPRCa & 16342 & 10 & & & 10 & 2 & 8 & & 20 & ${ }^{*}(3 / 3 / 2)$ \\
\hline 302 & Gld (mostly) & 16397 & 10 & 1 & 3 & 5 & 2 & 4 & 18 & 33 & ${ }^{*}(\mathrm{big})$ \\
\hline 303 & ILgrRCa & 16420 & 10 & & & & 4 & & & 4 & ${ }^{*}(\mathrm{sml})$ \\
\hline 304 & HgrRCa & 16583 & 10 & & 3 & & & & & 3 & \\
\hline 305 & Gld & 16646 & 10 & 1 & 3 & & & & & 4 & \\
\hline 306 & $\lg r$ & 16697 & 10 & & & 5 & 6 & & & 11 & \\
\hline 307 & $\lg r \mathrm{RCa}$ & 16766 & 10 & 1 & & 10 & & & & 11 & ${ }^{*}(\mathrm{sml})$ \\
\hline 308 & Lgr & 16787 & 10 & 1 & & & & & & 1 & \\
\hline 309 & Gld & 16817 & 10 & & & & & & & 0 & \\
\hline 310 & IHgr & 16845 & 10 & 2 & 3 & & 2 & 4 & 12 & 23 & *(15/5/8) \\
\hline 311 & Gld & 16869 & 10 & 1 & & & & & & 1 & \\
\hline 312 & $\lg r$ & 16933 & 10 & & 3 & & 2 & & & 5 & \\
\hline 313 & Gld & 17001 & 10 & 1 & & 5 & & & & 6 & \\
\hline
\end{tabular}




\begin{tabular}{|c|c|c|c|c|c|c|c|c|c|c|c|}
\hline 314 & $\operatorname{lgrRCa}$ & 17238 & 10 & & & 5 & 2 & & 6 & \multicolumn{2}{|l|}{13} \\
\hline 315 & Lgr & 17375 & 10 & 1 & & & & & & \multicolumn{2}{|l|}{1} \\
\hline 316 & $\lg \mathrm{RCa}$ & 17477 & 10 & & & & & & & 0 & *(20/5/4) \\
\hline 317 & Gld & 17513 & 10 & 1 & 3 & 5 & & & 6 & 15 & *(at top) \\
\hline 318 & $\lg r$ & 17572 & 10 & & & & & & & \multicolumn{2}{|l|}{0} \\
\hline 319 & Gld & 17590 & 10 & 1 & & & & & & \multicolumn{2}{|r|}{ *3/5/3) } \\
\hline 320 & $\lg r$ & 17649 & 10 & & & & 2 & & & \multicolumn{2}{|r|}{$*(3 / 3 / 3)$} \\
\hline 321 & Gld & 17671 & 10 & 1 & 3 & 5 & 2 & 4 & 6 & 21 & *(5/3/3) \\
\hline 322 & $\operatorname{lgrRCa}$ & 17869 & 10 & & & & & & & \multicolumn{2}{|r|}{$\begin{array}{l}\text { decent } \\
\text { riparian }\end{array}$} \\
\hline 323 & Gld & 17925 & 10 & 1 & 3 & & & & & \multicolumn{2}{|l|}{4} \\
\hline 324 & $\lg \mathrm{RCa}$ & 17954 & 10 & & & & & & 6 & \multicolumn{2}{|l|}{6} \\
\hline 325 & $\lg r$ & 18013 & 10 & & 3 & 5 & 4 & & & \multicolumn{2}{|l|}{12} \\
\hline 326 & LgrGldCa & 18074 & 10 & & 3 & 5 & & & & \multicolumn{2}{|c|}{8} \\
\hline 327 & Gld & 18262 & 10 & 1 & 3 & 10 & & & & \multicolumn{2}{|l|}{14} \\
\hline 328 & $\lg r$ & 18379 & 10 & 1 & & & & 4 & & \multicolumn{2}{|l|}{5} \\
\hline 329 & Gld & 18415 & 10 & & 3 & 5 & & & & \multicolumn{2}{|c|}{$8{ }^{*}(\mathrm{sml}$ at $\mathrm{lft})}$. \\
\hline 330 & $\mathrm{HgrRCa}$ & 18530 & 10 & 1 & 3 & 5 & & 4 & 12 & \multicolumn{2}{|c|}{$\begin{array}{l}{ }^{*} \text { lots of back } \\
25 \text { water debris }\end{array}$} \\
\hline 331 & Gld & 18663 & 10 & 1 & 3 & & 2 & 4 & 12 & \multicolumn{2}{|c|}{6} \\
\hline 332 & $\mathrm{IHgr}$ & 18740 & 10 & 1 & 3 & 5 & 2 & & & \multicolumn{2}{|c|}{11} \\
\hline 333 & Gld & 18758 & 10 & 1 & 3 & 5 & & 4 & 6 & \multicolumn{2}{|r|}{${ }^{*}$ rr-tie } \\
\hline 334 & $\lg R C b$ & 18876 & 10 & 1 & & 5 & & & 12 & \multicolumn{2}{|c|}{$18 \quad \begin{array}{ll}* \text { good } \\
18 \text { debris }\end{array}$} \\
\hline 335 & Gld & 19009 & 10 & 1 & & & & & & 1 & \\
\hline 336 & ILgr & 19144 & 10 & & 3 & 10 & 2 & & & 15 & $\begin{array}{l}\text { *debris at } \\
\text { bottom rt. }\end{array}$ \\
\hline 337 & Gld & 19296 & 10 & 1 & & & & & & 1 & \\
\hline 338 & $\lg r$ & 19396 & 11 & 1 & 3 & & & 4 & 6 & 14 & \\
\hline 339 & Gld & 19454 & 11 & & & & & 4 & 6 & 10 & ${ }^{*}$ rr-tie \\
\hline 340 & $\lg r$ & 19583 & 11 & 1 & & & & 4 & 6 & 11 & \\
\hline 341 & BPRCb & 19616 & 11 & & & 5 & & & & 5 & ${ }^{*}$ (high)rt. \\
\hline 342 & $\lg \mathrm{RCCa}$ & 19666 & 11 & & 3 & & & & & 3 & \\
\hline & & & & & & & & & & & (at bottom \\
\hline 343 & LgrGldCa & 19810 & 11 & 1 & 3 & & & & & 4 & rt.) \\
\hline 344 & $\lg r$ & 19967 & 11 & & & & 4 & & & 4 & \\
\hline 345 & LgrGldCa & 20054 & 11 & 1 & 3 & 5 & & & & 9 & ${ }^{*}$ rr-tie \\
\hline 346 & $\lg r$ & 20228 & 11 & & 3 & & & & & 3 & \\
\hline 347 & Gld & 20268 & 11 & & & & & & & 0 & \\
\hline 348 & $\lg r$ & 20373 & 11 & 1 & & & & & & 1 & \\
\hline 349 & Gld & 20448 & 11 & 1 & & & & & & 1 & \\
\hline 350 & $\lg r$ & 20556 & 11 & 1 & & & & & & 1 & \\
\hline 351 & Gld & 20686 & 11 & 1 & & 5 & & 4 & & 10 & *(12/3/2) \\
\hline 352 & LgrGldCa & 20717 & 11 & 1 & 3 & & & & 6 & 10 & \\
\hline 353 & $\lg r$ & 20801 & 11 & 1 & & & & & & 1 & \\
\hline 354 & LgrGldCa & 20957 & 11 & 1 & 3 & & & & & 4 & ${ }^{*}(\mathrm{sml})$ \\
\hline 355 & Gld & 21025 & 11 & 1 & & & 4 & & & 5 & \\
\hline 356 & $\lg r$ & 21252 & 11 & & & & & & & 0 & \\
\hline 357 & Gld & 21274 & 11 & 1 & & & & & & 1 & \\
\hline 358 & LgrRCa & 21294 & 11 & 1 & & & & & & 1 & \\
\hline 359 & $\lg r$ & 21365 & 11 & 1 & & & & & & 1 & \\
\hline 360 & LgrGldCa & 21407 & 11 & 1 & & & 2 & & 6 & 9 & \\
\hline 361 & LgrRCa & 21528 & 11 & 1 & 6 & & & & & 7 & \\
\hline 362 & LgrGldCa & 21682 & 11 & & & & & & 12 & 12 & *(3/1/1) \\
\hline 363 & $\lg r$ & 21789 & 11 & & & & 2 & & & 2 & \\
\hline
\end{tabular}




\begin{tabular}{|c|c|c|c|c|c|c|c|c|c|c|c|}
\hline 364 & LgrGldCa & 21812 & 11 & 1 & 3 & & 2 & & & 6 & \\
\hline 365 & LgrRCa & 21904 & 11 & 1 & 3 & & & 4 & & 8 & \\
\hline 366 & LgrGldCa & 21966 & 11 & 1 & & & & & & 1 & \\
\hline 367 & $\lg r$ & 22040 & 12 & 1 & & & & & & 1 & \\
\hline 368 & $\lg R \mathrm{Rb}$ & 22128 & 12 & 1 & 3 & 5 & & & & 9 & \\
\hline 369 & LgrRCa & 22231 & 12 & 1 & 3 & 5 & 2 & 4 & 6 & 21 & $*(14 / 5 / 3)$ \\
\hline 370 & $\lg \mathrm{RRCa}$ & 22273 & 12 & 1 & 3 & 5 & & & & 9 & ${ }^{*}$ rr-tie \\
\hline 371 & $\lg r$ & 22575 & 12 & 1 & & & 2 & & & 3 & \\
\hline 372 & Gld & 22691 & 12 & 1 & 3 & 5 & 2 & 4 & 6 & 21 & ${ }^{*}(5 / 3 / 6)$ \\
\hline 373 & $\lg \mathrm{RCa}$ & 22835 & 12 & & 3 & 5 & 2 & 4 & 12 & 26 & \\
\hline 374 & $\lg r$ & 22859 & 12 & 1 & & & & & & 1 & \\
\hline 375 & LgrGld Ca & 22997 & 12 & & & & 2 & & & 2 & \\
\hline 376 & $\lg r$ & 23236 & 12 & & & & & 8 & 12 & 20 & ${ }^{* *}(3 / 3 / 4)$ \\
\hline 377 & Gld & 23298 & 12 & & 6 & & & 4 & & 10 & \\
\hline 378 & LgrGldCa & 23350 & 12 & 1 & 3 & & 2 & 4 & & 10 & ${ }^{*}(3 / 1 / 1)$ \\
\hline 379 & $\lg r$ & 23533 & 12 & 1 & & & & & & 1 & \\
\hline 380 & Gld & 23556 & 12 & & & & & & & 0 & \\
\hline 381 & $\lg \mathrm{RCa}$ & 23695 & 12 & & & & & & & 0 & \\
\hline 382 & Gld & 23808 & 12 & & & & & & 6 & 6 & *(3/2/2) \\
\hline 383 & $\lg r$ & 23855 & 12 & & & & & & & 0 & \\
\hline 384 & Gld & 23873 & 12 & & & & & & & 0 & \\
\hline 385 & Lgr & 23945 & 12 & & & & & & & 0 & \\
\hline 386 & Gld & 23967 & 12 & & & & & & & 0 & \\
\hline 387 & $\lg r \mathrm{RCa}$ & 24011 & 12 & 2 & 3 & & & & & 5 & \\
\hline 388 & $\lg r$ & 24049 & 12 & & & & & & & 0 & \\
\hline 389 & Gld & 24084 & 12 & & & & & & & 0 & \\
\hline 390 & $\operatorname{lgrRCa}$ & 24205 & 12 & & 3 & & & & & 3 & \\
\hline 391 & $\lg r$ & 24285 & 12 & & & & 2 & 8 & 6 & 16 & \\
\hline 392 & Gld & 24349 & 12 & 1 & 3 & 5 & 2 & 4 & 6 & 21 & \\
\hline \multirow[t]{2}{*}{393} & LgrRCa & 24512 & 12 & 1 & & & & & & 1 & *(3/3/2) \\
\hline & & & & & & & & & & 2926 & \\
\hline
\end{tabular}

